Portland State University

PDXScholar

Fall 1-1-2013

\title{
Public Space and Urban Life: A Spatial Ethnography of a Portland Plaza
}

Katrina Leigh Johnston

Portland State University

Follow this and additional works at: https://pdxscholar.library.pdx.edu/open_access_etds

Part of the Urban, Community and Regional Planning Commons, and the Urban Studies and Planning Commons

Let us know how access to this document benefits you.

\section{Recommended Citation}

Johnston, Katrina Leigh, "Public Space and Urban Life: A Spatial Ethnography of a Portland Plaza" (2013). Dissertations and Theses. Paper 624.

https://doi.org/10.15760/etd.624

This Thesis is brought to you for free and open access. It has been accepted for inclusion in Dissertations and Theses by an authorized administrator of PDXScholar. Please contact us if we can make this document more accessible: pdxscholar@pdx.edu. 
Public Space and Urban Life: A Spatial Ethnography of a Portland Plaza

by

Katrina Leigh Johnston

A thesis submitted in partial fulfillment of the requirements for the degree of

\author{
Master of Urban Studies \\ in \\ Urban Studies
}

\author{
Thesis Committee: \\ Ethan Seltzer, Chair \\ Carl Abbott \\ Hunter Shobe
}

Portland State University

2012 
C2012 Katrina Leigh Johnston 


\section{Abstract}

The Urban Center Plaza at Portland State University is a high profile place situated in downtown Portland, Oregon. In some ways it is the ideal university plaza providing space for eating, conversing, or limited recreational activity. It is a place that has been studied before, but not in a more in-depth method incorporating quantitative and qualitative analyses. It is also a place that has gone through several stages of development and is the target of many opinions based on casual observations, at times due to these changes.

This thesis focuses on an ethnography of place in this particular plaza in an effort to more thoroughly analyze how people use the space and how it came together to become the plaza known by Portlanders today. This is done through the use of random video observations, direct observations, and in-depth interviews with those who were involved in the creation of the plaza. Analysis of the video recordings includes pedestrian counts, behavioral maps, and common routes taken through the plaza. Direct observations provide more insight into the day-to-day activities of the plaza and the phenomenological perspective of the design elements. Interviews allow for a more complete timeline of events in order to assess the plaza properly.

By combining these methods based on other plaza-based ethnographies, it is concluded that the plaza is a well-used and successful space and even suggest possible areas of improvement. Methods are also assessed for future use on other city parks and plazas, possibly in a comparative context. 


\section{Acknowledgements}

For this thesis and all anthropological experience leading up to it, I would like to start by thanking Dr. Michael E. Smith for his guidance and for the opportunity to work on such a wonderful research project. Had I never been handed a copy of Whyte's City: Rediscovering the Center or tasked with pouring over heaps of public space literature, I never would have found my place in an Urban Studies graduate program.

For the other members of the Late Lessons in Early History research project, Benjamin Stanley, Dr. Barbara Stark, Dr. Sharon Harlan, Dr. Chris Boone, and Dr. George Cowgill, thank you so much for allowing me to be a part of the team and contribute to the project's scholarly articles. I learned more working with this interdisciplinary group than I could ever have learned in classes alone.

To my committee at Portland State University, Dr. Ethan Seltzer, Dr. Carl Abbott, and Dr. Hunter Shobe, I am so lucky to have had this super-group of Urbanists to help me create a solid thesis proposal and product. Thank you for your guidance and for allowing me to conduct the research project of my dreams. A big thanks, too, to the interviewees of this project for making this more complete.

I would also like to thank my family and friends for the encouragement and conversations. And to my business colleagues, Allison Duncan and Jason King, may we have more research projects like this to complete together in the future.

Lastly, I would like to thank my partner Conrad Zimmerman for all of his constant love and support. I wouldn't be where I am today without him. 


\section{Table of Contents}

Abstract

Acknowledgements...............................................................................................

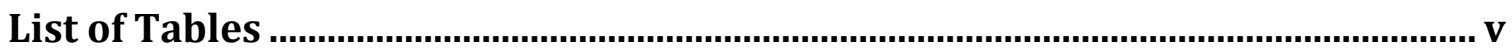

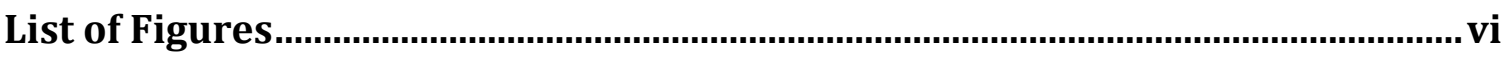

Chapter 1. Introduction ...................................................................................... 1

Chapter 2. Literature Review............................................................................... 5

Defining Public Space.................................................................................. 5

Public Space in a Historic Context................................................................................ 9

Contemporary Socio-Political Significance of Public Space ..........................................15

Public Space and Protest....................................................................................................................16

The Right to the City ......................................................................................................................19

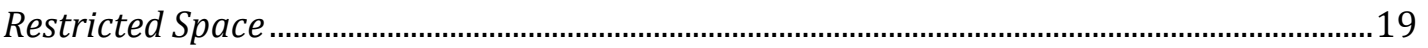

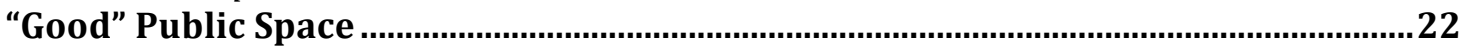

Similar Research Studies .....................................................................................28

Previous Research on the Urban Center Plaza ………………………………………...32

Chapter 3. Urban Center Plaza Research Project................................................... 35

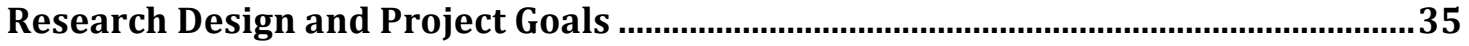

History and Overview of the Urban Center Plaza ……………………………………....36

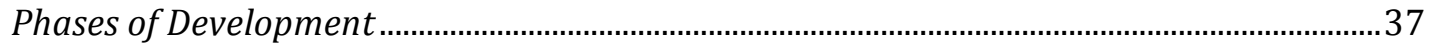

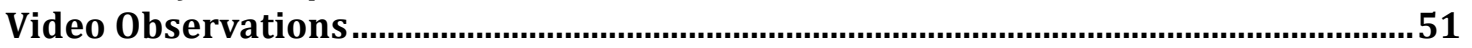

Participant Observations ..............................................................................................56

In-Depth Interviews..............................................................................................58

Alterations to Original Research Design ...................................................................58

Chapter 4. Analysis and Results......................................................................60

Behavior in the Urban Center Plaza ........................................................................61

Pedestrian Counts Per Week …………………………………………………………………...61

Seating Behavior ……………………………………………………………………………………...66

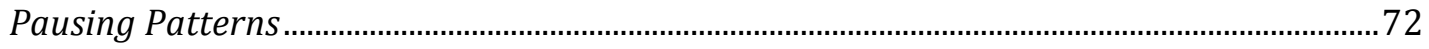

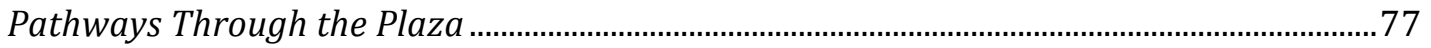

The Daily Life of the Urban Center Plaza ...................................................................................80

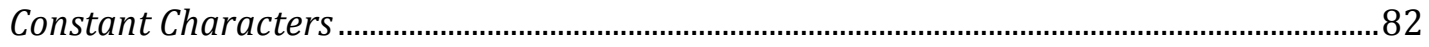

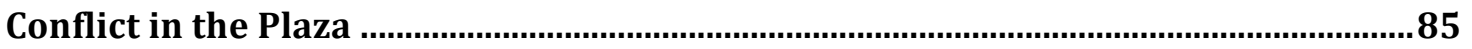

Design Concerns ................................................................................................................................

Publicness of the Plaza ……………………………………………………………………….....99

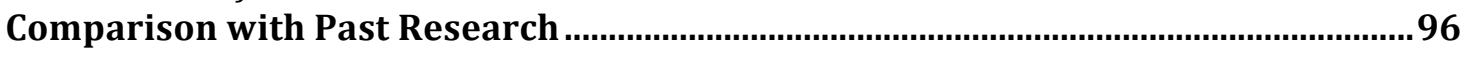

Chapter 5. Discussion and Conclusions............................................................ 98

General Conclusions on the Urban Center Plaza.........................................................98

Suggestions for Improvement ..................................................................................... 100

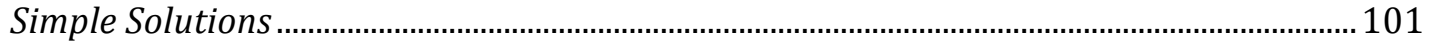

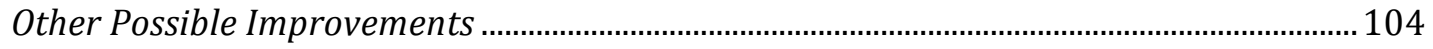

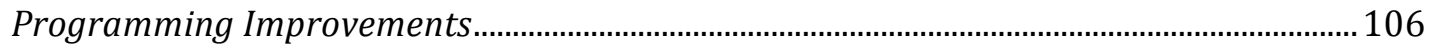

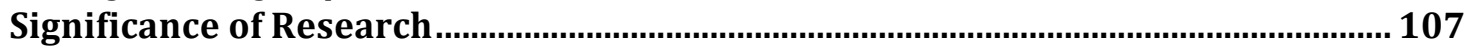


Suggestions for Future Research.

Project Limitations

Final Thoughts.

Works Cited ...........................................................................................................118

Appendix A: Randomized Video Observation Schedule ....................................123

Appendix B: Notification of Video Observation...................................................124

Appendix C: Video File Records and Times............................................................ 125

Appendix D: In-Depth Interviews Conducted ......................................................129

Appendix E: In-depth Interview Questions......................................................... 130

Appendix F: In-depth Interview Consent Form .................................................. 131

Appendix G: Total Behavioral Counts .................................................................... 133

Appendix H: Urban Center Plaza Project Report by the Portland Development

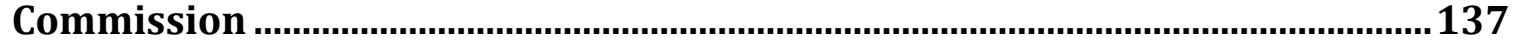




\section{List of Tables}

Table 1: Open Space Typology ……………………………………………………………..

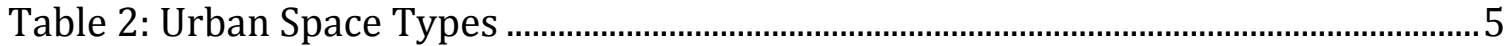

Table 3: Open space typology …………………………………………………………….... 8

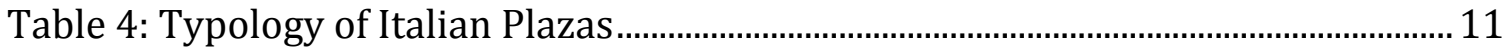

Table 5: Design \& Management Recommendations for Public Open Space..................22

Table 6: Overview of methods used per research question ..............................................36

Table 7: Types of steps found in the Urban Center Plaza ..................................................51

Table 8: Climate data for Portland, Oregon (Threadex Station) 1981-2010 ................ 57 


\section{List of Figures}

Figure 1: Location of Urban Center Plaza on the Portland State University campus in

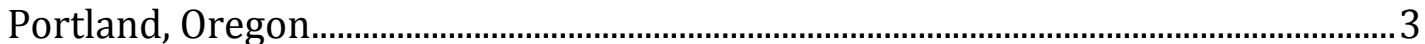

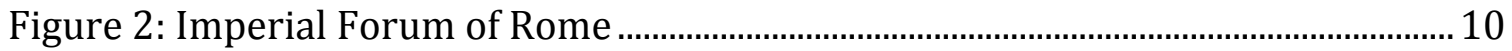

Figure 3: Teotihuacan, the first large city in Mesoamerica, showing the Avenue of the Dead and large plaza near the Pyramid of the Moon.................................................12

Figure 4: Piazza Nobili, Florence: A neighborhood courtyard used instead for parking.

Figure 5: Typical neighborhood in Fez showing interior courtyards and a distinct

lack of larger public space ..........................................................................................15

Figure 6: Tiananmen Square, Beijing, China .................................................................... 16

Figure 7: Zuccotti Park, New York City, as made famous by the Occupy Wall Street movement in 2011 .................................................................................................. 17

Figure 8: Occupy Portland Camp at Chapman Square Park .............................................. 18

Figure 9: Though technically illegal, "yarn bombing" in Portland helps create a sense

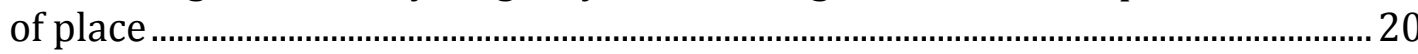

Figure 10: Prohibited Behavior in Zuccotti Park, New York City.......................................21

Figure 11: Strøget, Copenhagen, an extremely popular pedestrian street.....................22

Figure 12: Leon Krier's definition of good public space ...................................................23

Figure 13: Bryant Park, redesigned in 1981, is still extremely successful.....................24

Figure 14: Director Park, 2011, large-scale chess board section of the plaza with café to the left and wading pool in the background.......................................................26

Figure 15: Jan Gehl's human dimension, the contrast of the human capability for perspective and recognition ..................................................................................... 31

Figure 16: Original 6-block plan design of University District..........................................37

Figure 17: A game of chess in the intimate upper area of Pioneer Courthouse Square with the large open space and tiered steps in the background.................................38

Figure 18: Early sketch of plaza including light rail moving through ............................. 40

Figure 19: Phase one of the upper area of the Urban Center Plaza, before streetcar and Recreation Center building construction ......................................................... 41

Figure 20: A large event in Phase 2 of the Urban Center Plaza, after streetcar came through, and before the storm water retrofit, light rail, and Recreation Building

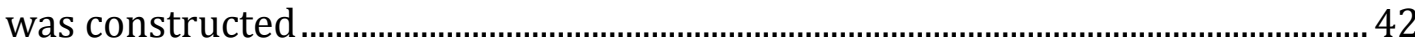

Figure 21: Plan for storm water retrofit by Nevue Ngan, before the light rail, but taking it into account.

Figure 22: Stormwater retrofit by Nevue Ngan where east steps used to be, part of Phase 3 44

Figure 23: Phase 4 of the upper area of the Urban Center Plaza...................................... 45

Figure 24: Map of the Urban Center Plaza ............................................................................ 47

Figure 25: View from the northwest of lower plaza and cafe seating near restaurants

Figure 26: Northeastern corner near entrance to Urban Center building (left) and Portland State bookstore 
Figure 27: View of plaza looking east from top level of street, ramp and more stairs to the right, arcaded southeast corner in the distance

Figure 28: Illustration showing the grade changes of the plaza levels, looking from the east. 50

Figure 29: Image of plaza showing three types of stairs .................................................51

Figure 30: The Perspective of the Camera's Position Looking Northwest..................... 53

Figure 31: Entrance Points into the Urban Center Plaza ..................................................... 56

Figure 32: Total Pedestrian Counts for Week One .............................................................62

Figure 33: Average Pedestrian Counts Per Hour for Week One .........................................63

Figure 34: Total Pedestrian Counts Per Hour for Week Two ............................................. 64

Figure 35: Average Pedestrian Counts Per Hour for Week Two ......................................... 64

Figure 36: Average Pedestrian Counts for Weeks One and Two......................................65

Figure 37: Total Sit Events During Week One ....................................................................67

Figure 38: Total Sit Events During Week Two ...................................................................68

Figure 39: The less popular upper tiered seats to the west .............................................. 70

Figure 40: Average Sit Events Per Hour for Weeks One and Two ................................... 71

Figure 41: Percentage of Sit Events as per Total Pedestrian Counts............................... 72

Figure 42: Total Sit and Pause Event Map for September 21, 2011 .............................. 73

Figure 43: Average Pause Events Per Hour for Weeks One and Two .............................. 74

Figure 44: Total Sit and Pause Event Map for September 30, 2011 ............................... 76

Figure 45: Frequent Travel Pathways through the plaza, with common pinch points shown in red and major westward routes numbered................................................79

Figure 46: Ramp and west side steps looking east.............................................................. 86

Figure 47: Cobblestone section of northwestern corner ...................................................8

Figure 48: View from the entrance of the Urban Center building looking south, granite sculpture on the left .....................................................................................89

Figure 49: Phase 5 bicycle rack addition and street furniture rearrangement ........... 90

Figure 50: "No Skating" sign in pavement on west side of plaza entrance..................... 93

Figure 51: Possible suggested table and chair layout for upper plaza ......................... 102

Figure 52: PSU Farmer's Market at the Park Blocks west of the Urban Center Plaza 


\section{Chapter 1. Introduction}

Since the earliest cities, open space has been a critical component of the urban environment (Briggs, 2004; Smith, 2002). Defined as any urban ground space, regardless of public accessibility, that is not roofed by an architectural structure, open space can be divided into several different categories across space and time encompassing everything from traditional public parks to neighborhood gardens and highway medians (Stanley, Stark, Johnston, \& Smith; accepted for publication).

In analyzing public space, it is important to consider the context of this type of space in regards to form and function through time. While other typologies of open space and public space in cities have been created focusing on morphology (e.g., Carmona, 2010b; Zucker, 1959), this thesis will be using the open space typology which was previously created (see Table 1) to frame this particular space. The purpose of this typology is to allow for a standardized comparison of urban open space regardless of the culture, field of study, or time period (see Stanley et al., accepted for publication, for a full explination of the typology). It is organized by form, function, scale, and land cover of open spaces in an effort to more thoroughly describe space in a diverse set of situations. 


\begin{tabular}{|c|c|c|c|c|c|c|c|}
\hline Scale & $\begin{array}{l}\text { Transport } \\
\text { facilities }\end{array}$ & Streets & Plazas & $\begin{array}{l}\text { Recreational } \\
\text { space }\end{array}$ & $\begin{array}{l}\text { Incidental } \\
\text { space }\end{array}$ & $\begin{array}{l}\text { Parks and } \\
\text { gardens }\end{array}$ & $\begin{array}{l}\text { Food } \\
\text { production } \\
\text { areas } \\
\end{array}$ \\
\hline City & $\begin{array}{l}\text { Airports; } \\
\text { harbors; } \\
\text { freeways }\end{array}$ & $\begin{array}{l}\text { Central } \\
\text { boulevards }\end{array}$ & $\begin{array}{l}\text { Large formal } \\
\text { plazas }\end{array}$ & $\begin{array}{l}\text { Stadiums; } \\
\text { greenbelts }\end{array}$ & $\begin{array}{l}\text { Semi-wild } \\
\text { areas }\end{array}$ & $\begin{array}{l}\text { Large formal } \\
\text { parks and } \\
\text { gardens }\end{array}$ & $\begin{array}{l}\text { Orchards; } \\
\text { Large } \\
\text { agricultural } \\
\text { plots }\end{array}$ \\
\hline Neighborhood & $\begin{array}{l}\text { Train stations; } \\
\text { city gate } \\
\text { areas; storage } \\
\text { lots }\end{array}$ & Streets & $\begin{array}{l}\text { neighbor-hood } \\
\text { plazas }\end{array}$ & $\begin{array}{l}\text { Sports } \\
\text { facilities; } \\
\text { playgrounds }\end{array}$ & $\begin{array}{l}\text { Empty lots; } \\
\text { transportation } \\
\text { borders }\end{array}$ & $\begin{array}{l}\text { Institutional } \\
\text { gardens; small } \\
\text { parks; } \\
\text { cemeteries }\end{array}$ & $\begin{array}{l}\text { Neighborhood } \\
\text { gardens; } \\
\text { communal } \\
\text { grazing land }\end{array}$ \\
\hline Residence & Parking areas & Alleys; paths & $\begin{array}{l}\text { Interior } \\
\text { courtyards }\end{array}$ & $\begin{array}{l}\text { Houseyard } \\
\text { Playspace }\end{array}$ & $\begin{array}{l}\text { Marginalized } \\
\text { space }\end{array}$ & $\begin{array}{l}\text { Houseyard } \\
\text { gardens }\end{array}$ & $\begin{array}{l}\text { Kitchen } \\
\text { gardens }\end{array}$ \\
\hline
\end{tabular}

Table 1: Open Space Typology (Stanley, Stark, Johnston, \& Smith, accepted for publication)

In contemporary urban environments, plazas, parks, sidewalks, and other public or semi-public places provide the necessary spaces in which individuals can maneuver through the landscape, socialize, and otherwise participate in the urban civic sphere (Al-hagla, 2008; Carmona, 2010b; Jacobs, 1961; Mitchell, 2003). Portland, Oregon, known for its numerous urban parks and convenient public plazas, is an ideal place to study the interaction of people in space in conjunction with the physical design elements (Orloff, 2004; Ozawa, 2004).

In this case, the Urban Center Plaza, a privately owned public space on Portland State University's campus, provides an excellent opportunity for an analysis of planning, design, behavior, and change in form of a major urban open space (see Figure 1). This plaza was a major project for the city and university and has undergone several changes over time as the area around it was redeveloped (Portland Development Commission, 1999). Currently, students and commuters alike use the plaza for many reasons and it frequently provides a physical connection to the rest of the university. Student groups have also conducted prior 
research during its various stages of construction providing a unique look into the evolution of space and use over time.

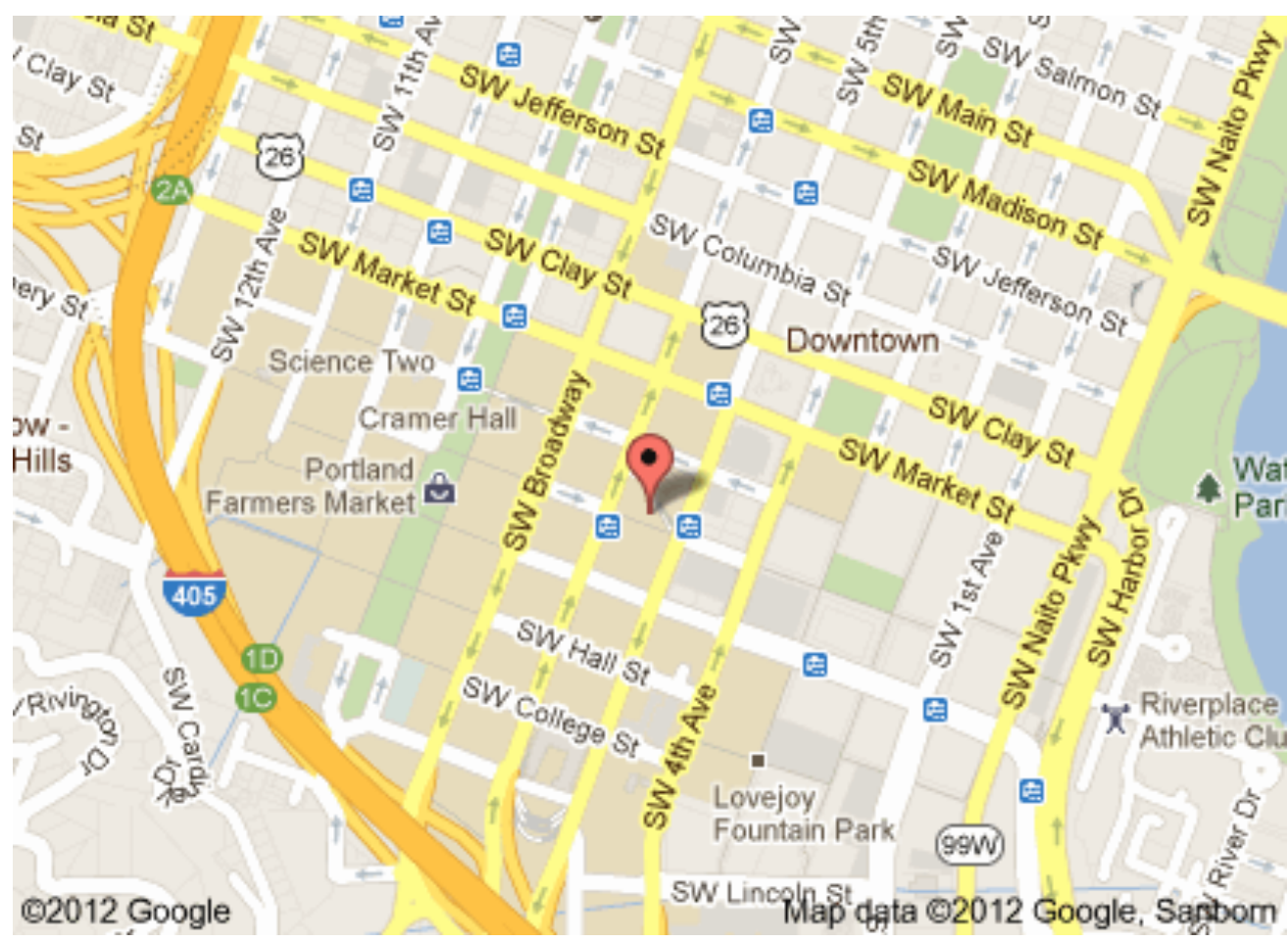

Figure 1: Location of Urban Center Plaza on the Portland State University campus in Portland, Oregon

Understanding the ways in which we interact with space, or how the process of production of space affects design and therefore the use of it, can allow for a better process as well as product for future development. Rather than redesigning space after it is out of style, or worse, creating spaces that have no desirability, we can prevent costly measures in the future by simply avoiding bad design (for examples see Smithsimon, 2008; Whyte, 1990). By focusing on the human scale, as much of Portland has strived for in its urban design, we can transcend trends and time and create lasting public spaces in an effort to improve quality of life in our urban environments (Gehl, 2010). 
The goal, ultimately, is to add to the literature regarding how people use public space with a more thorough understanding of not only the current built environment, but how it came to be this way and why. In doing so, this research may assist in the future creation or alteration of better public space for people through the testing of this method of spatial ethnographic research on this particular plaza in Portland, Oregon. Future research could include a comparison of these methods or the application of these methods to compare other spaces in a contemporary context elsewhere. Overall, the research goals were to explore:

1. The history of the Urban Center Plaza.

2. How people use the Urban Center Plaza.

3. What, if anything, has changed in seven years based on previous research at the Urban Center Plaza focusing on behavior and attitudes associated with the Plaza.

4. How these research methods in particular can shed light on human behavior in public space for future analysis and improvement of urban design for open space.

To achieve these goals a spatial ethnography of the plaza was conducted drawing from Anthropology and similar ethnographic research studies on plazas by Low (2000). A quantitative video observation of the space was also conducted in order to produce pedestrian counts and behavior maps in conjunction with direct observations like those made famous by Whyte (1990). Interviews were conducted with the major players in the creation of the plaza and previous research was consulted in order to analyze the plaza in its historical context. Results and methods were then compared with those of Whyte (1990) and Gehl (2010), and applied to the current state of the Urban Center Plaza with final conclusions and suggestions offered for the space. 


\section{Chapter 2. Literature Review}

\section{Defining Public Space}

Public space has been defined in various ways in the modern context. Carr et al.'s definition emphasizes the accessibility of the space, defining public space as “open, publicly accessible places" (Carr, Francis, Rivlin, \& Stone, 1992), despite the fact that some public space is within buildings or restricted to certain times of the day or members of the public. Low \& Smith (2006) instead focus on the privatization of public space arguing "it is impossible to conceive of public space today outside the social generalization of private space and its full development as a product of modern capitalist society". Carmona et al. (2008) (prior to Carmona's elaborate typology of open space) state "public space (narrowly defined) relates to all those parts of the built and natural environment where the public has free access (see Table 2 for typology). It encompasses: all the streets, squares, and other rights of way... the open spaces and parks; and the 'public/private' spaces where public access is unrestricted."

Table 2: Urban Space Types (Carmona, 2010a)

\begin{tabular}{|c|c|c|}
\hline Space Type & Distinguishing Characteristics & Examples \\
\hline & 'Positive' spaces & \\
\hline $\begin{array}{l}\text { 1. Natural/semi-natural } \\
\text { Space }\end{array}$ & $\begin{array}{l}\text { Natural and Semi-natural features } \\
\text { within urban areas, typically under } \\
\text { state ownership }\end{array}$ & $\begin{array}{l}\text { Rivers, natural features, } \\
\text { seafronts, canals }\end{array}$ \\
\hline 2. Civic space & $\begin{array}{l}\text { The traditional forms of urban } \\
\text { space, open and available to all } \\
\text { even if temporarily controlled }\end{array}$ & Streets, squares, promenades \\
\hline 3. Public open space & $\begin{array}{l}\text { Managed open space, typically } \\
\text { green and available and open to all, } \\
\text { even if temporarily controlled } \\
\text { 'Negative' spaces }\end{array}$ & $\begin{array}{l}\text { Parks, gardens, commons, urban } \\
\text { forests, cemeteries }\end{array}$ \\
\hline 4. Movement space & $\begin{array}{l}\text { Space dominated by movement } \\
\text { needs, largely for motorized } \\
\text { transportation }\end{array}$ & $\begin{array}{l}\text { Main roads, motorways, } \\
\text { railways, underpasses }\end{array}$ \\
\hline
\end{tabular}




\begin{tabular}{|c|c|c|}
\hline 5. Service space & $\begin{array}{l}\text { Space dominated by modern } \\
\text { servicing requirement needs }\end{array}$ & Car parks, service yards \\
\hline 6. Left over space & $\begin{array}{l}\text { Space left over after development, } \\
\text { often designed without function }\end{array}$ & $\begin{array}{l}\text { 'SLOAP' (space left over after } \\
\text { planning), Modernist open space }\end{array}$ \\
\hline 7. Undefined space & $\begin{array}{l}\text { Undeveloped space, either } \\
\text { abandoned or awaiting } \\
\text { development } \\
\text { Ambiguous spaces }\end{array}$ & $\begin{array}{l}\text { Redevelopment space, } \\
\text { abandoned space, transient } \\
\text { space }\end{array}$ \\
\hline 8. Interchange space & $\begin{array}{l}\text { Transport stops and interchanges, } \\
\text { whether internal or external }\end{array}$ & $\begin{array}{l}\text { Metros, bus interchanges, } \\
\text { railway stations, but/tram stops }\end{array}$ \\
\hline 9. Public 'private' space & $\begin{array}{l}\text { Seemingly public external space, in } \\
\text { fact privately owned and to greater } \\
\text { or lesser degrees controlled }\end{array}$ & $\begin{array}{l}\text { Privately owned 'civic' space, } \\
\text { business parks, church grounds }\end{array}$ \\
\hline 10. Conspicuous spaces & $\begin{array}{l}\text { Public spaces designed to make } \\
\text { strangers feel conspicuous and, } \\
\text { potentially unwelcome }\end{array}$ & $\begin{array}{l}\text { Cul-du-sacs, dummy gated } \\
\text { enclaves }\end{array}$ \\
\hline $\begin{array}{l}\text { 11. Internalized 'public' } \\
\text { space }\end{array}$ & $\begin{array}{l}\text { Formally public and external uses, } \\
\text { internalized and, often, privatized }\end{array}$ & $\begin{array}{l}\text { Shopping/leisure malls, } \\
\text { introspective mega-structures }\end{array}$ \\
\hline 12. Retail space & $\begin{array}{l}\text { Privately owned but publicly } \\
\text { accessible exchange spaces }\end{array}$ & $\begin{array}{l}\text { Shops, covered markets, petrol } \\
\text { stations }\end{array}$ \\
\hline 13. Third place spaces & $\begin{array}{l}\text { Semi-public meeting and social } \\
\text { places, public and private }\end{array}$ & $\begin{array}{l}\text { Cafes, restaurants, libraries, } \\
\text { town halls, religious buildings }\end{array}$ \\
\hline $\begin{array}{l}\text { 14. Private 'public' } \\
\text { space }\end{array}$ & $\begin{array}{l}\text { Publicly owned, but functionally } \\
\text { and user determined space }\end{array}$ & $\begin{array}{l}\text { Institutional grounds, housing } \\
\text { estates, university campuses }\end{array}$ \\
\hline $\begin{array}{l}\text { 15. Visible private } \\
\text { space }\end{array}$ & $\begin{array}{l}\text { Physically private, but visually } \\
\text { private space }\end{array}$ & $\begin{array}{l}\text { Front gardens, allotments, gated } \\
\text { squares }\end{array}$ \\
\hline 16. Interface spaces & $\begin{array}{l}\text { Physically demarked but publicly } \\
\text { accessible interfaces between } \\
\text { public and private space }\end{array}$ & $\begin{array}{l}\text { Street cafes, private pavement } \\
\text { space }\end{array}$ \\
\hline $\begin{array}{l}\text { 17. User selecting } \\
\text { spaces }\end{array}$ & $\begin{array}{l}\text { Spaces for selected groups, } \\
\text { determined (and sometimes } \\
\text { controlled) by age or activity } \\
\text { Private space }\end{array}$ & $\begin{array}{l}\text { Skateparks, playgrounds, sports } \\
\text { fields/grounds/courses }\end{array}$ \\
\hline 18. Private open space & Physically private open space & $\begin{array}{l}\text { Urban agricultural remnants, } \\
\text { private woodlands }\end{array}$ \\
\hline $\begin{array}{l}\text { 19. External private } \\
\text { space }\end{array}$ & $\begin{array}{l}\text { Physically private spaces, grounds } \\
\text { and gardens }\end{array}$ & $\begin{array}{l}\text { Gated streets/enclaves, private } \\
\text { gardens, private sports clubs, } \\
\text { parking courts }\end{array}$ \\
\hline $\begin{array}{l}\text { 20. Internal private } \\
\text { space }\end{array}$ & Private or business space & Offices, houses, etc. \\
\hline
\end{tabular}

In further subdividing the types of space, Al-Hagla's classification of open

space into "green space" and "grey space" based literally on its respective ground-

cover has been adapted to the category of open space, and public space within it

(see Table 3) (Al-hagla, 2008). Here, green space represents "a subset of open space, consisting of any vegetated land or structure, water, or geological feature within 
urban areas" and grey space refers to more civic-oriented spaces such as "urban squares, market places and other hard landscaped areas" (p. 164). Parks would be one typical example of green space, while their counterpart the plaza would be typically grey space. Though each of these could also be a combination of the two as is the case in places like Central Park in New York City, it is possible to either generalize the space into the dominant form or to subdivide it if it is large enough to more accurately describe the space. In this instance, Central Park would be considered green space overall, but also contains many of the other open space categories, such as recreational space, outlined in the typology (see Table 1). 
Table 3: Open space typology (Al-hagla, 2008)

\begin{tabular}{|c|c|c|}
\hline Space Type & Description & Primary Function \\
\hline & Greenspaces & \\
\hline Parks and gardens & $\begin{array}{l}\text { Areas of land, normally enclosed, designed, } \\
\text { constructed, managed and maintained as a } \\
\text { public park or garden. }\end{array}$ & $\begin{array}{l}\text { Informal activity or relaxation, } \\
\text { social and community purposes, } \\
\text { and horticultural or } \\
\text { arboricultural displays. }\end{array}$ \\
\hline $\begin{array}{l}\text { Amenity } \\
\text { greenspace }\end{array}$ & $\begin{array}{l}\text { Managed and maintained landscaped areas } \\
\text { with no designated specific use by people. }\end{array}$ & $\begin{array}{l}\text { Providing visual amenity or } \\
\text { separating different buildings or } \\
\text { land uses for environmental, } \\
\text { visual or safety reasons. They } \\
\text { may also be used, incidentally, } \\
\text { as wildlife habitats. }\end{array}$ \\
\hline $\begin{array}{l}\text { Children's play } \\
\text { areas }\end{array}$ & $\begin{array}{l}\text { Designated and maintained areas } \\
\text { providing safe and accessible } \\
\text { opportunities for children's play normally } \\
\text { connected to amenity greenspace. }\end{array}$ & $\begin{array}{l}\text { Provide safe facilities for } \\
\text { children to play, usually close to } \\
\text { home and under informal } \\
\text { supervision from nearby } \\
\text { houses. }\end{array}$ \\
\hline Sports facilities & $\begin{array}{l}\text { Designed, constructed, managed and } \\
\text { maintained large and generally (although } \\
\text { not always) flat areas of grassland or } \\
\text { specially-designed artificial surfaces, used } \\
\text { primarily for designated sports. }\end{array}$ & $\begin{array}{l}\text { Accommodate practice, training } \\
\text { and competition for recognized } \\
\text { outdoor sports. }\end{array}$ \\
\hline Green corridors & $\begin{array}{l}\text { Routes linking different areas within a } \\
\text { town or city as part of a designated and } \\
\text { managed network and used for walking, } \\
\text { cycling or horse riding or linking towns } \\
\text { and cities to their surrounding countryside } \\
\text { or country parks. }\end{array}$ & $\begin{array}{l}\text { Allow safe, environment- } \\
\text { friendly movement within } \\
\text { urban areas. Moreover, they } \\
\text { support wildlife colonization } \\
\text { and therefore habitat creation. }\end{array}$ \\
\hline $\begin{array}{l}\text { Natural/semi- } \\
\text { natural } \\
\text { greenspaces }\end{array}$ & $\begin{array}{l}\text { Undeveloped land with little or only } \\
\text { limited maintenance which have been } \\
\text { planted with wild flowers or colonized by } \\
\text { vegetation and wildlife. They also include } \\
\text { woodland, railway embankments, river } \\
\text { and canal banks and derelict land, which } \\
\text { may in some cases be thought of as } \\
\text { temporary natural greenspace. }\end{array}$ & $\begin{array}{l}\text { To promote biodiversity and } \\
\text { nature conservation. }\end{array}$ \\
\hline \multirow[t]{2}{*}{$\begin{array}{l}\text { Other functional } \\
\text { greenspaces }\end{array}$} & $\begin{array}{l}\text { Essentially allotments, the yards of } \\
\text { religious buildings and cemeteries. }\end{array}$ & \\
\hline & Greyspaces & \\
\hline $\begin{array}{l}\text { Civic squares and } \\
\text { plazas }\end{array}$ & $\begin{array}{l}\text { Often containing statues or fountains and } \\
\text { primarily paved, sometimes providing a } \\
\text { setting for important public buildings. }\end{array}$ & \\
\hline Market places & Usually with historic connotations. & \\
\hline Pedestrian streets & $\begin{array}{l}\text { Usually former roads which have been } \\
\text { paved over and provided with seats and } \\
\text { planters. }\end{array}$ & \\
\hline $\begin{array}{l}\text { Promenades and } \\
\text { sea fronts }\end{array}$ & $\begin{array}{l}\text { Usually used for recreational activities. } \\
\text { They have special value when located at } \\
\text { historical areas. }\end{array}$ & \\
\hline
\end{tabular}


Plazas in particular can be defined as intentionally built multi-purpose open space framed by buildings on most sides, usually grey space, and often open to public access (Stanley et al., accepted for publication). In accordance to this typology, plazas, like other open space, range in scale from City, Neighborhood, and Residence, or citywide, intermediate, and individual buildings. This emphasizes how they are used within the city as well as their scale rather than their precise size. City scale would refer to plazas often planned by government or religious authorities aimed at serving large portions of the population. The intermediate scale impacts multiple residences more locally at the neighborhood, district, or block level, and may be more numerous and smaller in scale. Individual buildings or residences may contain a plaza such as an interior courtyard of paved or packed dirt that may or may not be accessible to the public. With this typology in mind, public spaces, and plazas in particular, are reviewed historically through time.

\section{Public Space in a Historic Context}

Historically, open spaces in ancient cities were fairly uncommon given that the earliest cities were dense and comparatively small, typically walled and primarily concerned with housing their populations. Streets were primarily used for transportation of people and goods and doubled as the public spaces of the cities where work like butchering may be conducted and small markets occurred. Public spaces in the sense of the modern definition of 'public' were not created until much later and varied greatly depending on the culture. Often, these later plazas were 
designed and planned by the ruling elite of the time in order to establish gathering areas for commerce, military, or religious functions (M. E. Smith, 2002).

The most frequent starting point for discussion on open space and plazas in particular is the ancient Greek agora. This space, and the Roman-planned forums, have become the foundational symbol of the public sphere in common parlance as well as public space literature (Owens, 1991; Ward-Perkins, 1974; Wycherley, 1976). While not technically public in the sense that it was accessible to all, the Roman Forum is still an impressive and important plaza of note.

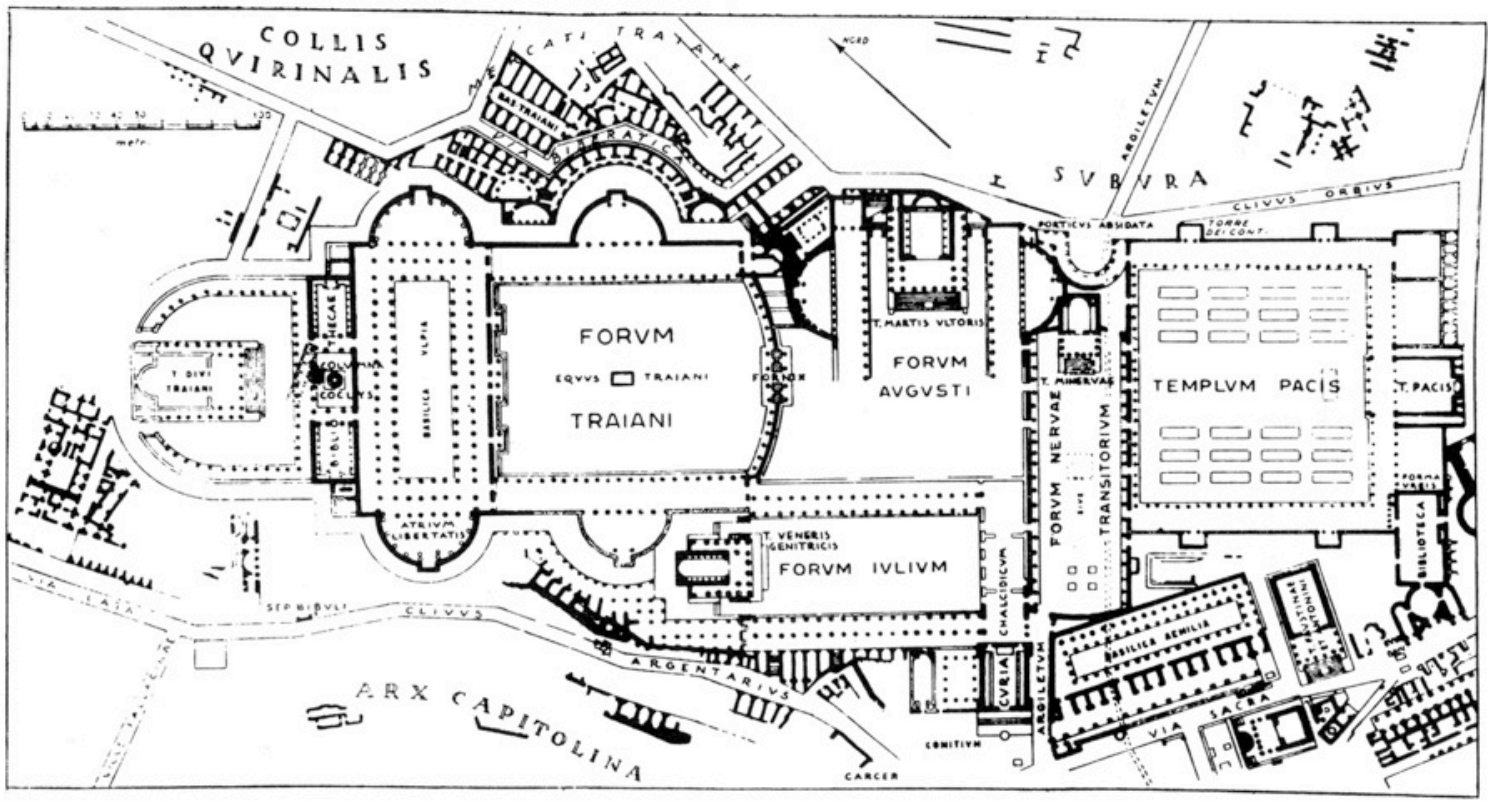

Figure 2: Imperial Forum of Rome (Ward-Perkins, 1974; p. 108)

Medieval European plazas served various purposes in the town's social and economic spheres (Carmona et al., 2008; Carr et al., 1992; Zucker, 1959). The change in ideals during the Renaissance and the emphasis on aesthetics in plaza design, as famously classified by Sitte (1889), eventually altered the form of cities (especially in Italy but Europe in general). Fusch has also created a modern typology 
of plazas in Italy looking at both traditional plaza form and modern usage (see Table

4) (Fusch, 1994).

Table 4: Typology of Italian Plazas (Fusch, 1994)

\begin{tabular}{|c|c|c|}
\hline Type & Characteristics & Examples \\
\hline Relic & $\begin{array}{l}\text { Located in historic urban cores; pre- } \\
1400 \text { in origin; little used for public } \\
\text { gatherings }\end{array}$ & $\begin{array}{l}\text { La Cisterna (San Gimingano); di } \\
\text { Danti (Florence); dei Cimatori } \\
\text { (Florence) }\end{array}$ \\
\hline Monumental & $\begin{array}{l}\text { Located in historic urban cores; pre- } \\
1500 \text { in origin; front monumental } \\
\text { churches, public buildings, and palaces }\end{array}$ & $\begin{array}{l}\text { San Pietro (Rome); Santa Croce } \\
\text { Nobili, Tanucci, Giorgini (Florence) } \\
\text { (Florence); del Campo (Siena); del } \\
\text { Duomo (Milan); del Popolo } \\
\text { (Orvieto); Maggiore (Bologna) }\end{array}$ \\
\hline $\begin{array}{l}\text { Neighborhood } \\
\text { market }\end{array}$ & $\begin{array}{l}\text { Found throughout Italian cities; } \\
\text { markets for fresh fruit and vegetables; } \\
\text { enterprises include bars, restaurants, } \\
\text { and gasoline stations }\end{array}$ & Nobili, Tanucci, Giorgini (Florence) \\
\hline Mercantile & $\begin{array}{l}\text { Regional shopping center; numerous } \\
\text { shops; crowded with people and } \\
\text { vehicles }\end{array}$ & Dalmazia and della Cure (Florence) \\
\hline $\begin{array}{l}\text { Neighborhood } \\
\text { park }\end{array}$ & $\begin{array}{l}\text { Small, orthogonal, landscaped; post- } \\
\text { 1600; contain seating, fountains, } \\
\text { statuary, and play areas for children }\end{array}$ & D'Azeglio (Florence) \\
\hline Vehicular & $\begin{array}{l}\text { Sometimes former monumental or } \\
\text { market piazzas; sometimes widened } \\
\text { portions of main intersections }\end{array}$ & Del Terzolle, Liberta (Florence) \\
\hline
\end{tabular}

With the exception of Madanipour (2003) and his inclusion of ancient Chinese and Islamic cities, most of the academic discussion of plazas and public space seem to center around Western examples. An attempt is made to broaden this scope in an effort to expand the parameters by which we discuss public life and public space. While a Western public plaza is analyzed here, it is important to consider alternative cultural concepts and historical usages in order to gain a better understanding of how public space is used in general and what sort of design considerations can be incorporated into this conversation of good public space. The following is an example of public spaces utilizing the typology mentioned previously (see Table 1) which presents these spaces in a broader context. 
Beginning with city level plazas, we see a distinct trend in the large-scale construction of these spaces by city governments or religious authorities once these hierarchical systems emerged. These plazas are distinctive in that they tend to be larger than other plazas in the city, are centrally located, and associated with major civic or religious institutions. Often they play a significant political or symbolic role but are also multi-purpose in nature serving as locations for cultural events, military assembly, commerce, and general social interaction. An early example of this is the Latin American planning tradition influenced by indigenous and colonial forces alike, as later outlined more formally in the Law of the Indies. This "central square of space, ringed by the cathedral, administration buildings, arsenal and customs house, and later the residences of the social elite, represented the double hierarchy of church and state" (Low, 1993, p. 76).

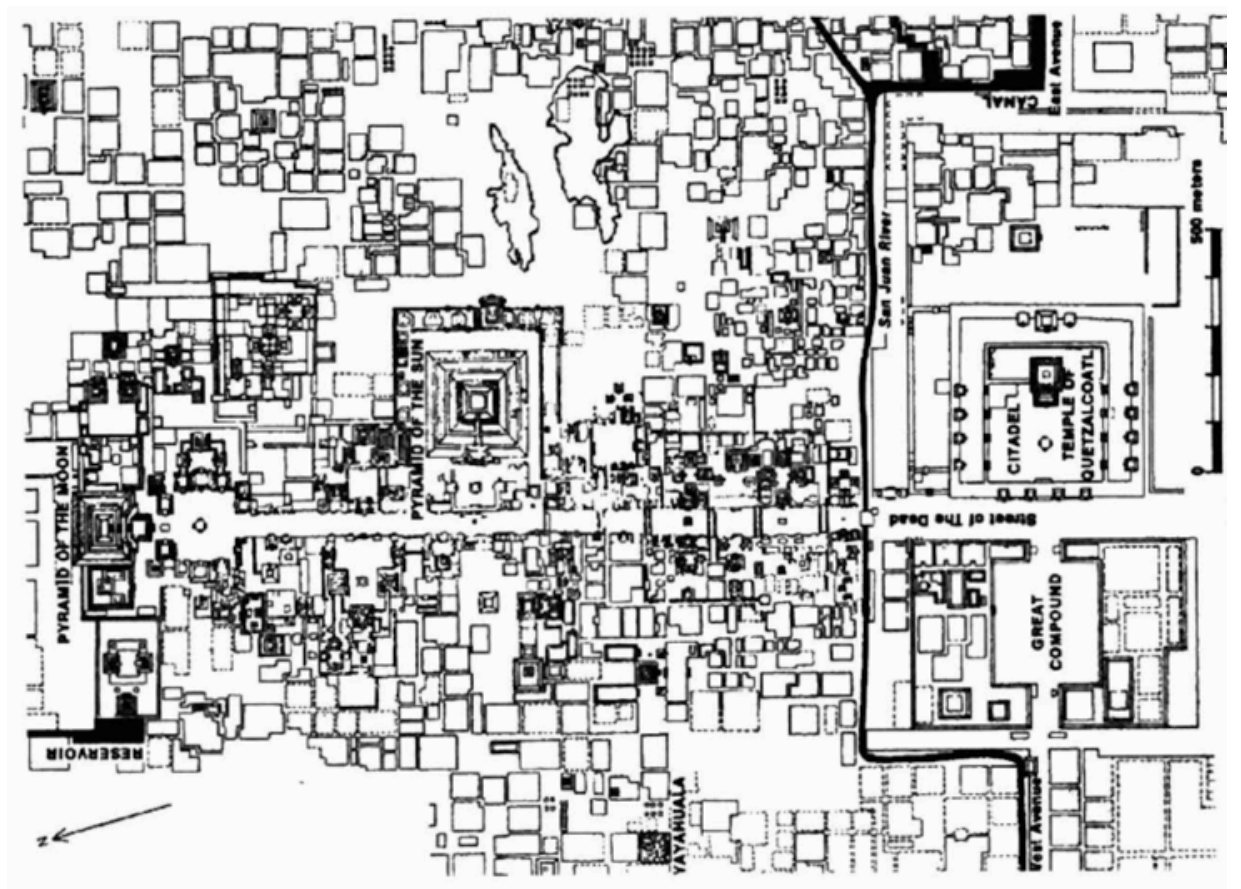

Figure 3: Teotihuacan, the first large city in Mesoamerica, showing the Avenue of the Dead and large plaza near the Pyramid of the Moon (M. E. Smith, 2002) 
Another example includes citywide plazas in Chinese ancient cities traditionally used as demonstrations of political control and order (Abramson, 2007). Contemporary Chinese cities are continuing this trend in their history due to the influence of globalization and are undergoing rapid redevelopment by state authorities, creating monumental plazas again representing state power, this time on a global scale (Ma \& Wu, 2005).

Intermediate level plazas are often more numerous, smaller in scale, and are used by individuals on the block and neighborhood level more frequently than the entire citywide population. The size of these varies widely, however, depending on the culture and city. A contemporary neighborhood plaza in a Chinese city may be the equivalent of a citywide plaza in a medium sized city like Portland. The most common reference of this type of plaza is the local medieval plaza scattered throughout the city, often making up the majority of open space in cities like $15^{\text {th }}$ century Florence (Weissman, 1982). These plazas were usually formed by removing buildings in front of churches to make room for the necessary activities such a space could provide (Harding, 2004). A non-Western example are the neighborhood plazas of Bhaktapur, Nepal, where residents frequent the local communal well and utilize the space for production and market functions (Levy, 1990). Today, some of these plazas in places like Italy are being used as parking lots with the rise in dominance of the automobile in contemporary cities with a medieval sense of space (Fusch, 1994). 


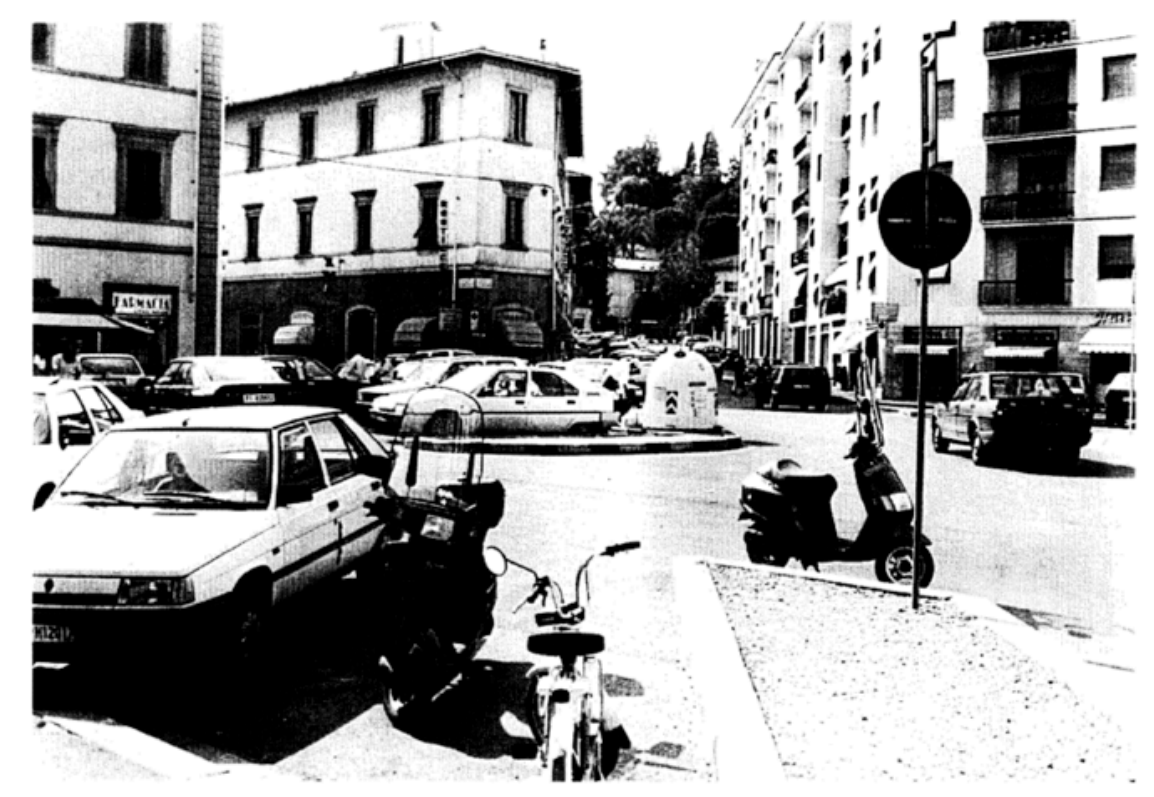

Figure 4: Piazza Nobili, Florence: A neighborhood courtyard used instead for parking (Fusch, $1994 ;$ p. 433)

Courtyards make up the smallest plazas, usually constructed of packed dirt or paved surfaces, partially or wholly enclosed by buildings, and can be private or semi-private spaces. And excellent example of this is the so-called 'Mediterraneanstyle" house, found from ancient Mesopotamia to the Incas of Peru where the patio is completely enclosed by the residence. In Roman Pompeii, nearly every house had an interior courtyard where one could cultivate kitchen gardens, keep pets, and eat outdoors in the traditional way at concrete u-shaped dining structures (Jashemski, 2008). Due to a lack of private space, courtyards are very important in some cities for the urban poor to provide space for daily activities and interaction. In Fez and many Islamic cities, the interior courtyard is also the dominant public space, found within the nestled and more secluded family compounds (see Figure 5) (Bianca, 2000). 


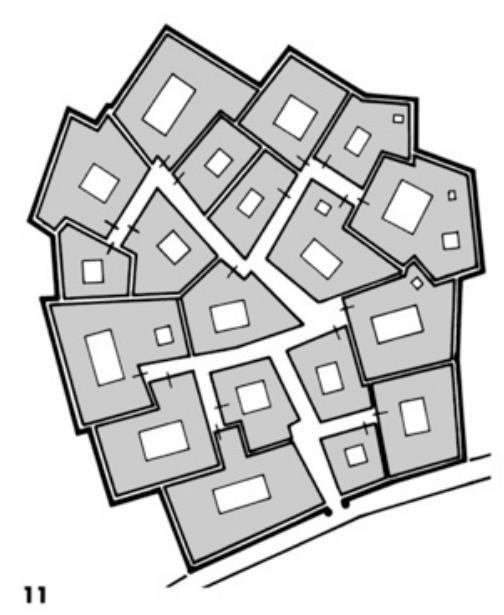

Figure 5: Typical neighborhood in Fez showing interior courtyards and a distinct lack of larger public space (Bianca, 2000; p. 39)

\section{Contemporary Socio-Political Significance of Public Space}

Plazas as public space are present in nearly every urbanized civilization, though they differ greatly in regards to creation, location, usage, and significance. Often they provide the multi-purpose space necessary to supplement private space or to interact in the civic life of the city. While sometimes restricted space, plazas can still be used for a wide range of activities, or used in different ways in spite of the restrictions placed upon it. Public access to things like plazas is unavoidably political, though, and the relation to the rights of the public in such places and the human rights issues surrounding it are in a constant state of conflict worldwide (Mitchell, 2003). Urban open spaces, because of their importance for the mass of inhabitants, provide an opportunity to investigate urban life and urban design, as well as the broader political fabric of society (Stanley et al., accepted for publication). 
Historically, open space has been altered and controlled, including plazas, for better surveillance or military transport and assembly by the institutions at large. China and Russia have been locations of contemporary political and social unrest where institutional control meets grassroots revolt. China's citywide scale plaza Tiananmen Square became instantly recognizable as a democratic symbol in 1989 after the violent government repression of protests (Lees, 1994). Large formal plazas were created in Soviet cities, like the Red Square in Moscow, as symbols of the socialist state where political gatherings and propaganda events would take place (Castillo, 1994).

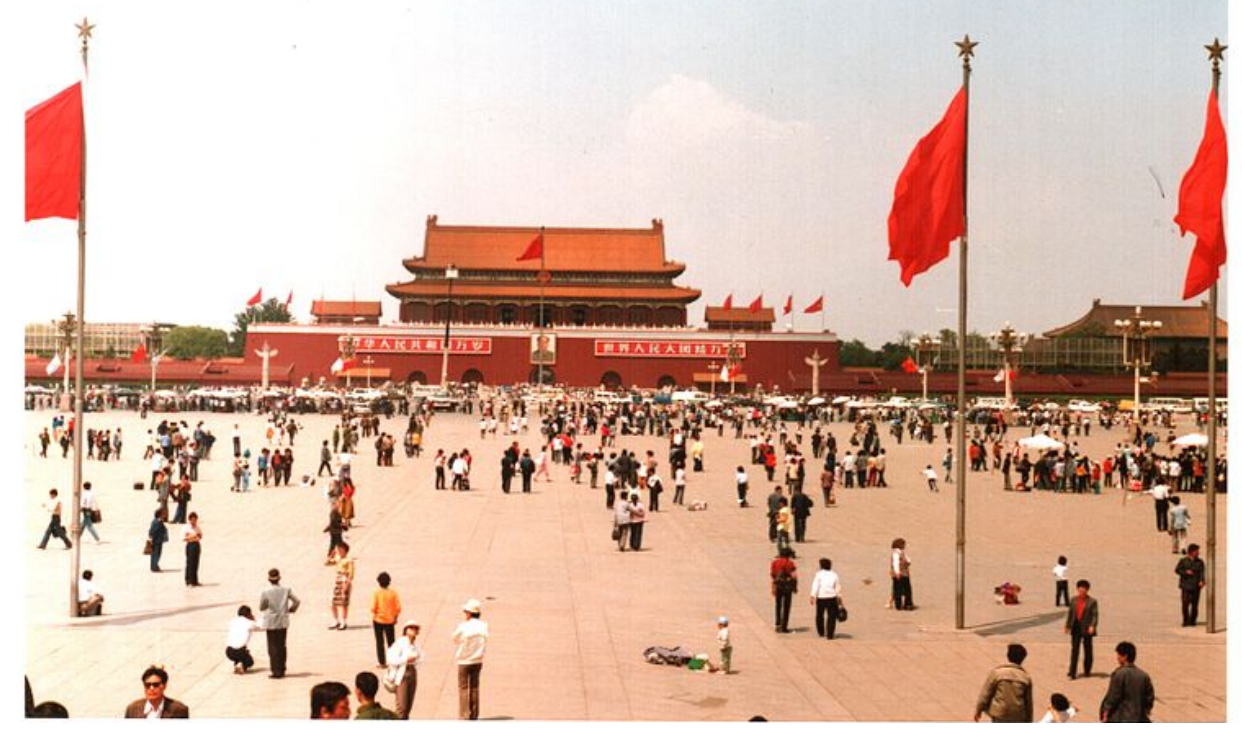

Figure 6: Tiananmen Square, Beijing, China (creative commons)

\section{Public Space and Protest}

More recently we've seen the continued importance of public space as a necessary part of protesting, despite the emphasis on technology as the new tool for coordination and communication. In Cairo, Tahrir Square is now a part of the global 
sphere as mass protests continue demanding a more fair society and democratic government.

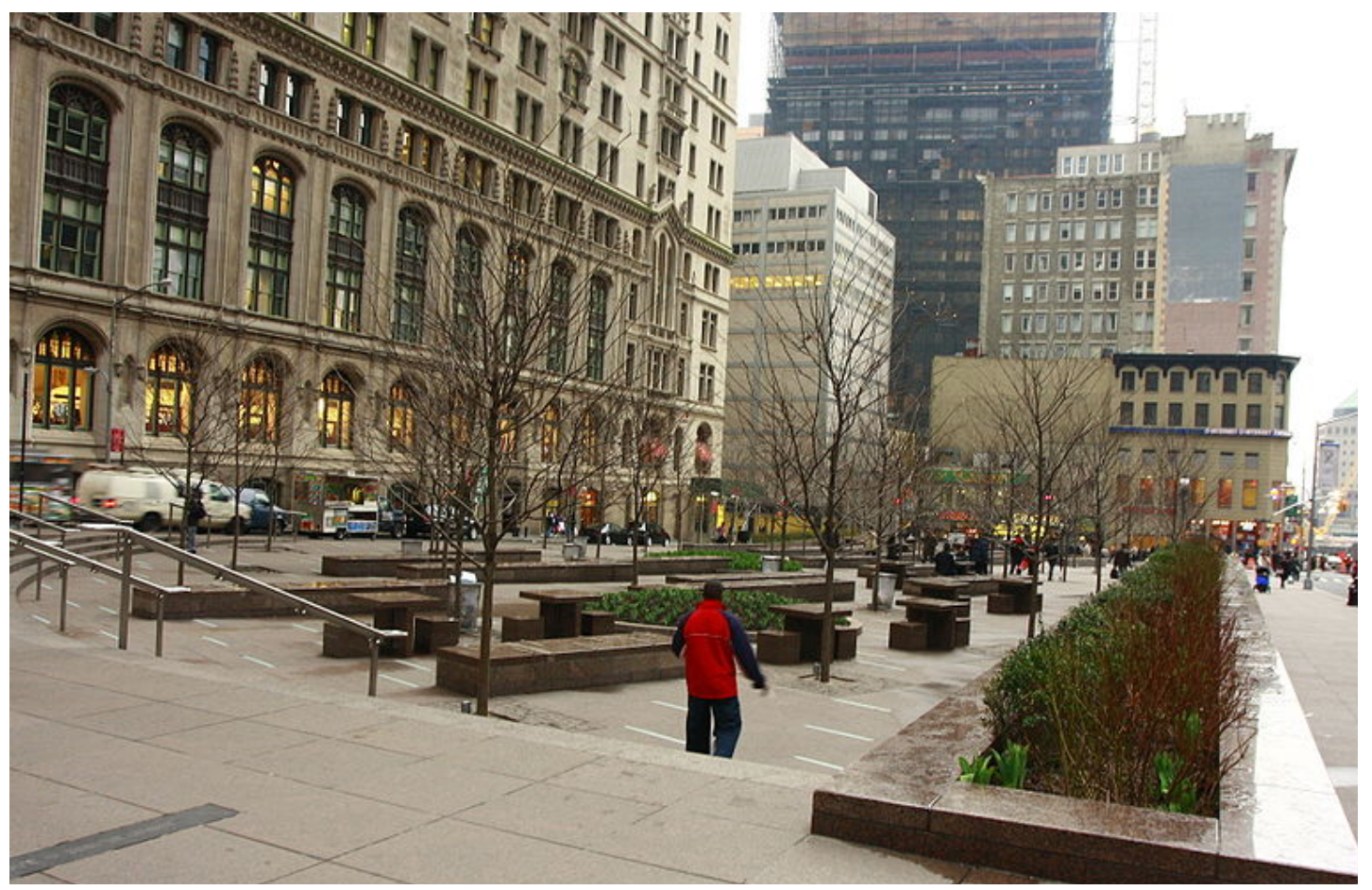

Figure 7: Zuccotti Park, New York City, as made famous by the Occupy Wall Street movement in 2011 (creative commons)

Spurred on by this Arab Spring, the Occupy Wall Street movement began its strategy in fall 2011 by occupying Zuccotti Park in New York City, a privately owned public space near Wall Street (see Figure 7). Emphasizing economic inequality, the housing crisis, and bank bailouts of 2008, protestors camped in this space and spurred the creation of hundreds of other occupations in parks and plazas around the world. In Portland, the Occupy encampment was located at Chapman and Lownsdale Square Parks on two blocks in the downtown district, the site of other mass protests in the city's history (see Figure 8). The Urban Center Plaza was also a 
site for the Occupy Portland State group's inaugural gathering or General Assembly, the only political democratic gathering I observed in this space.

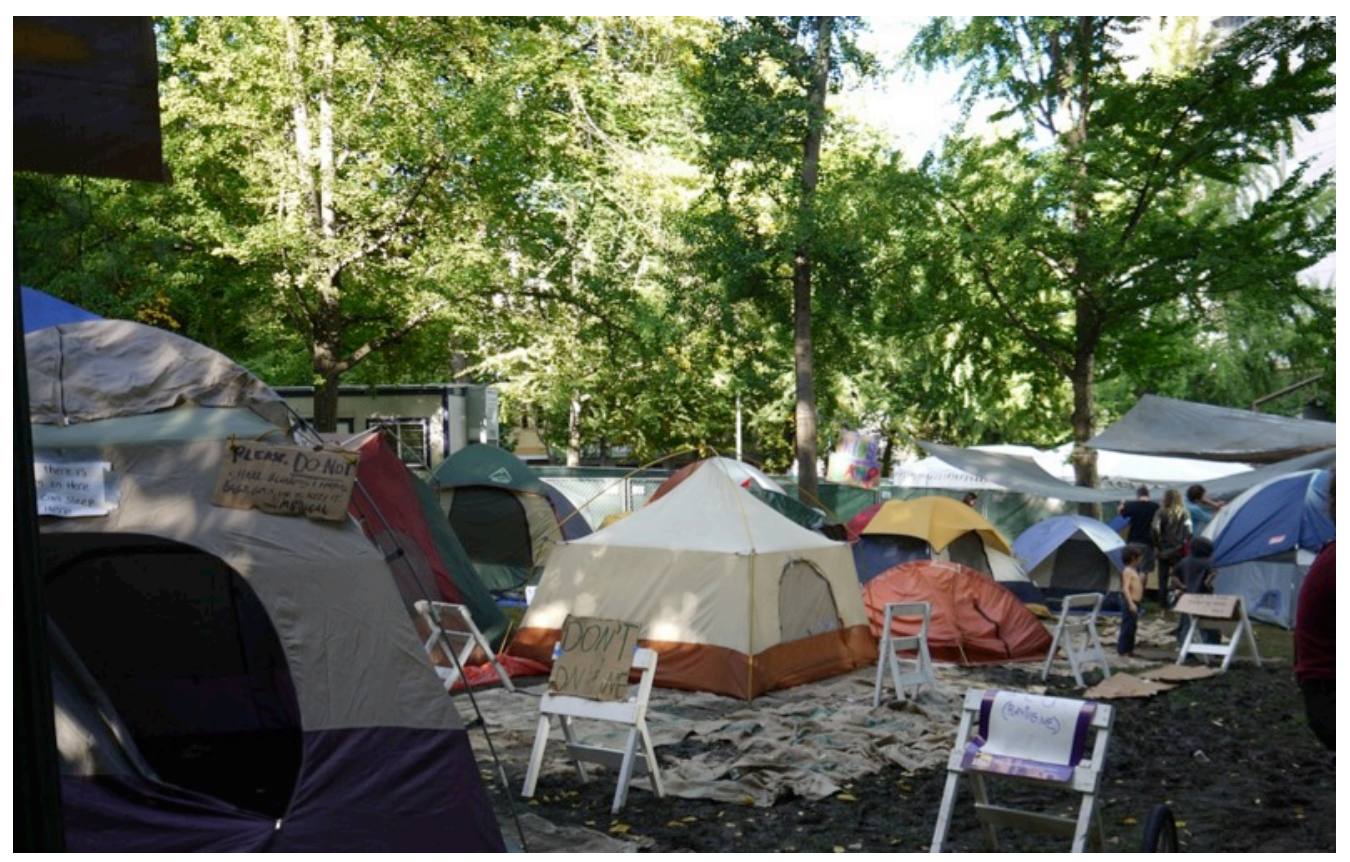

Figure 8: Occupy Portland Camp at Chapman Square Park (photo by author, 2011)

The conflict that arose regarding the right to assemble in these public spaces became a rallying cry for the protestors and raised questions about the 'publicness' of public space, as is also discussed in the scholarly literature (Nemeth, 2009; Tiesdell \& Varna, 2010). In most cities, protest camps were forcibly removed by city governments citing curfew laws and anti-camping ordinances despite protestor's arguments for civil disobedience and the right to free speech and assembly. From a social justice perspective, this may have a greater significance on our society than it may appear (Marcuse, 2012). Further protests were also put on to specifically raise awareness of these anti-camping bans and curfew laws placing restrictions on the use of public space. 


\section{The Right to the City}

Don Mitchell is perhaps one of the most influential proponents of public space as a form of true democracy through public representation and occupation of space. His argument is that rights, as part of the democratic process, are inevitably tied to space due to the numerous historic and contemporary examples of societal change through protest like the events listed above (Mitchell, 2003). Most protests of this kind are composed of individuals expressing a need for change, to improve a system which creates repression of some kind.

Despite the right to protest we currently have in a democratic society, there are still populations that have very little voice even with the appropriation of public space, like the homeless. In many cases, as with the advent of privately owned public spaces (POPS), places like plazas may only seem public but are actually regulated by private corporations or management companies or simply controlled by city-level regulations which purge certain undesirable peoples or activities out of the public eye. Mitchell (2003) emphasizes the need for true public spaces for those who otherwise have no voice, those who have no impact unless physically represented, and for those who have no private spaces in which to conduct otherwise private activities. The ability to alter our own environments, as part of the right to the city, is therefore necessary for the betterment of society as well as ourselves.

\section{Restricted Space}

In the strictly controlled average contemporary city, in conjunction with zoning codes and homeowners associations (HOAs), we see evidence of Mitchell's 
criticism in things like curfew laws - even in public parks and plazas owned by the city. Despite the lack of a prominent plaza culture here in the United States unlike many European and Latin American cities (Fusch, 1994; Low, 2000; Richardson, 1982), the inability to affect or control our public spaces in various ways is limiting choice and potential. Hou's (2010) arguments surrounding insurgent public space, the manipulating of the environment - often illegally - to the needs of the users, has been key for community building or even beautifying of space (as is the case with guerilla gardening). Relatively harmless interventions in public space like yarnbombing, the addition of crocheted bits of yarn typically around things like bicycle racks or poles, can even add joy and create a sense of place (see Figure9).

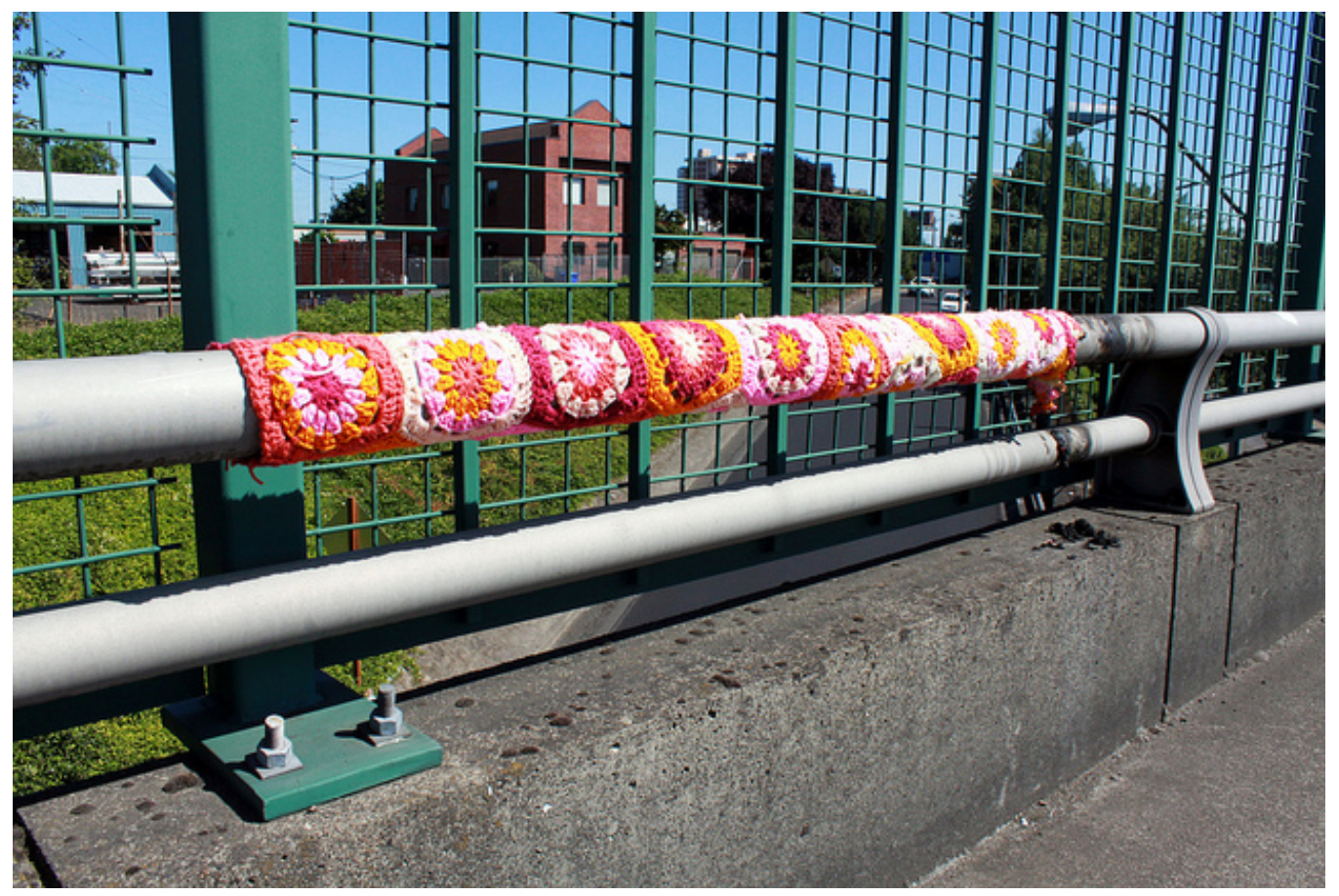

Figure 9: Though technically illegal, “yarn-bombing” in Portland helps create a sense of place (photo by Tiffany Conklin, used with permission)

In many cities in the U.S. parks and plazas close between the hours of 10:00 PM and 5:00 AM thereby keeping out undesirables who are forced to sleep outside, 
or housed individuals simply wanting to enjoy a late evening in a park. Restrictions may make it illegal to consume alcohol, sleep on benches, skateboard, bicycle, rollerblade, post notices, loiter, camp, gamble, play music, block entrances/exits, interact with water features, walk on the grass, or even remove items from trashcans - notably many activities carried out by homeless populations. Some also cite the lack of basic utilities for the public in these spaces such as access to public toilets and the human right to have access to them without having to buy something from a store (Molotch \& Noren, 2010). Playgrounds are sometimes restricted to certain age groups furthering the specialization of space.

After the Occupy Wall Street movement's occupation of space, many privately owned public spaces, including Zuccotti Park, tightened restrictions even further (see Figure 2). Though permits typically allow some of these otherwise disallowed behaviors, there are still restrictions on which things are allowed, where, and for how long. In some cases a payment is even required to publicly assemble.

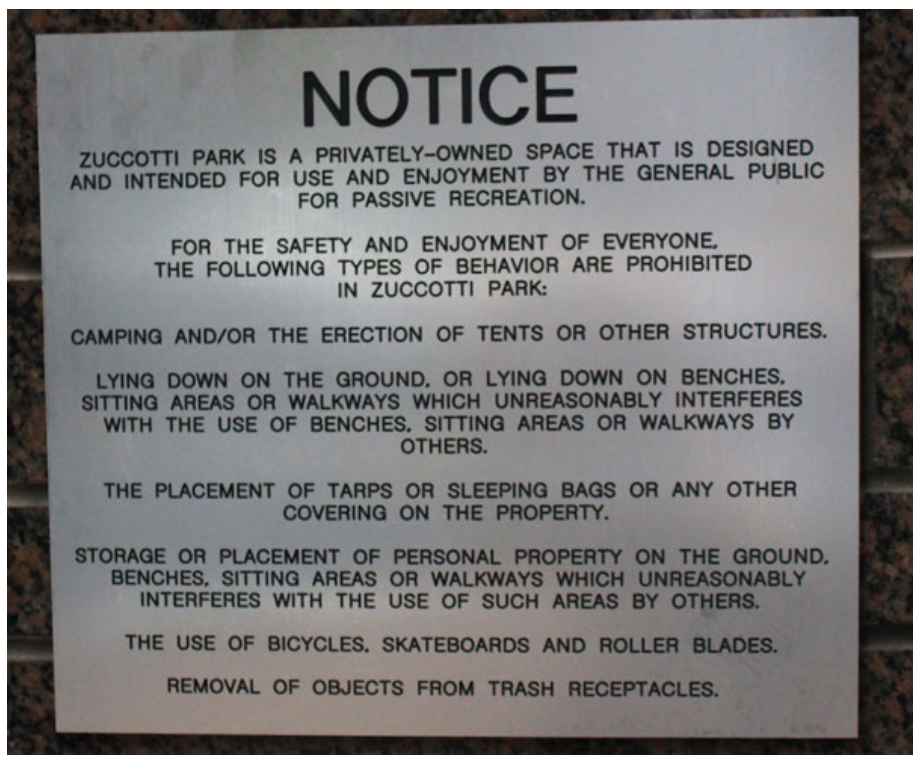

Figure 10: Prohibited Behavior in Zuccotti Park, New York City (Reynolds, 2011). 


\section{"Good" Public Space}

There are many theorists who value public space for not only social justice reasons but also for health reasons regarding social, political, and physical wellbeing (for urban residents in particular). One of these benefits, though slightly controversial, is the "contact hypothesis" which argues that socio-spatial contact amongst members of different ethnic and class groups benefits citizens in that they experience ways of life foreign to their own and therefore broaden their tolerance and understanding of people in general (Hajer \& Reijndorp, 2001; Sennett, 1990).

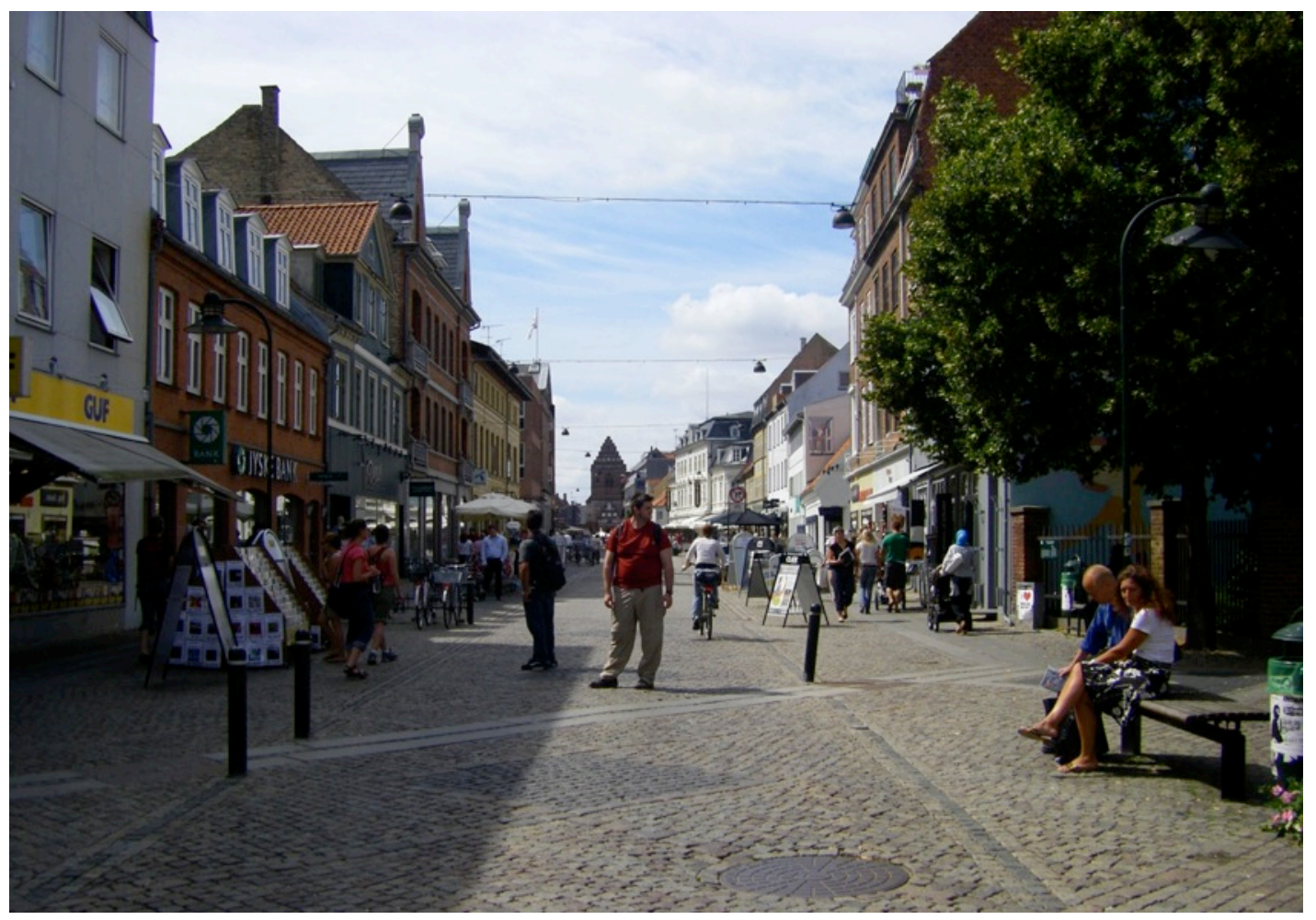

Figure 11: Strøget, Copenhagen, an extremely popular pedestrian street (photo by author, 2008)

In Sweden during the 1930s, the park reform was seen as crucial to rehabilitating a country in crisis and the emphasis on public living spaces in cities is still a key component to their culture's high quality of life (Andersson, 2008). The 
New Urbanist movement aims towards creating a form-based code for buildings, as well as the spaces between them (Duany, Plater-Zyberk, \& Speck, 2001). Numerous guides have also been created in order to explain these principles of good design emphasizing the human element (for examples, see: Francis, 2003; Gehl, 2010; Krier 2009).

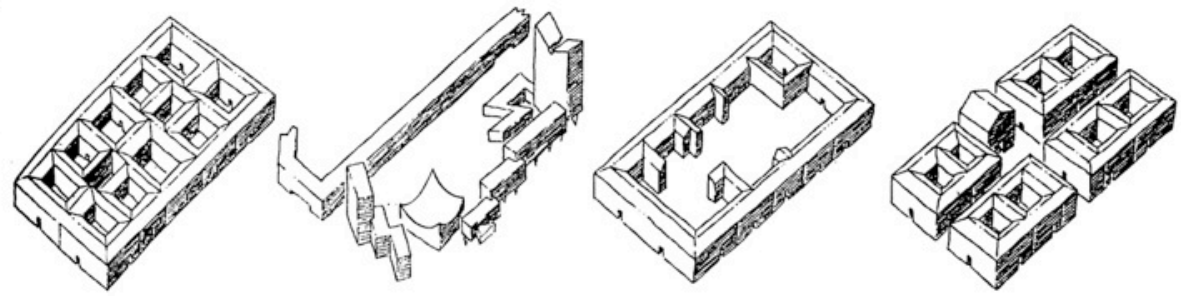

\section{RIRATIVE WUANIIIIY of PUBLIC SPACE}

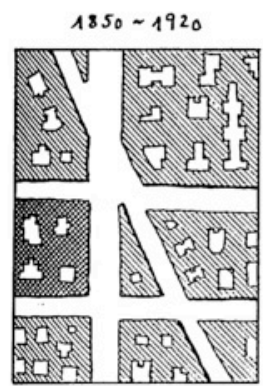

$15 \sim 20 \%$

TOO LITTLE PUBLIC SPACE

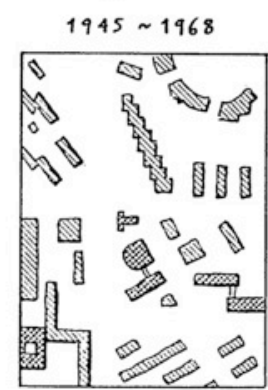

$70 \sim 80 \%$

TOO MUCH PUBLIC SPACE

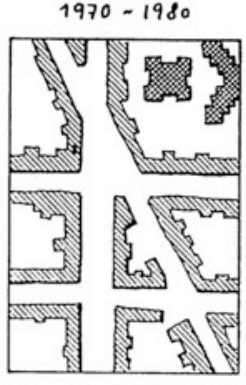

$50 \sim 60 \%$

TOO MUCH SEMI-PUBLIC

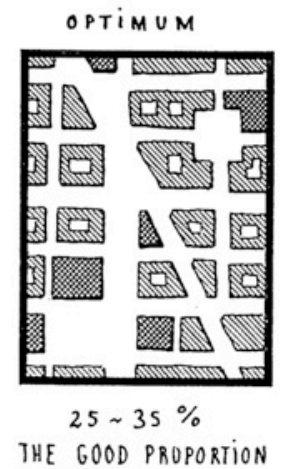

Figure 12: Leon Krier's definition of good public space (Krier, 2009)

Famously, Jacobs (1961) argues for high-quality, interactive, and pedestrianfriendly environments in neighborhoods where one can form connections between members of the community and increase joy, as well as safety, in the city. Her "eyes on the street" concept creates a safer environment through the notion that the more people there are, the less likely severe crime will take place because it is less likely they will "get away with it". This is also applied to Whyte's seminal research on parks and plazas in New York City. He found that places which do not have people 
tend to continue not having people and attract "deviant behavior", and the biggest attractor of people, and therefore safety, is in fact other people (Whyte, 1990).

An excellent example of what is frequently deemed a "good" public space is one which was altered by Whyte based on his research - Bryant Park in New York City (Whyte, 1990). Originally, Bryant Park contained many of the physical features which allowed for high levels of crime and low levels of usage. A historic wroughtiron fence surrounded the park leaving only a few gaps for entering or exiting. Within the park were overgrown bushes and shadow-casting trees which provided many hiding spots for muggers and drug dealers. There was also no attraction which would create a steady flow of people in and out of the park to assist in safety issues.

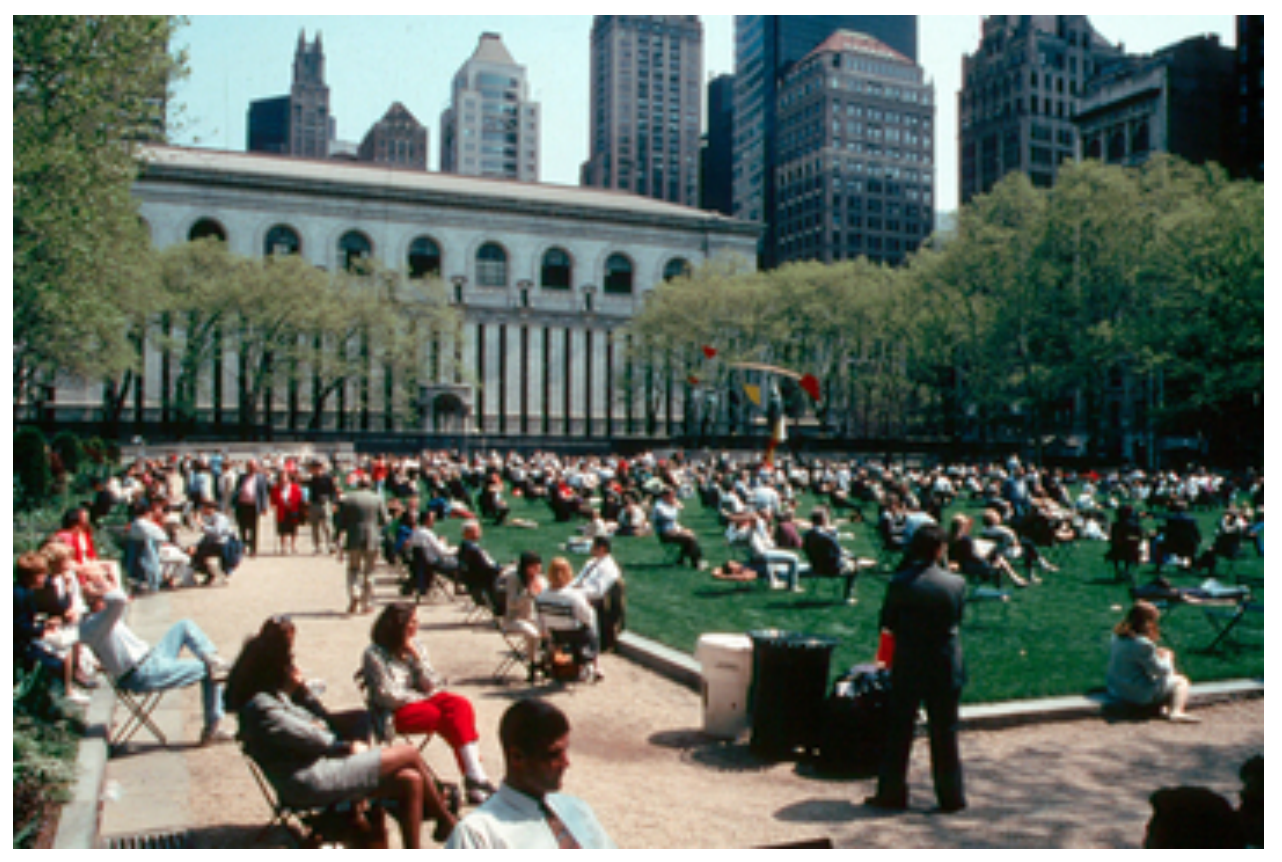

Figure 13: Bryant Park, redesigned in 1981, is still extremely successful (Kent, 2012)

Whyte, utilizing his research, worked with the city and architect Laurie Olin to transform this space into one of the safest and most attractive destinations in New York (Kent, 2012). The bushes and unruly trees were removed, a large open 
green space with movable chairs was added to the center of the park, and two attractions - a small coffee stand and a larger café-bistro - were created on both ends of the park to bring people in. A public-private partnership was also created which allowed for private maintenance of the park's flora, thereby adding an informal sense of security and general assistance in the form of friendly park managers. Decades later it is one of New York City's most celebrated spaces.

The Simon and Helen Director Park in downtown Portland, Oregon, follows this model in many ways, in part because it was designed by the same person Laurie Olin (“OLIN: blog," 2012). This grey space park sits on 0.46 acres over 700 underground parking spaces and was completed in 2009 (see Figure 14) ("Portland Parks \& Recreation:: Simon \& Helen Director Park," 2012). It incorporates many of the design principles lauded by Whyte. A small café sits in one corner of the space attracting people indoors and outdoors to a designated alcohol appropriate section of patio as well as the rest of the plaza where movable chairs dot the space. Public restrooms in the form of single-units open to the outdoors with frosted glass doors and slight gaps to allow for light monitoring of activity by the park's manager (whose office is adjacent). 


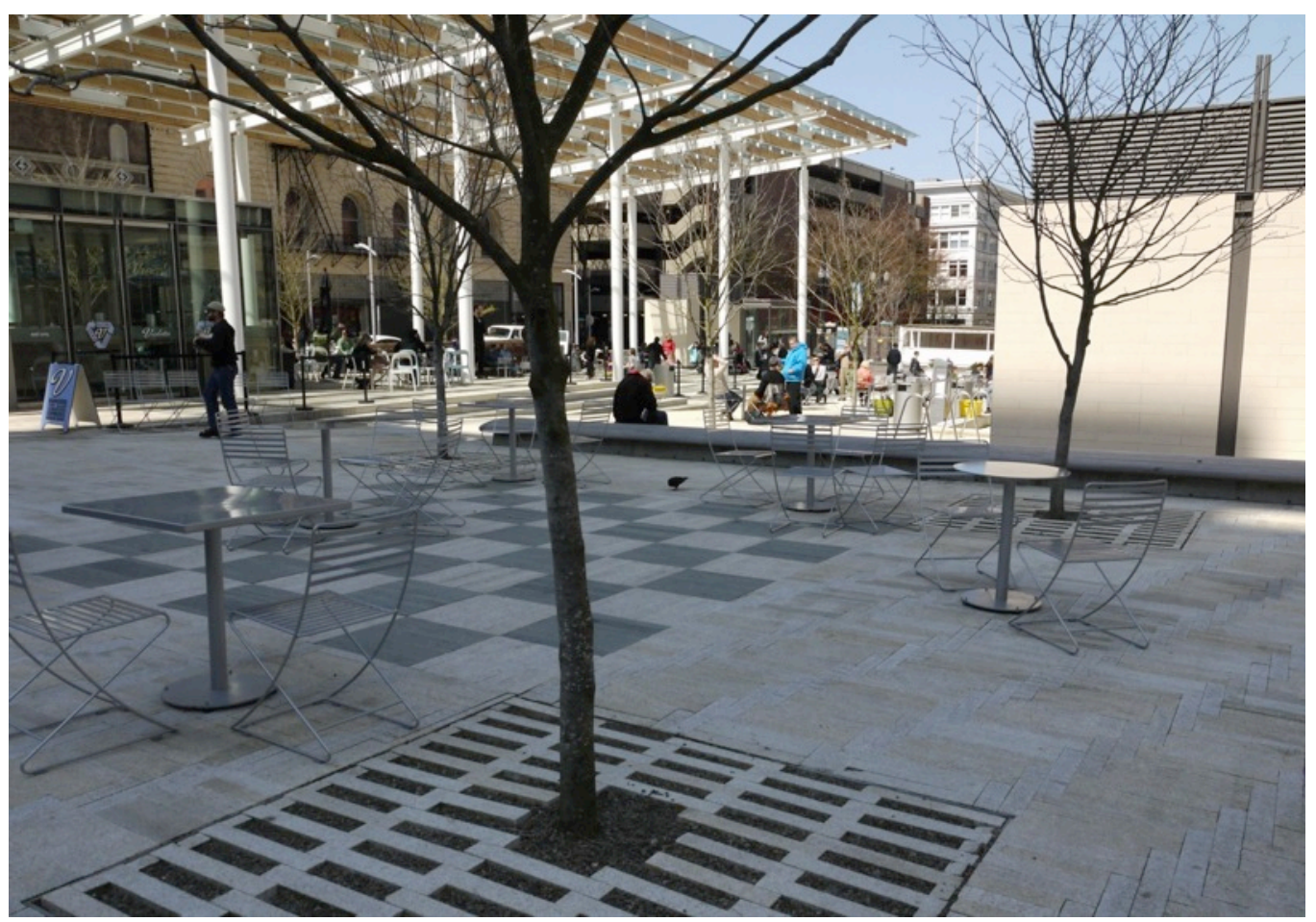

Figure 14: Director Park, 2011, large-scale chess board section of the plaza with café to the left and wading pool in the background (photo by author)

The space is mostly street-grade and is divided into various usages including a water feature where interaction is greatly encouraged, a covered glass section for protection from the rain (and slight diffusing of the sun's rays), and a large-scale chess board in the pavement designating another corner surrounded by large hardwood benches. The combination of programmed and non-programmed activities, a variety of unique places within the space, and the overall visibility and management create an extremely enjoyable and safe space to be in.

When looking at these successful spaces, one can extrapolate various design features that have contributed to the popularity of place (see Table 5). Some of it is management oriented, some design specific, but all of it is geared towards creating the ideal space for urban residents. Some principles are also very basic and easily 
adaptable to other environments. If "people like to sit where there are places to sit", as Whyte notes, it stands to reason that an otherwise empty space may be enhanced

by the addition of movable chairs (Whyte, 1990). A simple concept to be sure, but

one which is necessary to consider when analyzing other spaces.

Table 5: Design \& Management Recommendations for Public Open Space

Uses and Activities

- $\quad$ Provide amenities that will support desired activities.

- $\quad$ Create focal points where people gather.

- Develop a series of community-oriented programs with local talent from institutions (churches, schools, libraries, farmers markets, and so forth) to attract people in the short term and to demonstrate that someone is in charge.

- $\quad$ Change the type of events that are held or modify the space, if necessary, to better accommodate events.

- Work with adjacent property owners and retailers to develop strategies to lease ground floors of empty buildings and help revitalize the area.

Comfort and Image

- $\quad$ Add practical amenities - seating, telephones, waste receptacles, information booths, food vendors, community-oriented public art, flowers, fountains - in carefully considered locations.

- $\quad$ Create a management presence through vendors or food and information kiosks by creating an entrance or adding a view on to the place from windows in an adjacent building.

- Increase security by providing more uses for activities at the place, which will increase the number of people present, or by appointing an individual to be in charge of security.

- $\quad$ Upgrade maintenance, including daily cleaning, and preventive maintenance of physical facilities.

- $\quad$ Establish a community-policing program.

Access and Linkages

- Widen sidewalks or provide sidewalk extensions at crosswalks, better balancing pedestrian uses with other uses (vehicles, transit vehicles, bicycles, deliveries, and so forth).

- $\quad$ Construct clearly marked and/or conveniently located crosswalks.

- $\quad$ Make accommodations for bicycle users (bike lanes, lockers, storage racks, etc.).

- Infill vacant lots with structures and uses to create continuity of pedestrian experience.

- $\quad$ Balance on-street parking with other uses.

- $\quad$ Change traffic signal timing to improve pedestrian access.

- $\quad$ Improve use of parking through changes in enforcement or regulation.

Sociability

- $\quad$ Develop focal points-public gathering places that accommodate a variety of activities.

- Arrange amenities to encourage social interaction, such as grouped benches and movable seating.

- $\quad$ Stage special events and activities to draw people.

- Encourage community volunteers to assist with improvements or maintenance of a place.

- $\quad$ Provide a variety of uses in adjacent building to attract a diversity of people.

Found in Francis, 2003, p. 69, originally in How to Turn a Place Around, 2000, p. 86-93 


\section{Similar Research Studies}

When analyzing public spaces, the primary source of similar research is in Whyte's seminal study of New York City's parks and plazas (Whyte, 1980, 1990). By conducting a detailed observation of numerous public spaces in the city, Whyte was able to better inform city officials and policy makers about the principles of good urban design for people. As his research was conducted in the 1970s and 1980s, his aim was also to attract people back to the urban center at a time of suburban sprawl. By utilizing photography, video recordings, direct observations, interviews, mapping, and pedestrian counts, Whyte was able to provide a thorough analysis of New York City's spaces, it's characters, and what it needed physically to be a better place. He also made it a point to include comparative observations he made in other places like Dallas, Texas and Tokyo, Japan. Ultimately his research did lead to better design for the infamous bonus plazas, the redesign of several parks and plazas, as well as general principles of good public space.

Some of his behavioral observations have become common concepts when describing behavior in public space. One of the most famous general principles is the "100 percent conversation" where people tend to pause for conversation at street corners or in front of doorways where it is least convenient for the flow of traffic. Another pattern frequently observed during a 100 percent conversation is the "prolonged goodbye" which describes the action of two people saying goodbye once, then twice, and even three times before leaving each others' presence. In a truly ethnographic fashion, he was also able to find commonalities in the types of people 
who frequent the public sphere, giving them such labels as Schmoozers, Girlwatchers, Lovers, and Street People. The patterns of these various typologies were crucial to understanding the use of space and public behavior.

The technical aspects of his research included recording certain streets and plazas for two weeks at a time and analyzing the video later for precise pedestrian counts and pause locations. He also observed seating areas and mapped where pedestrians sat along a stretch of space, looking at where people sat and for how long. Whyte found that people tend to space themselves in dense groups close to where other people are already sitting. His suggestions included the increase in provision of seating, better designed street furniture (such as trash-cans, which are multi-purpose), and human-oriented sizes of stairs and sidewalks. The Project for Public Spaces headed by Fred Kent, Whyte's former assistant, now continues the concepts of his research ("Project for Public Spaces - Placemaking for Communities," 2011).

Low's approach to analyzing public plazas in Latin America and elsewhere takes a more qualitative ethnographic and phenomenological focus while observing a space over time (Low, 2000). By using history, literature, direct observations, informal interviews, and personal narrative, she provides an accurate description of socio-political issues of space in these specific locations. Low's methods are that of a skilled ethnographer, but do not necessarily provide a quantitative component to her research.

Mehta's work utilizes surveys, interviews, pedestrian counts, and observations in order to analyze successful public space in Cambridge, 
Massachusetts (Mehta, 2008). However, it is Jan Gehl's recent and continuing work that is perhaps most closely representative of a contemporary Whyte-like method. Gehl Architects, based in Denmark, has been involved in many projects worldwide that begin with thorough spatial ethnographies in order to analyze the space and create the best solution for that location.

Gehl's primary focus, like Whyte, is in the human element aspect of urban design (Mehta, 2008). He conducts pedestrian and bicycle counts, but also considers human-oriented perspectives based on the physical parameters of the human body (see Figure 15 for an example). One of the primary arguments for encouraging bicycle commuting is the fact that while on a bicycle, one can more easily see or even touch the other person also on a bicycle or walking nearby. This is in contrast to automobiles whereas more space and material, and often lack of visibility, separate one person from the other and decrease the theoretical and physical connection leading to a less interesting, connected, and healthy urban environment. 
senses and tall buildings
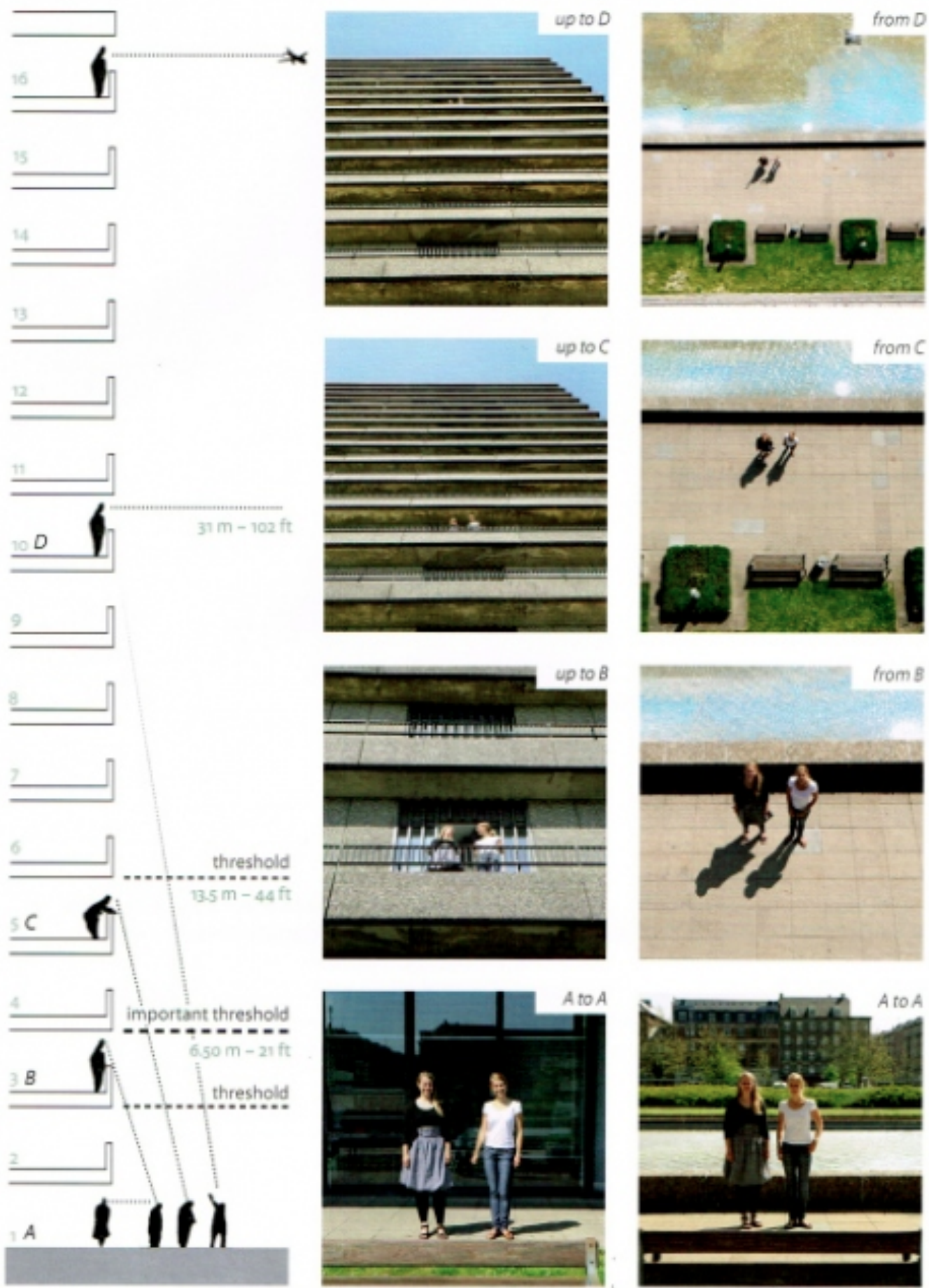

Figure 15: Jan Gehl's human dimension, the contrast of the human capability for perspective and recognition (Gehl, 2010; p. 40) 


\section{Previous Research on the Urban Center Plaza}

In the summer of 2004, a group of students at Portland State University conducted a research project as part of a Capstone course in the School of Urban Studies and Planning (Blank et al., 2004). Influenced by Whyte's methods and the Project for Public Spaces, these students took a comparative look at this plaza in order to analyze why it appeared to be less successful than other Portland parks and plazas. They used time-lapse photography from Tuesday July $27^{\text {th }}$ to Thursday July $29^{\text {th }}$ and the following Tuesday through Thursday on August $3^{\text {rd }}$ to $5^{\text {th }}$. Between the hours of 10:00 AM and 4:00 PM they recorded the upper plaza specifically for staying activity and behavior. They also conducted intercept surveys on people exiting the plaza in order to discover how the plaza is used, frequency of use, and what users would like to see changed. An experiment was then conducted during the second week to see if the introduction of tables and chairs to the upper plaza would attract more "staying" activity in what appears to be an otherwise transitory space. They also held and event in the plaza on the last day in an attempt to attract more people.

Results showed that there was an increase in the time people spent in the plaza during the second week when tables and chairs were introduced. Out of 309 people surveyed in the five days surveys were carried out, a third came to the plaza daily and most came for classes. Others came for food and beverages and to visit the Portland State University Bookstore located on the ground floor of the adjacent Urban Center building. Most reported using the space for simply passing through, however, or to eat and relax. In terms of suggestions, the most commonly referenced 
additions were shade (notably from surveys conducted on the hotter days), more street furniture, vegetation, and activities.

Their original hypothesis was that the plaza appeared to be barren and underused, especially in comparison with other Portland public spaces like Pioneer Courthouse Square and Jamison Square (located in the Pearl District in Portland). In conclusion, they argued their results affirmed this suspicion and suggested alterations to the plaza to remedy this. Based in part on the surveys, they suggest adding protection from the elements, tables and chairs in other areas (not just near the restaurants on the lower plaza), trees and vegetation, and activities to draw people to the space and keep them there.

At the time of their study, the plaza was in the second phase of development (see Figure 19). In the second phase, the only difference to the first phase was the addition of the streetcar tracks through the plaza. The Recreation Center was not constructed, light rail was not nearby, and the stormwater retrofit had not yet been done. Eventually the space would be a more important transit hub, provide an entrance to the Recreation Center, and contain some green space.

Considering the scenario at the time of analysis, the differences between the two time periods must be taken into account when comparing results. For example, there were those who used the plaza who suggested the addition of more vegetation, which did eventually happen. Also, it is possible that the addition of a much larger adjacent building than what was there at the time may assist in adding the shade that was requested as well, though this doesn't assist in shelter from the rain. The limited time and type of observations are also a potential issue. However, 
their conclusion that the plaza is used mostly as a transitory space and continued criticism of that today is something to note. Further commentary on comparing the data sets will be covered in a later section. 


\section{Chapter 3. Urban Center Plaza Research Project \\ Research Design and Project Goals}

As one of the most important components of cities, there is a need for ongoing research into the open spaces of the city, their creation, use, and management, which takes into account the variation in types and use. Methods of analyzing public space frequently utilize observation, either video, in person, or a combination of the two. This thesis uses a mixed methods approach of quantitative and qualitative methods in order to construct an ethnography of place. These methods are described below and are based on the work of Whyte, Low, Gehl, and Mehta (Gehl, 1987; Low, 2000; Mehta, 2008; Whyte, 1990).

As stated previously, the research goals were to explore:

1. The history of the Urban Center Plaza.

2. How people use the Urban Center Plaza.

3. What, if anything, has changed in seven years based on previous research at the Urban Center Plaza focusing on behavior and attitudes associated with the Plaza.

4. How these research methods in particular can shed light on human behavior in public space for future analysis and improvement of urban design for open space.

In order to achieve these goals, methods were organized in varying ways, incorporating qualitative and quantitative methods depending on the research question. Table 6 shows the methods used according to the stated goals. Originally, proximity to the plaza allowed for interaction with the space and opinions on its design were formed. This was followed by analyzing previous research on the Urban Center Plaza that had been done by a Capstone course several years earlier, a culminating class required for meeting the requirements for a bachelor's degree. 
Direct observations of the plaza were conducted after human subjects approval and continued for the duration of the study. Randomized video observations were planned in order to provide pedestrian counts and a quantitative component to behavior in space. In order to more fully understand how the plaza was designed and why, interviews were conducted with key players in its design and construction to analyze its present state in a historic context. Originally, intercept interviews were planned for users of the plaza, though the research design was later altered for several reasons. Results were analyzed and compared with previous research of public space as well as the Capstone course's findings.

Table 6: Overview of methods used per research question

\begin{tabular}{|c|c|c|}
\hline Research Method & Time Span & $\begin{array}{l}\text { Research Questions } \\
\text { Addressed }\end{array}$ \\
\hline $\begin{array}{l}\text { 1. Direct in-person } \\
\text { observations }\end{array}$ & $\begin{array}{l}\text { Continuous post-approval of } \\
\text { proposal }\end{array}$ & Goal 2 \\
\hline $\begin{array}{l}\text { 2. Video recorded } \\
\text { observations }\end{array}$ & $\begin{array}{l}\text { Fifty hours of randomized } \\
\text { observations over two weeks }\end{array}$ & Goals 2,3 , and 4 \\
\hline 3. In-depth interviews & Over course of two weeks & Goals 1 and 3 \\
\hline $\begin{array}{l}\text { 4. Capstone course material } \\
\text { analysis and comparison }\end{array}$ & $\begin{array}{l}\text { Continuous post-approval of } \\
\text { proposal }\end{array}$ & Goals 1,3 , and 4 \\
\hline 5. Intercept surveys* & Randomly during several days & Goal 3 and other removed goal \\
\hline
\end{tabular}

History and Overview of the Urban Center Plaza

Before the creation of the Urban Center Plaza, SW Montgomery Street continued through the two 200-feet blocks (see Figure 1). As part of then Dean Toulan's initiative, this region of downtown Portland, east of the main campus centered around the south park blocks, was the region of a University District planned to connect the campus to the rest of the city and expand the growing school. The University also didn't have any newer buildings for classes and offices, so this 
project was intended to lay the groundwork for a modern university and the acclaimed urban studies and planning program (Toulan, 2012). A master planning process for the surrounding six blocks began in 1996, led by THA Architecture with Walker Macy Landscape Architects. As part of the University District, the goals for the Urban Center and Plaza were as follows (Portland Development Commission, 1999; see Appendix H for full report):

1. Make a vibrant urban place that connects Portland State University to the City.

2. Create a symbolic "front door" for the University within the city.

3. Make an exceptional setting for teaching and learning.

4. Make an urban development that supports the vitality and economic success of the University District.

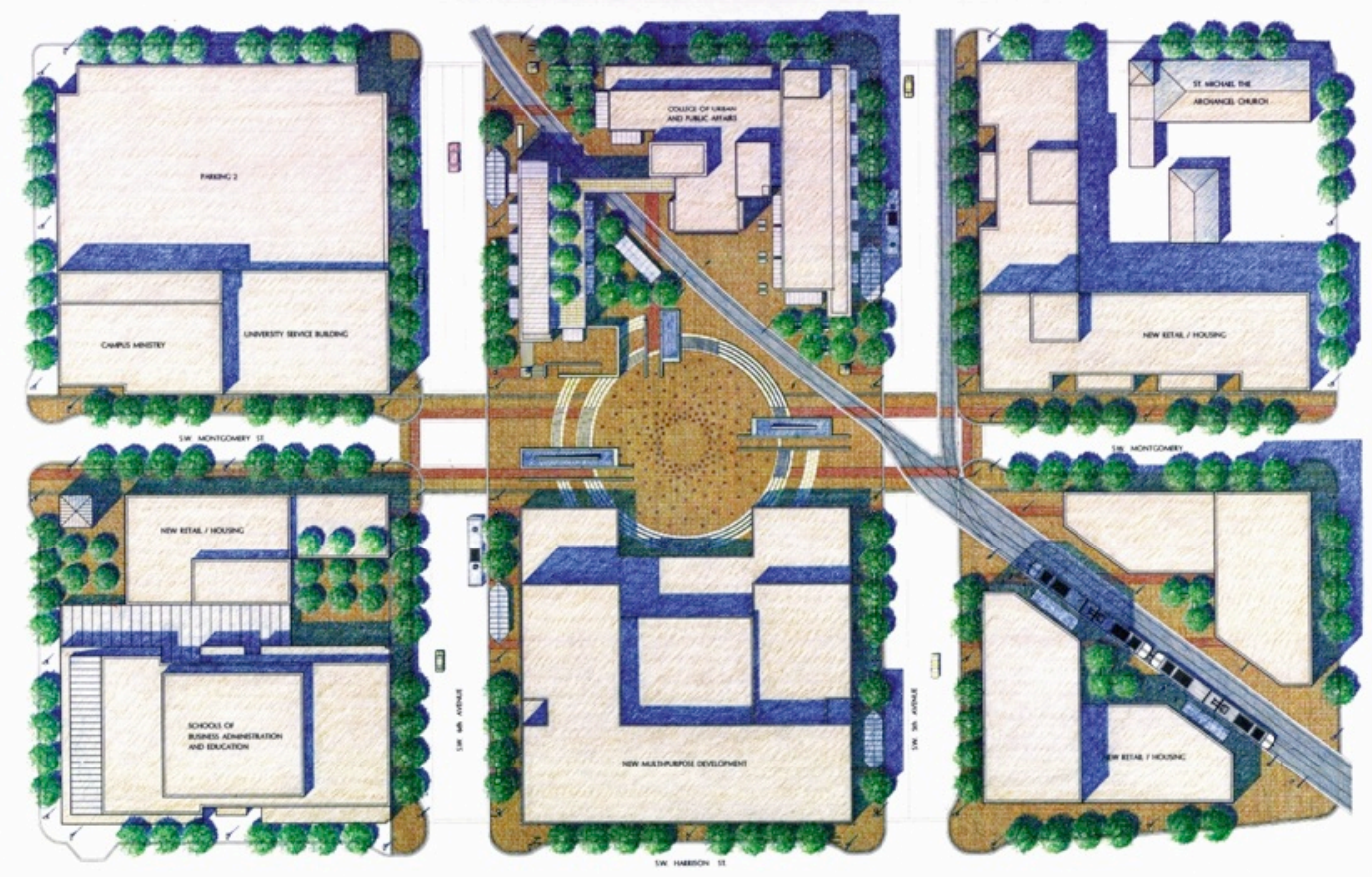

Figure 16: Original 6-block plan design of University District (Image by Doug Macy, used with permission)

\section{Phases of Development}

In order to understand the evolution of the Urban Plaza, its development is organized into five phases, from the original plans to its present-day design. 
Phase One: Walker Macy Design. Phase one began with the original design of the Urban Center Plaza lead by Walker Macy while THA Architects designed the Urban Center building, completed in 2000 (see Figure 19). Walker Macy had also been a part of the team that designed Pioneer Courthouse Square in downtown Portland (see Figure 17). The two spaces are actually somewhat close in size $(30,000$ sq. $\mathrm{ft}$. versus 40,000 at Pioneer Courthouse Square) and share some of the same design elements like tiered seating, a large space for events, and an emphasis on edges where trees and benches create intimate spaces away from lines of direct travel but close to services of interest.

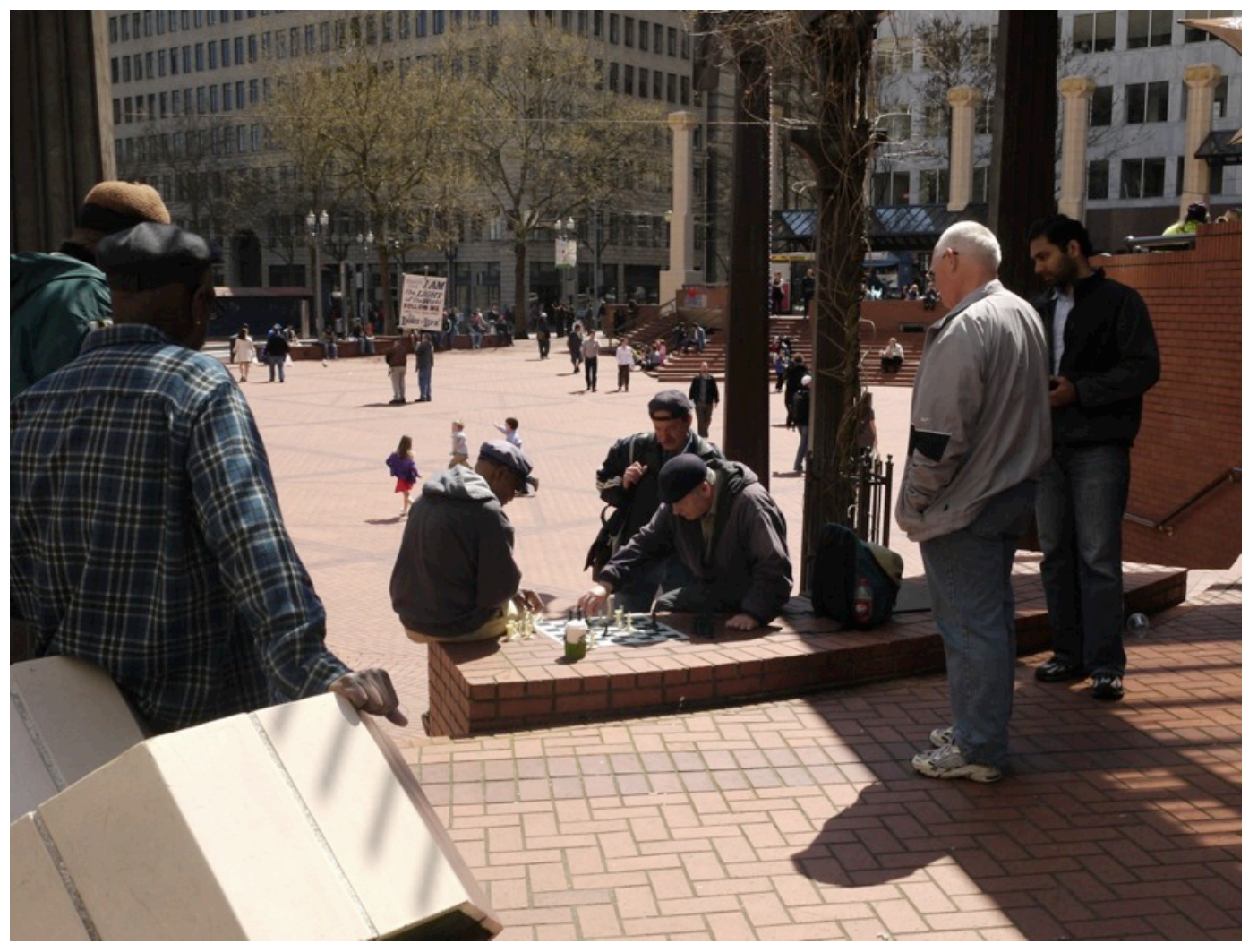

Figure 17: A game of chess in the intimate upper area of Pioneer Courthouse Square with the large open space and tiered steps in the background (photo by author, 2011) 
After construction of this first phase, the upper terrace of the Urban Center Plaza and the area in front of the Urban Center building was entirely gray space aside from the three water features. Due to the extreme grade change of this block (about 13 feet) and ADA requirements by the city, movement through the plaza is a multilayered process of either ramps or sets of stairs (see Figure 28). While it was being designed, there was a smaller building where the Recreation Center is now, but a larger building was planned for that location. Bus routes flanked the block on SW $5^{\text {th }}$ and SW $6^{\text {th }}$ Avenue, but no light rail was planned for this location yet.

Originally, light rail was planned to move through the plaza where the streetcar is now instead, in sunken tracks as is the case in the northwest corner of the entire plaza (see Figure 18). 


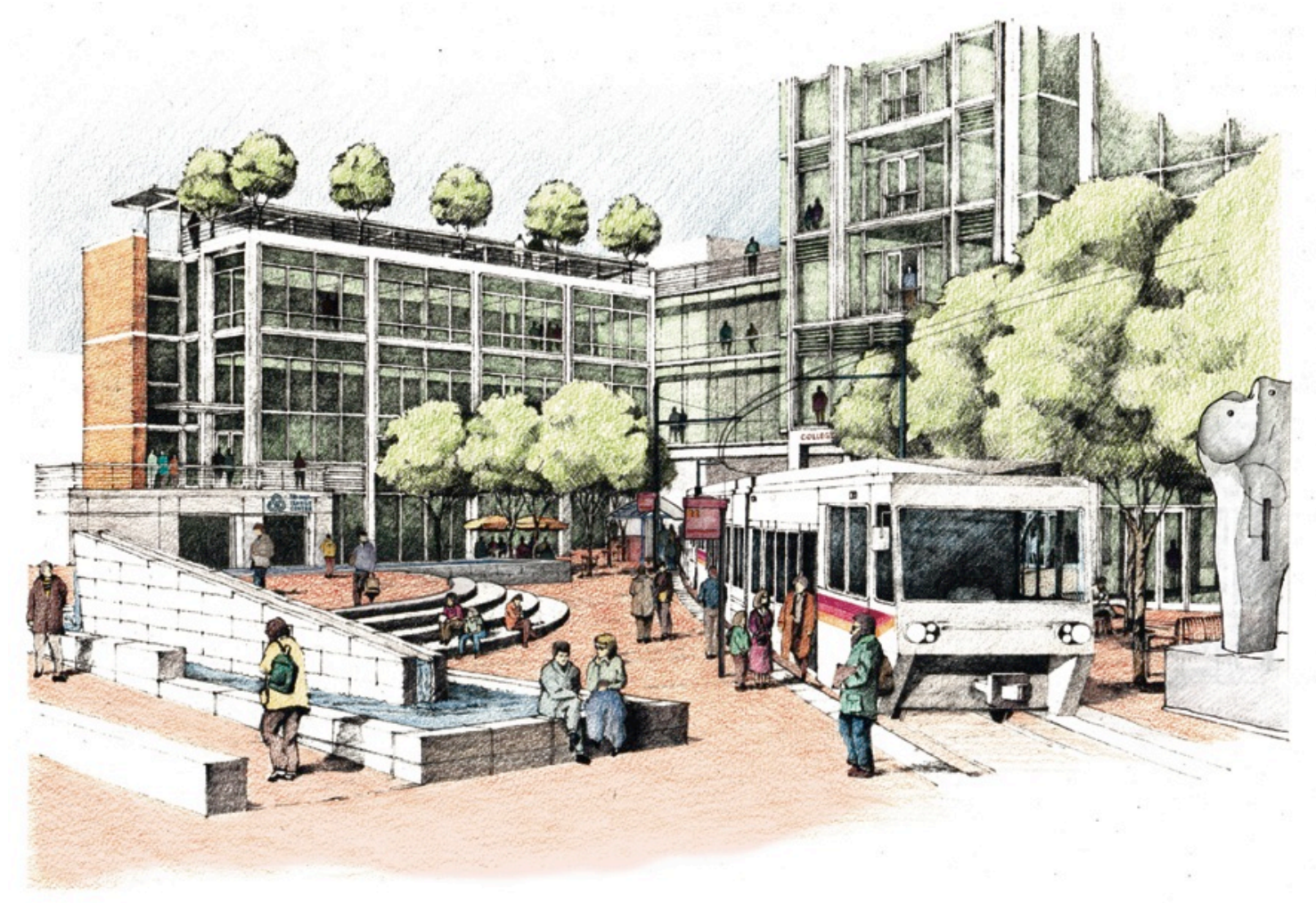

Figure 18: Early sketch of plaza including light rail moving through (image by Doug Macy, used with permission)

The dimensions and risks regarding such a large form of transportation were taken into consideration when designing the plaza and buildings (including the bridge between the buildings and street entrances), but after construction it was decided that the streetcar would take its place (Toulan, 2012). If light rail had moved through the plaza instead, it would be an entirely different place due to the larger and faster nature of the light rail versus the streetcar (Macy, 2012). Also during this time the upper terrace of the plaza was planned to be a complete circle, after the construction of a building on the south side of the plaza, facing the Urban Center building (see Figure 16). 


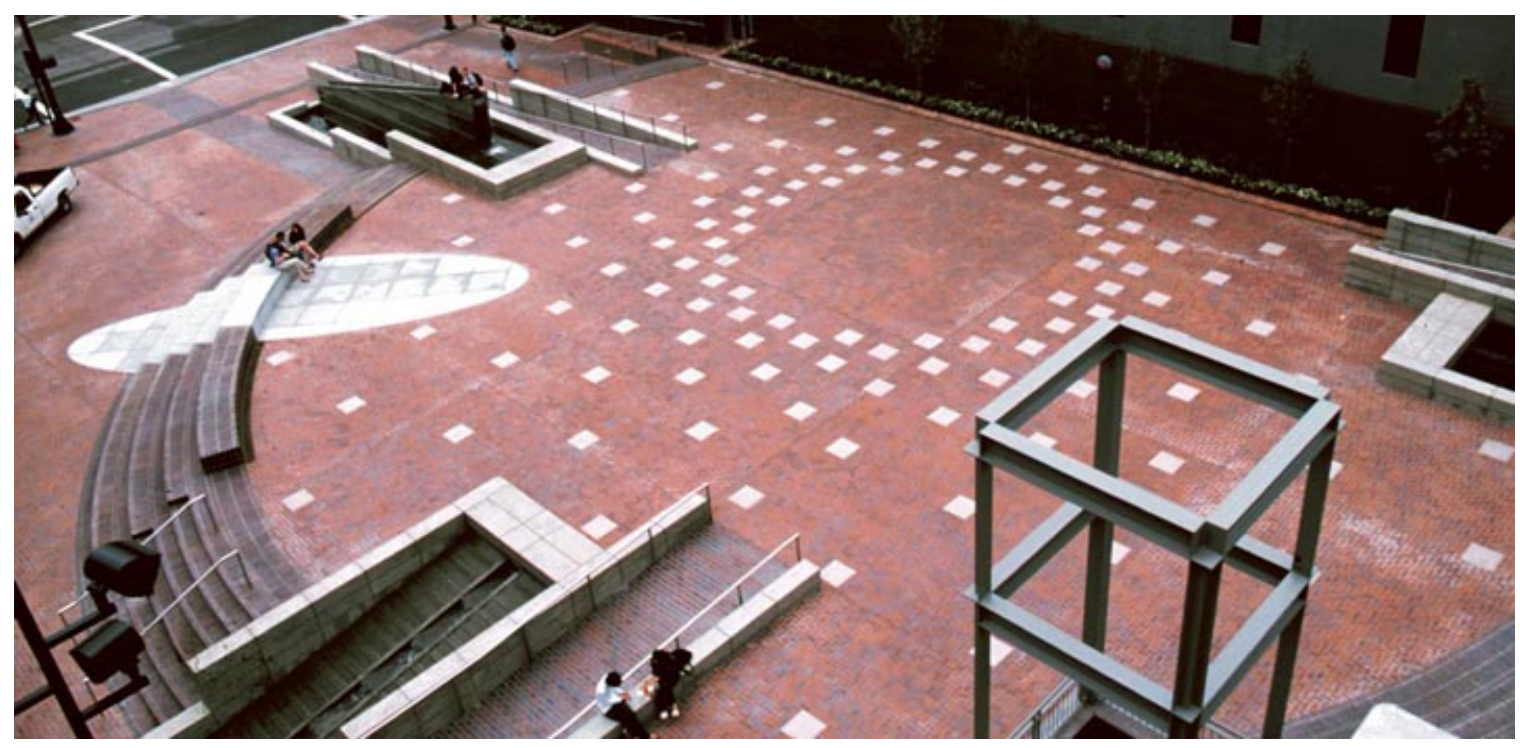

Figure 19: Phase one of the upper area of the Urban Center Plaza, before streetcar and Recreation Center building construction ("Walker Macy:: PSU Urban Center Plaza," 2012)

Phase Two: Adding the Streetcar. The second phase of development saw the streetcar bisect the plaza in 2001. The character of the plaza was somewhat altered by the streetcar because of the division of space, though this was a part of the original design. The celebration of the streetcar line and the beginning of service took place in the plaza (Macy, 2012). During this time, events like this, including graduation ceremonies for the College of Urban and Public Affairs, took place in the plaza, as was intended in the original design according to Macy (see Figure 20). 


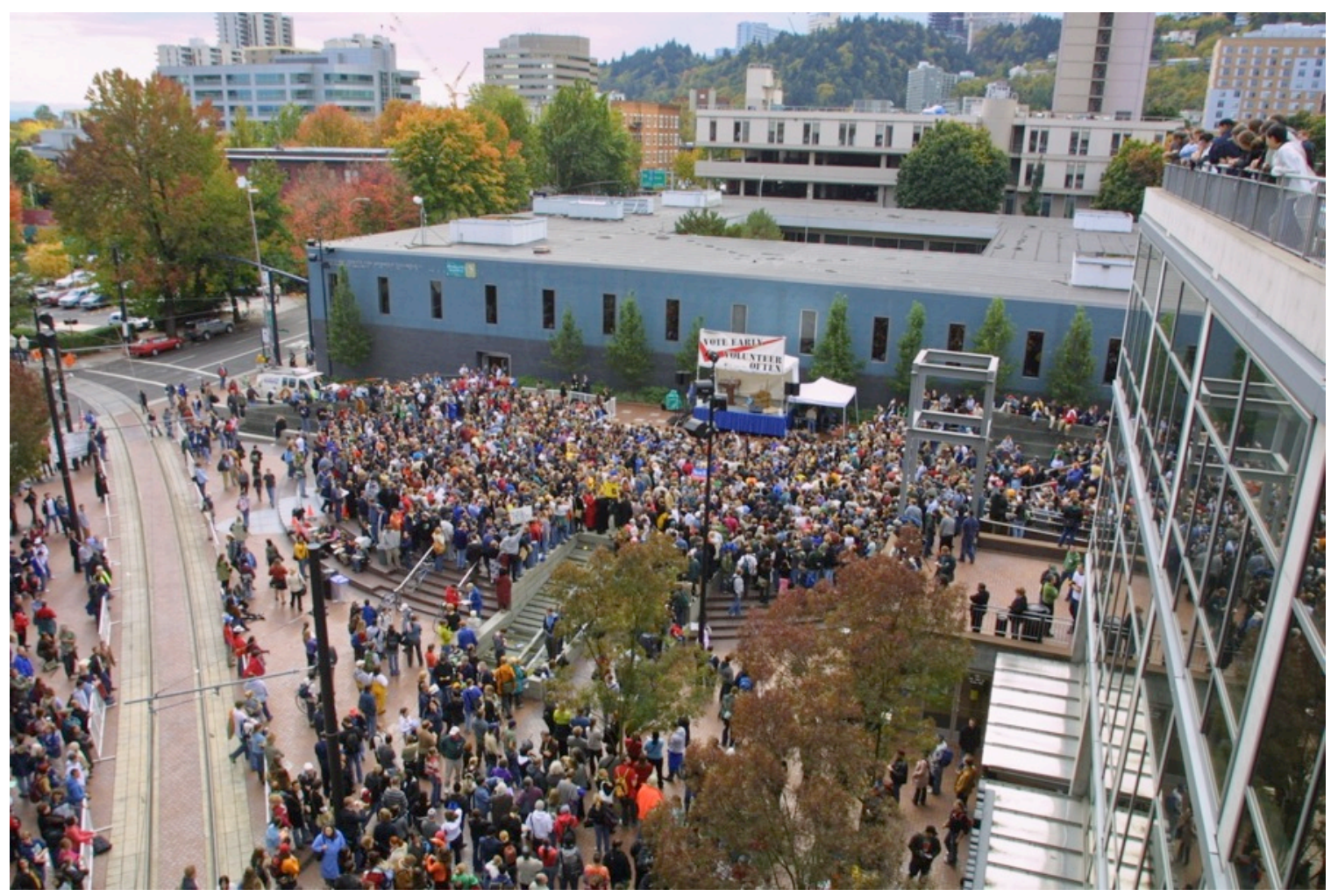

Figure 20: A large event in Phase 2 of the Urban Center Plaza, after streetcar came through, and before the storm water retrofit, light rail, and Recreation Building were constructed (image by Doug Macy, used with permission)

Phase Three: Montgomery Green Street. In the third phase, the plaza was

altered to include the green elements present today. In 2009, the architecture firm Nevue Ngan created a master plan for the SW Montgomery Green Street Concept Plan, a plan that would create large drainage swales to capture storm runoff and alleviate the sewer system (Nevue Ngan, 2012). Originally, the project did not impact the Urban Plaza. However, there was a desire to continue the plan consistently through SW Montgomery by the university, and a plan intended to minimally impact the original design was created according to Nevue Ngan (2012). The plan for the proposed Oregon Sustainability Center, on the block immediately to 
the east of the Rec Center, was also underway at this time, reinforcing a desire to make a "green" statement with the implementation of the green street plan.

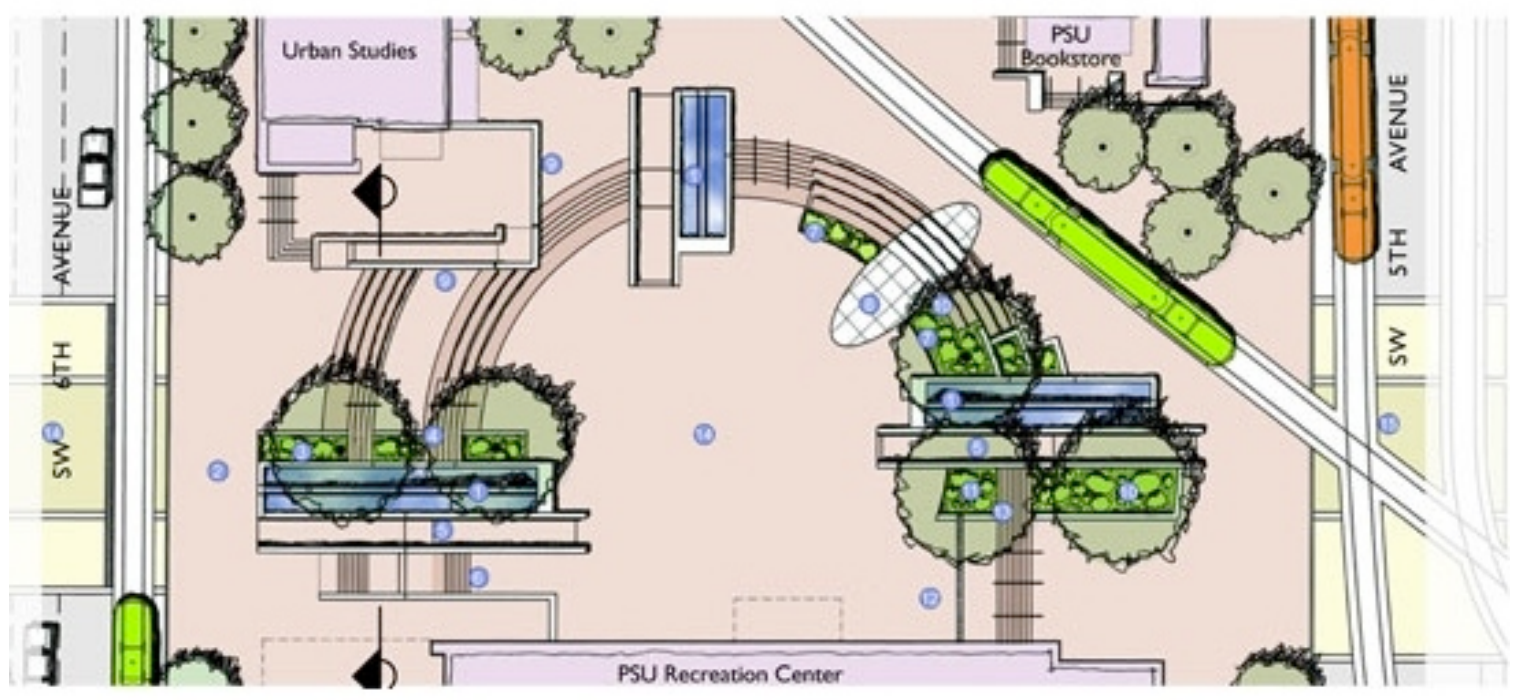

Figure 21: Plan for storm water retrofit by Nevue Ngan, before the light rail, but taking it into account ("Urban Center Plaza Stormwater Retrofit | Nevue Ngan Associates," 2011)

Alterations included sealed containers for drainage and evaporation of runoff from the higher SW $6^{\text {th }}$ Street and the grey space in the upper terrace (see Figure 22). Aspen trees were inserted in the containers (with moderate success) and a "living wall" of succulents was added to a wall on the eastern fountain. Another area of green space was planned to be near the upper seating area, though the complications regarding the art installation (the white oval on the terraced seats) prevented this from happening (see Figure 21 for original plan). This phase also included the completion of the Recreation Center building in 2010. One alteration to the plaza was the removal of the eastern steps set diagonally towards what is now the last stop for the light rail lines heading south. 


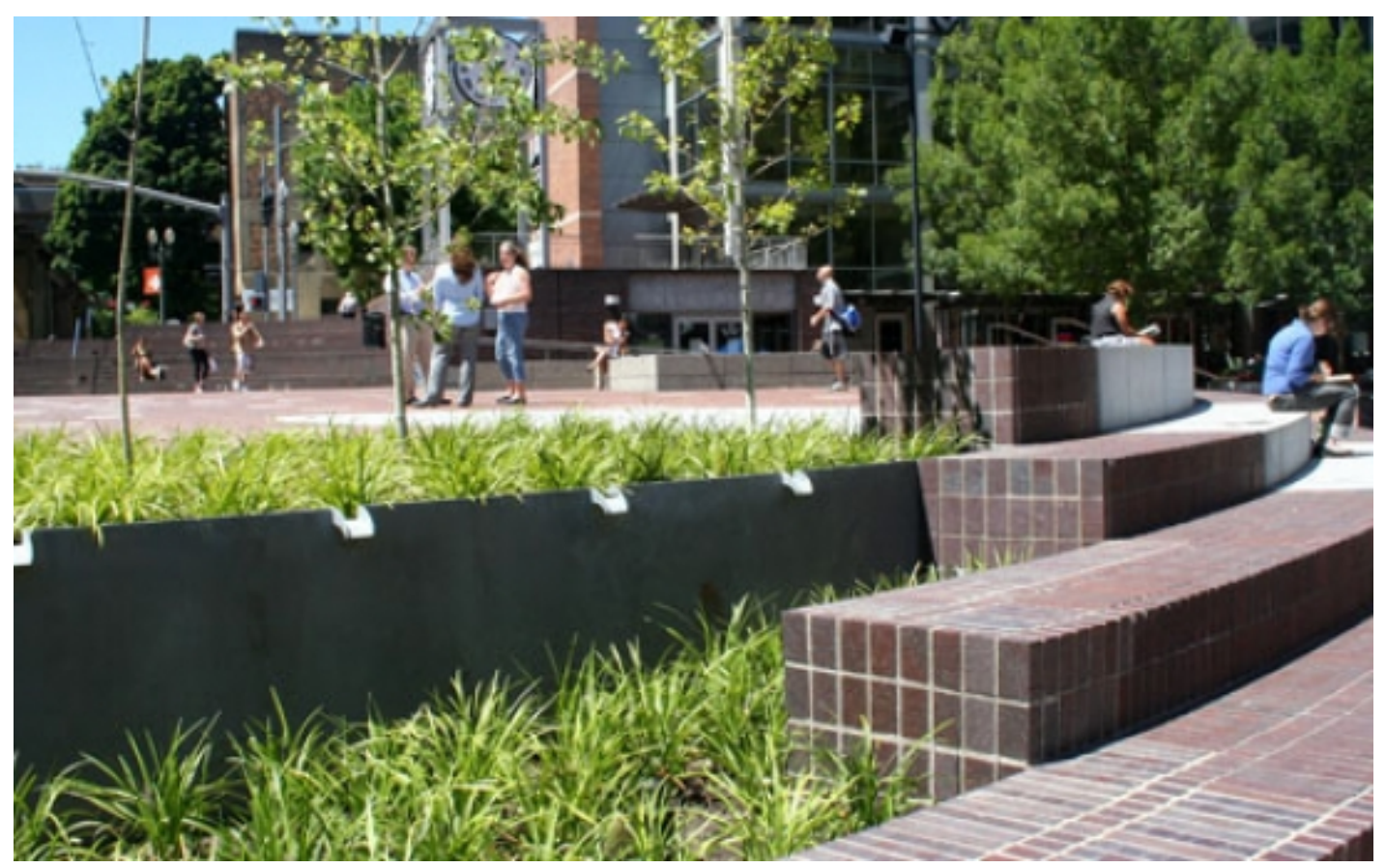

Figure 22: Stormwater retrofit by Nevue Ngan where east steps used to be, part of Phase 3 ("Urban Center Plaza Stormwater Retrofit | Nevue Ngan Associates," 2011)

Phase Four: Light Rail on SW $5^{\text {th }}$ and SW $6^{\text {th }}$. The fourth phase is similar to the present-day design, but with the addition of light rail lines flanking the plaza (see Figure 23).

Phase Five: Reorganized Street Furniture. The addition of a fifth phase is a new development implemented during the time of observations. Due to the increased bicycle commuting by students and faculty of the university, a second row of bicycle racks were added along the Urban Center, very near to the large granite art installation, and the benches in that area were rearranged (see Figure 26). While the observations did not include travel around this part of the plaza, this corner has now become almost completely blocked off by the racks and benches, but does accommodate more bicycle parking. Other bicycle racks were added in the uppermost areas of the plaza as well. 


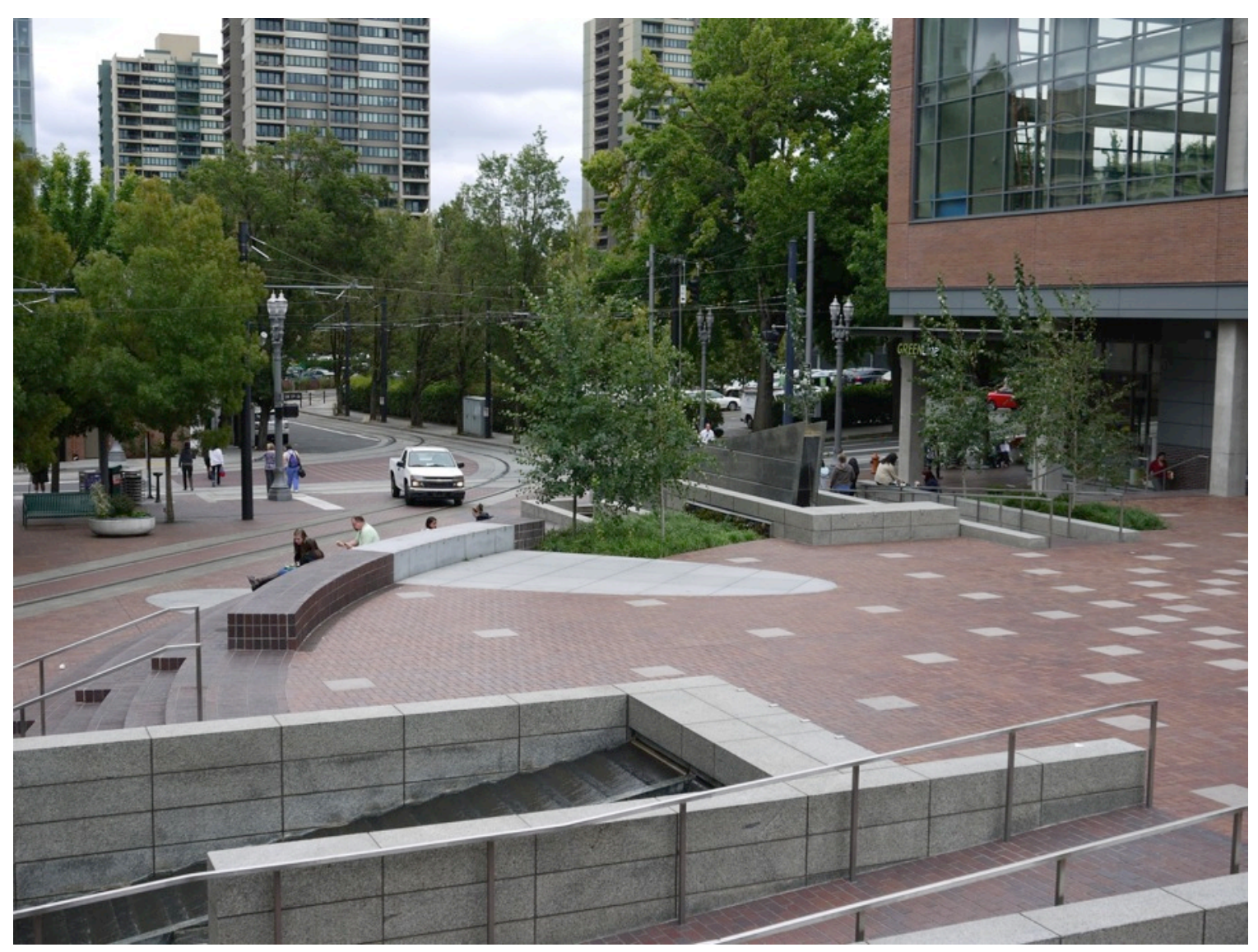

Figure 23: Phase 4 of the upper area of the Urban Center Plaza (photo by author, 2011)

The Urban Center Plaza today stands as a completed and well-used hub of student and community activity. Figure 24 shows a detailed map created of the plaza, features within it, and surrounding buildings and businesses. The Recreation Center building now has an entrance on the upper terrace of the plaza and acts as a major draw to this section of the university campus and the plaza. The northern corridor along the streetcar tracks has a stop heading north and hosts a coffee shop, pizza place, a local Bento counter, and now an ice cream store where the Tri-Met Information office used to be. These businesses have movable tables and chairs near the existing benches and trees that are well used in nice weather (see Figure 25). A bus stop is also nearby on the northwestern corner. 


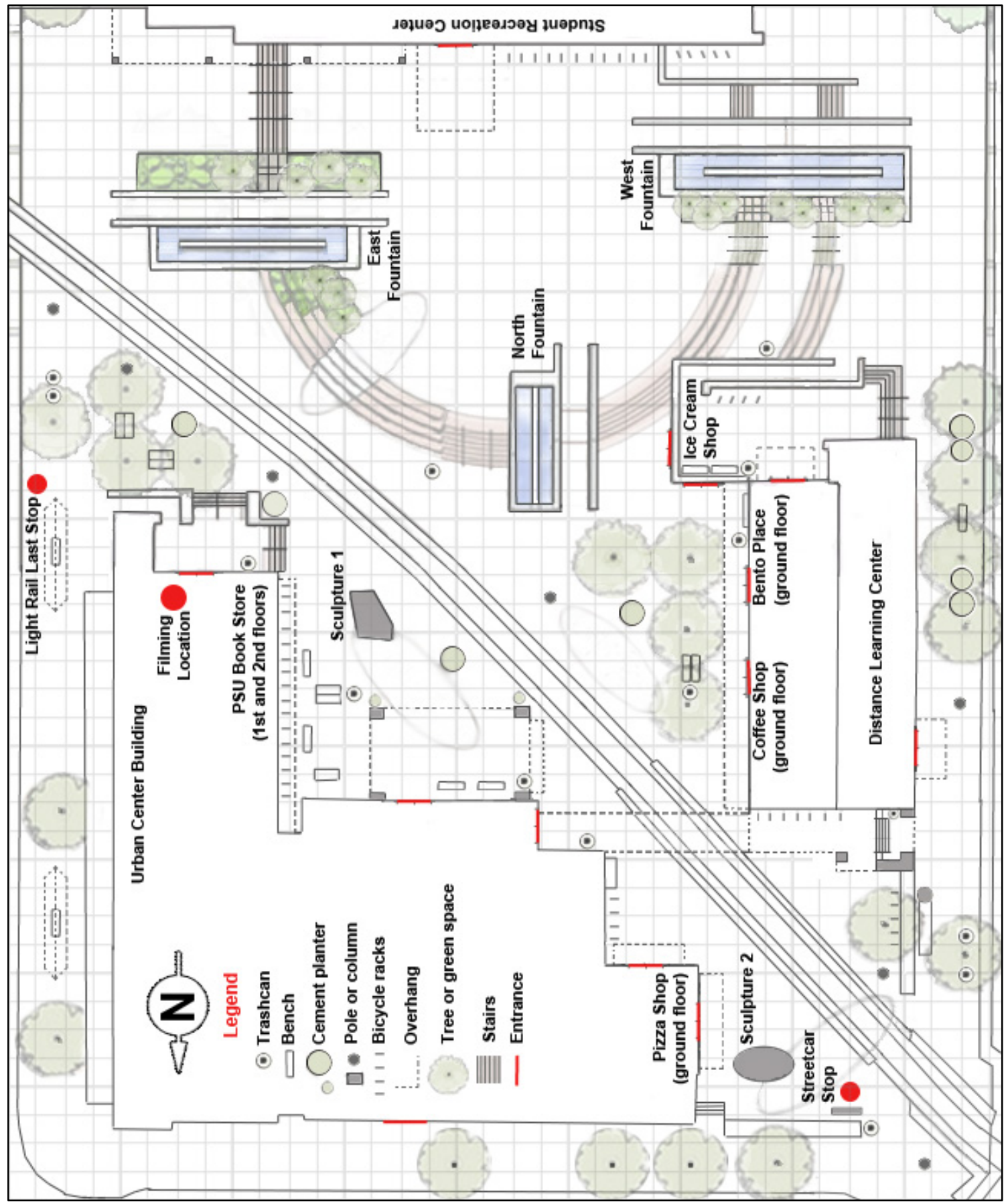

Figure 24: Map of Urban Center Plaza 


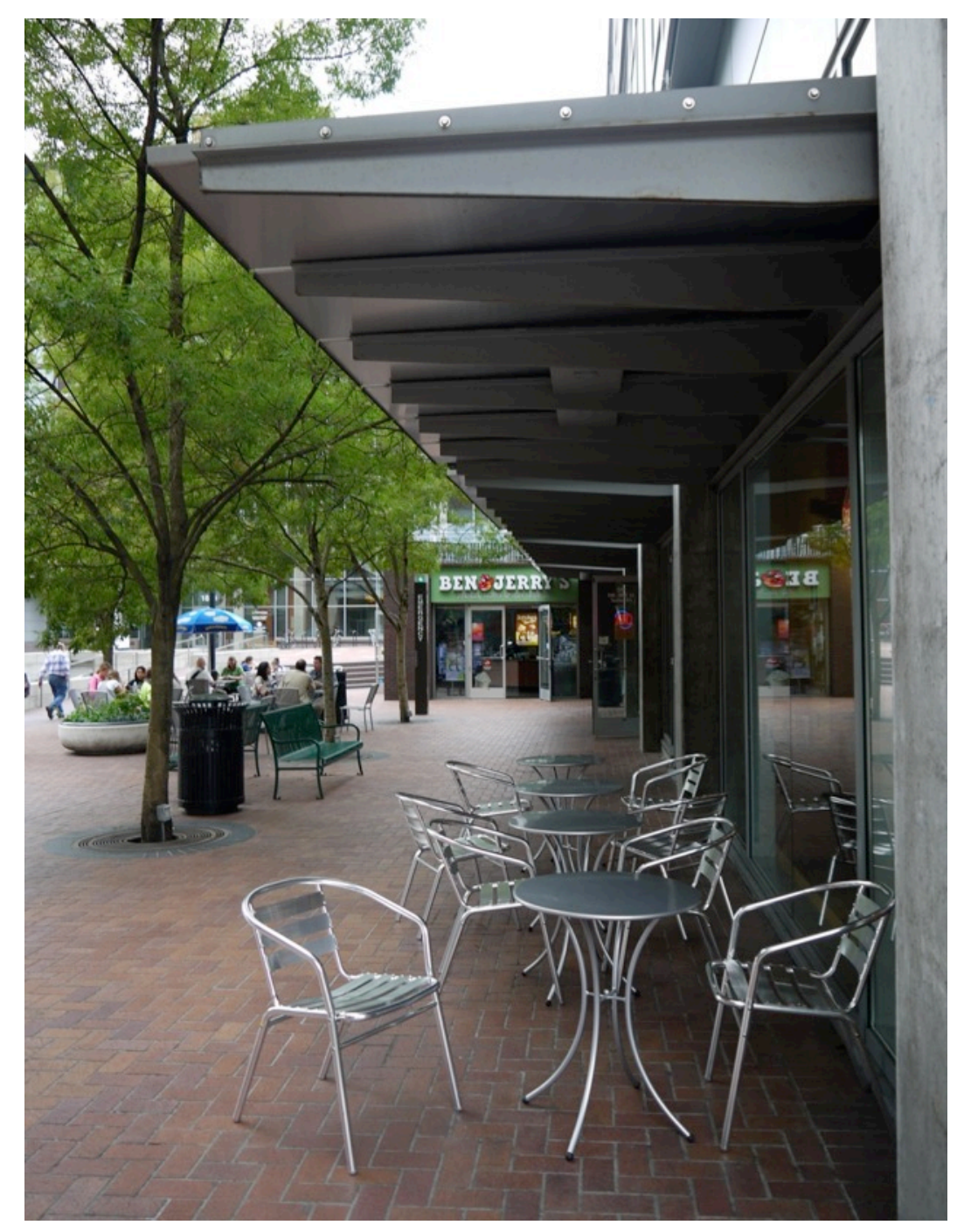

Figure 25: View from the northwest of lower plaza and cafe seating near restaurants (photo by author, 2011)

The eastern edge of the plaza has an entrance to the Portland State bookstore sunken somewhat, another nook with benches and trees, a planter, and numerous bike racks by the entrance to the Urban Center Building (see Figure 26). One of two large granite sculptures is also located here. Previously, only one row of bicycle racks lined the side of the building, but a second was added and the space was rearranged during the observations in 2011. 


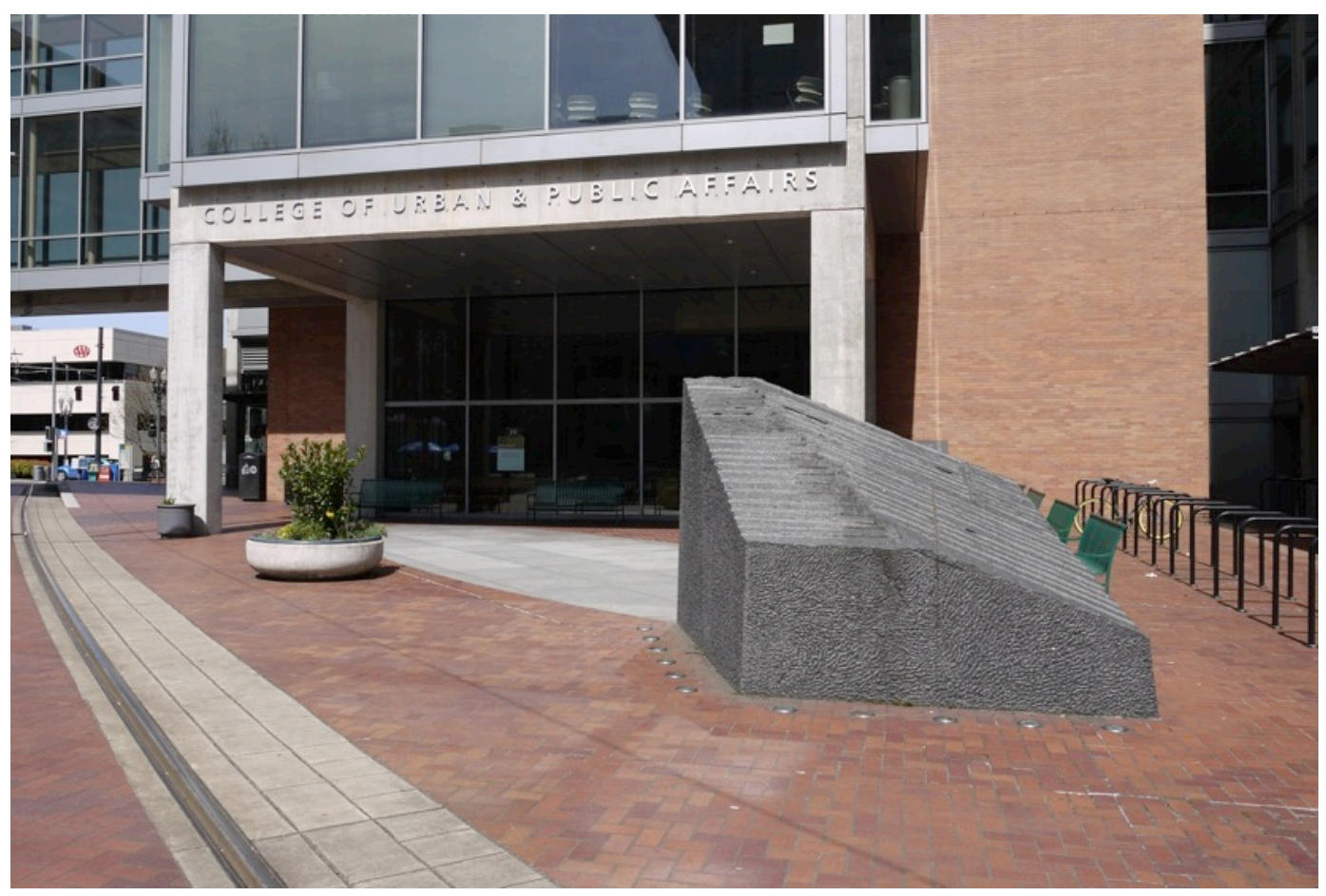

Figure 26: Northeastern corner near entrance to Urban Center building (left) and Portland State bookstore (right, beyond image) (photo by author, 2012)

On the southeastern corner, several businesses line the sidewalk side of the Recreation Center building with a small grocer on the corner of the plaza. A cover along the edge of the building allows for sheltered travel along the edge of the plaza or to the entrance of the building on the south edge if desired. Across the way, the southwestern corner sits at the highest grade with another entrance to the Recreation Center, a patio overlooking the plaza with bike racks, another set of tiered seating leading into the plaza, and another high patio with an entrance to the Distance Learning Center - part of the duo of Urban Center buildings (see Figure 27). 


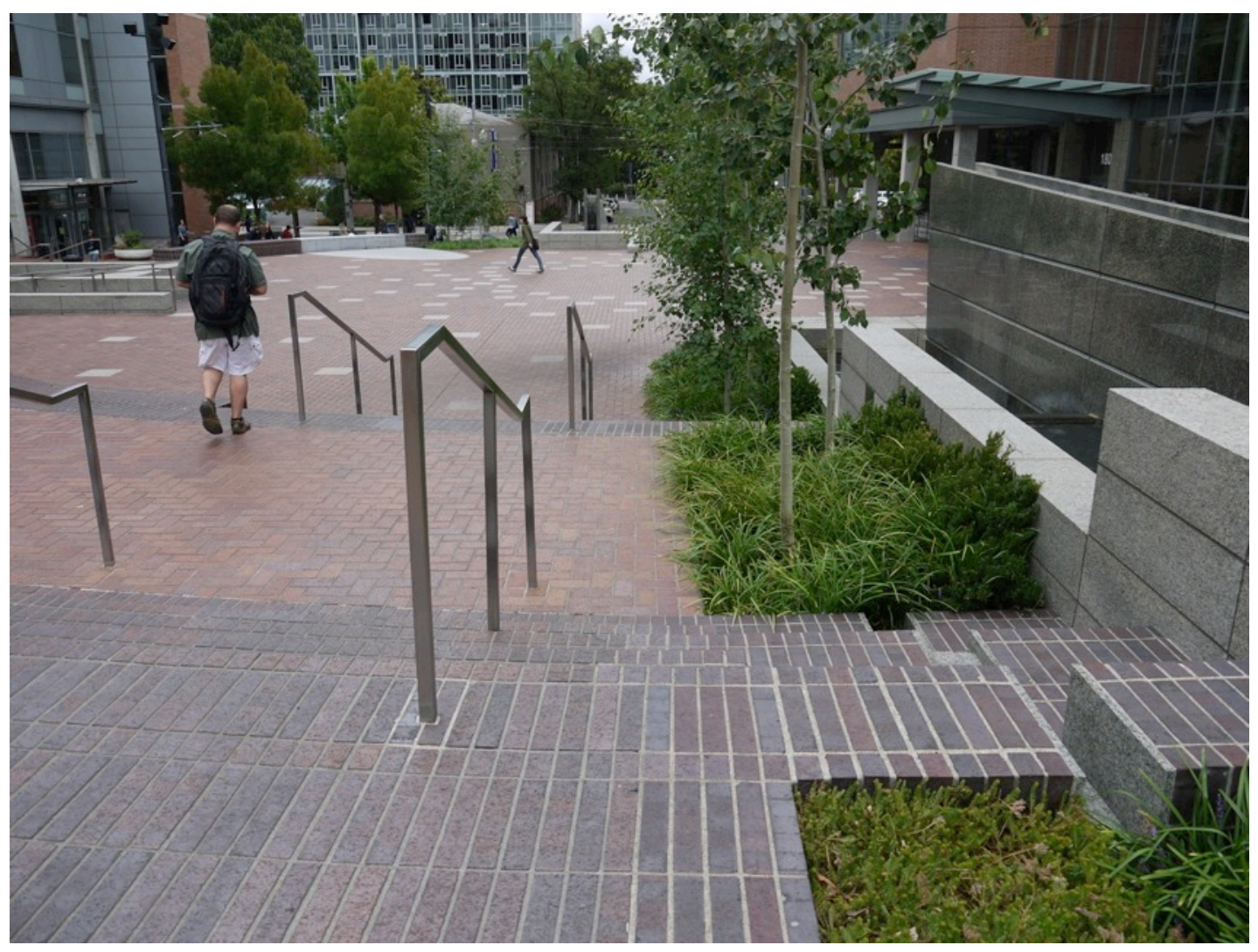

Figure 27: View of plaza looking east from top level of street, ramp and more stairs to the right, arcaded southeast corner in the distance (photo by author, 2011)

The upper terrace of the main plaza acts as the gradual transition space from the large grade change (see Figure 28). If walking in a straight line, there are technically eleven different ways of entering the plaza from above or below through a combination of ramps, small steps, and the seating areas which some people use like large steps (see Figure 31). Three fountains emphasize the grade change on the three non-bordered sides of the plaza, surrounded by a low wall which also doubles as a seating area. These are easily accessible by individuals who wish to interact with the water. Three ramps run along the fountains for handicapped access into the space and also double nicely as bicycle ramps. Alongside the eastern and western 
fountains are also the drainage additions to the plaza. Some seating was retained between sections of planters near the fountains as well (see Figure 27).

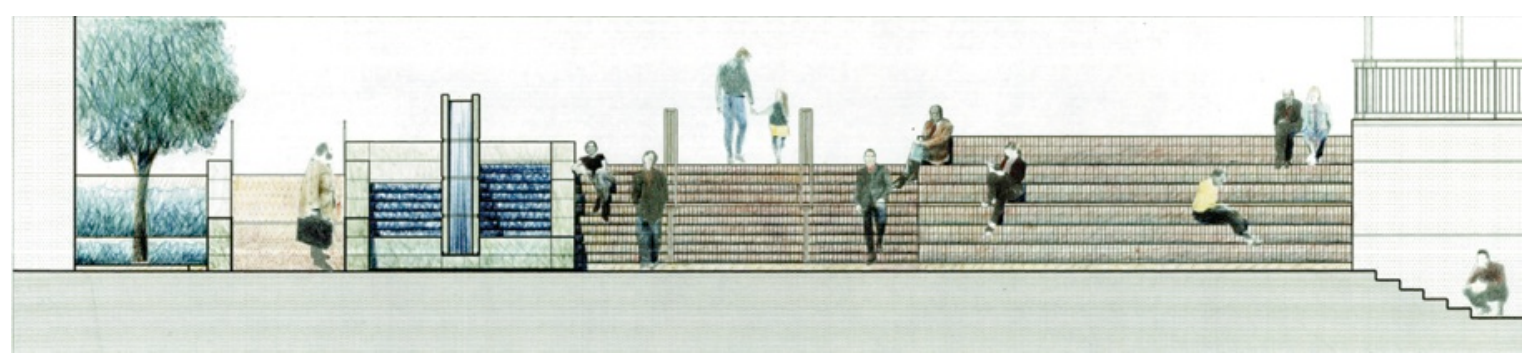

Figure 28: Illustration showing the grade changes of the plaza levels, looking from the east (image by Doug Macy, used with permission)

Several different types of steps provide further access into the plaza (see Figure 29 and Table 7). The first type is on all sides and is composed of smaller steps with freestanding railings in the middle. A set of this type of step was taken out for one of the drainage planters on the east side. The second type feels like a more gradual approach to ascent/descent, as found on the west and north sides. These have no railings and the northern set actually curves to the west, ending in a corner of the Distance Learning Center building where the ice cream store is now. Both of these are comfortable dimensions as per Whyte's suggestion (Whyte, 1990). The third type of steps is more intended for seating. One prominent set of these faces the north and a set of two bordering a platform looks east on the western side. While larger than standard steps, they are definitely used as yet another stairway into and out of the plaza, possibly because of their relatively lower height (12" compared to 16 " for instance). 
Table 7: Types of steps found in the Urban Center Plaza

\begin{tabular}{|c|c|c|}
\hline Step Type & Measurements & Location \\
\hline $\begin{array}{l}\text { 1. Smaller steps } \\
\text { (with railing) }\end{array}$ & $6 " \times 16^{\prime \prime}$ & $\begin{array}{l}\text { East, west, and north sides } \\
\text { of upper plaza }\end{array}$ \\
\hline $\begin{array}{l}\text { 2. Gradual steps } \\
\text { (without railing) }\end{array}$ & $6 " \times 16 "$ & $\begin{array}{l}\text { Northwest side of upper } \\
\text { plaza }\end{array}$ \\
\hline 3. Seat steps & 12 1/4" x 32" & North and west sides \\
\hline
\end{tabular}

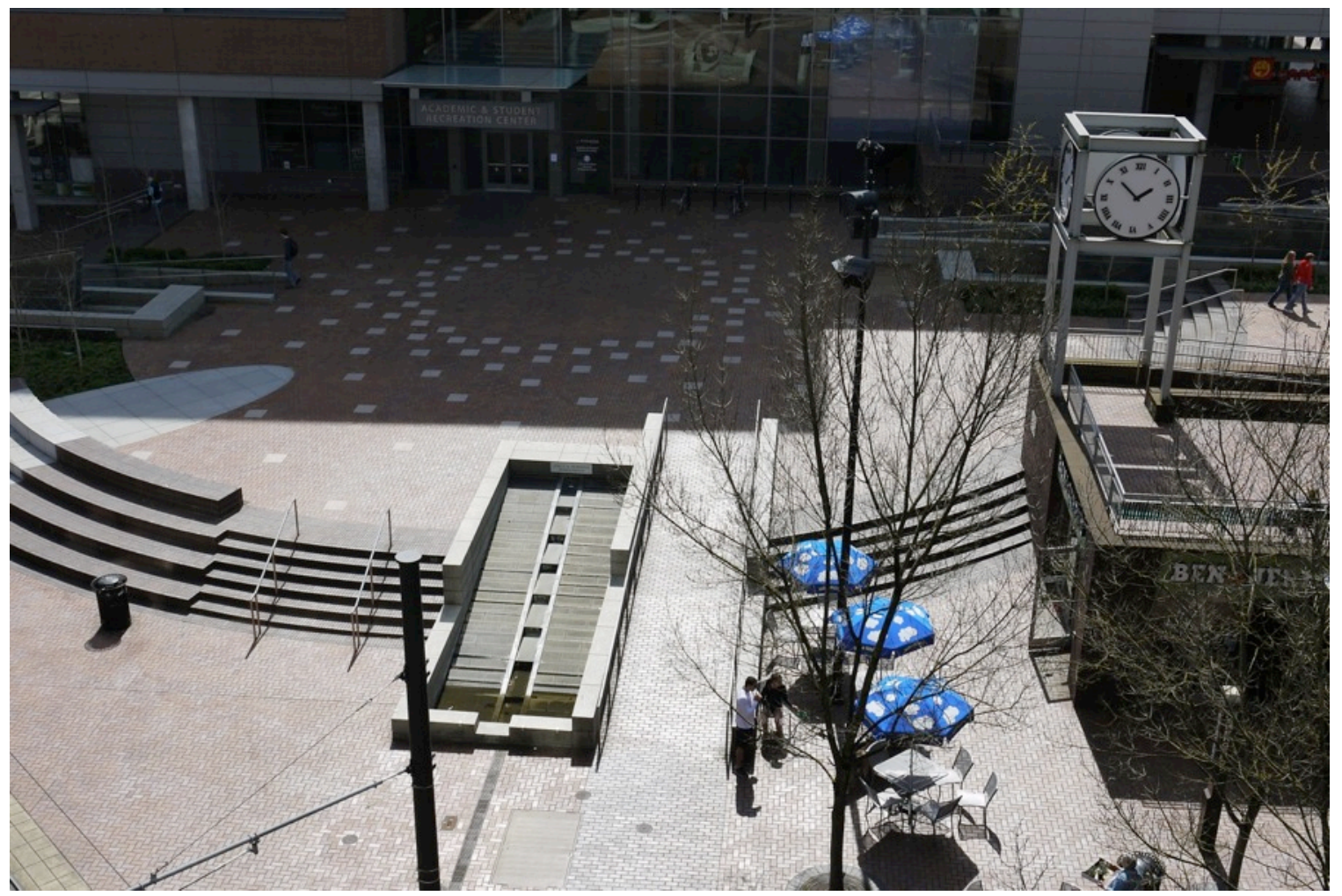

Figure 29: Image of plaza showing three types of stairs (left to right: seat steps, smaller steps, gradual steps) (photo by author, 2012)

\section{Video Observations}

During two weeks between September $18^{\text {th }}$ to $24^{\text {th }}$ and September $25^{\text {th }}$ to October $1^{\text {st }}, 2011$, randomized video observations were conducted of the Urban Center Plaza. Five days between Monday and Saturday each week were chosen at random and five of ten hours between 9:00 AM and 7:00 PM were observed at random as well (see Appendix A for observation schedules). Using a Panasonic DMC-G2 camera, continuous recordings (as opposed to time-lapse footage) were 
taken from the perspective of the south end of the third floor hallway within the Urban Studies and Planning offices in the Urban Center building (See Figure 30). Activity was observed during the week before fall term classes began at Portland State University (September 18-24) and the week that classes start (September 25 - October 1). This was also conducted during a good time of the year for Portland. Saturdays were included in order to determine whether there was a difference between usage patterns of behavior during a non-work or class day. Randomization was determined by using online randomization services. Subjects were considered anonymous due to the distance of the camera and their consent was therefore waived. Notices were placed in the lobby of the nearby building notifying people that the plaza would be recorded during that day, to be safe (see Appendix B).

The goal in these observations was to address how people navigate and interact with the built environment of the plaza, and what, if anything has changed in comparison with previous research. Part of the original observation research design was to conduct additional observations in order to gain a better perspective of the plaza in various seasons. However, it was quickly realized through video and direct observation that sitting and pausing patterns within the space during the winter would not occur frequently enough to measure due to rain and cold weather.

Video footage was organized according to the actual time recordings were conducted, and the assigned time according to the hours randomly chosen. Appendix C lists all observed dates, the video file number, actual time recorded in 
real time, and the assigned time as per the randomization schedule. Video footage was compiled into single video files for each day and rendered for ease of viewing. Analysis was conducted by hand while watching the footage in real time. A detailed map of the space was created by using satellite images and original plans for the plaza, modified to match the current layout as per the observations (see Figure 24). In this map, the Urban Center building (left) and Student Recreation Center (right edge) are shown in white. Dotted lines indicate an overhang and green areas indicate green space, planters, or trees. Circles and rectangles represent the position of trashcans and benches. Objects in grey are solid structures that cannot be normally stood on top of (poles, columns, sculptures, etc.).

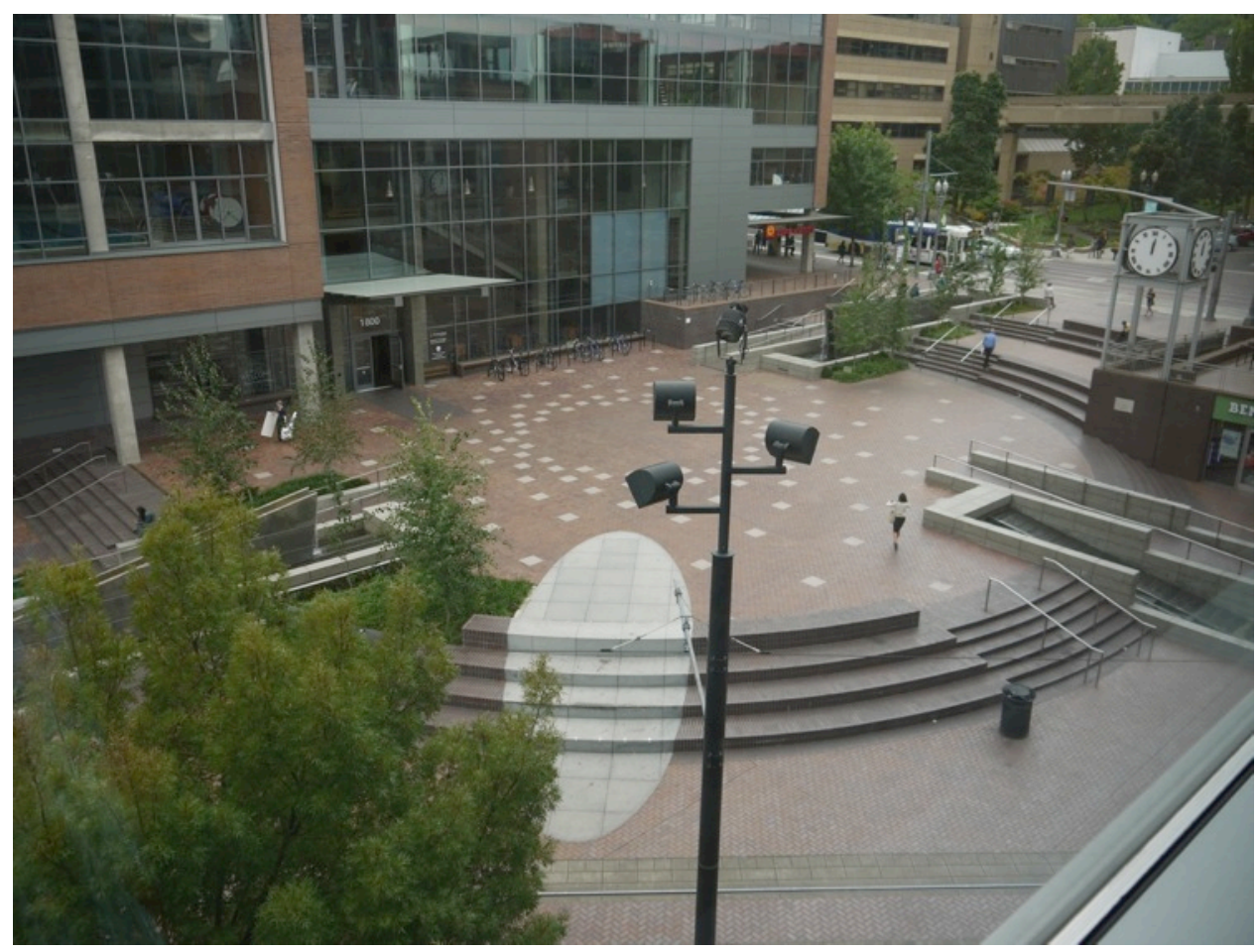

Figure 30: The perspective of the camera's position looking northwest (photo by author, 2011)

Boundaries for determining the space analyzed were established according to the camera's perspective as can be seen in Figure 30. Individuals were counted 
entering into the plaza including those walking on or across the streetcar tracks to the north (closest to the camera), the edge of view to the east (to the left, including all those walking up the south stairs and walking past the large tree in view), those walking down into the plaza from the west via the several sets of stairs or the ramp, and those in view walking into the plaza from the north (ending at the northern end of the water feature and at the doors of the ice cream store). Figure 31 shows the 11 possible entrance points into the plaza. Individuals on the street along the western edge or on the elevated areas of that region were not counted. Individuals walking along the northern edge of the streetcar tracks were noted for their route but were not counted for consistency's sake due to the lack of complete visibility in that area, unless they paused (which was frequently and notably on the streetcar tracks themselves). 


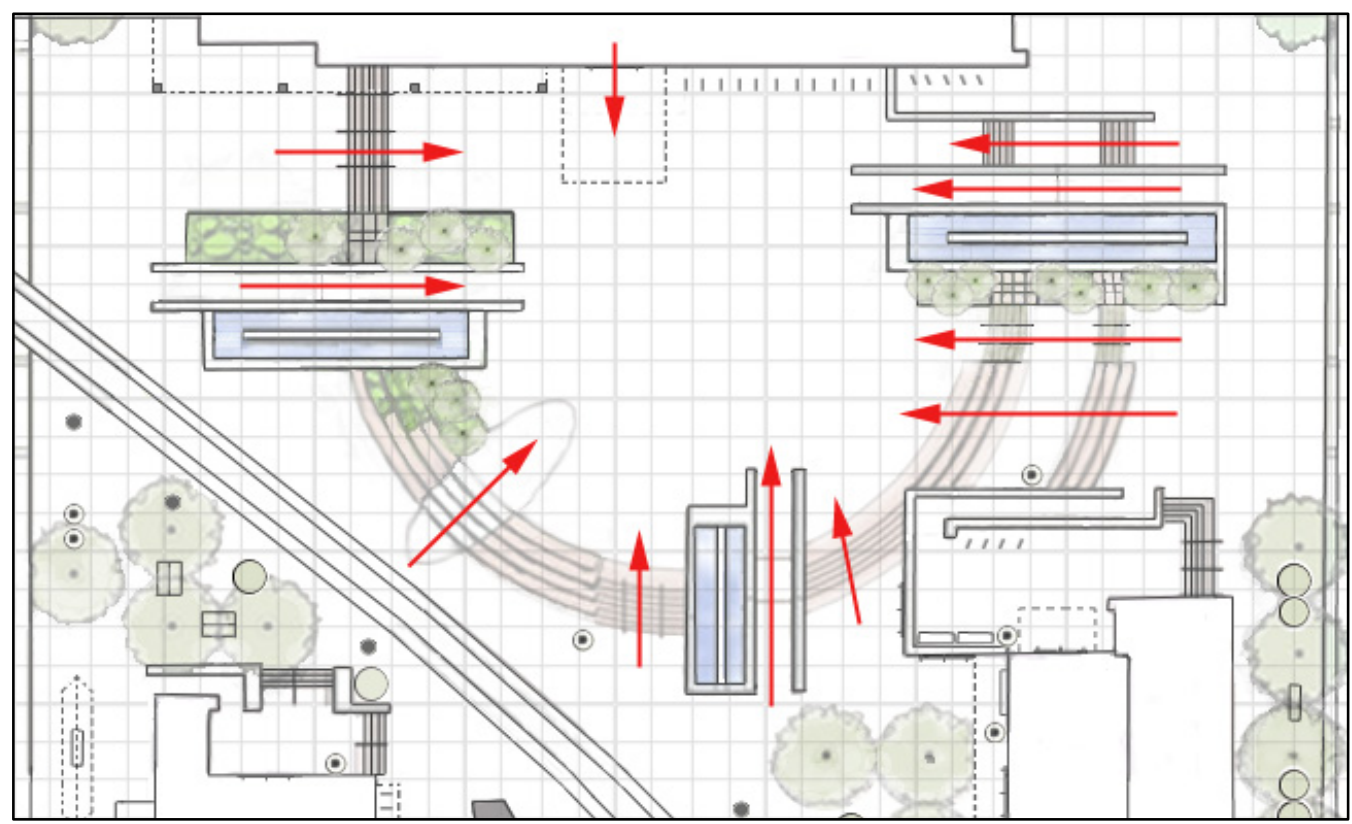

Figure 31: Entrance points into the Urban Center Plaza

Individuals in the plaza were divided into several categories in order to keep track of different elements and types of use:

1. Those passing through the plaza - completely walking across or entering and then exiting again.

2. Those passing alongside the plaza - to the east or south.

3. Those pausing in place - defined as those standing in place for more than five seconds or individuals pacing slowly (i.e. while talking on the phone).

4. Those sitting in the plaza - within the previously stated boundaries only.

Those passing through, pausing, or sitting, were all considered "walkers" and counted as they entered the plaza at each entry point. Individuals walking with bicycles or riding bicycles were counted as "bicycles" in order to see the flow of bicycles through the space and how often they were in the plaza. People in wheelchairs, strollers, and those running (for obvious exercise purposes), were also treated similarly and counted separately. Seated and paused individuals were labeled on the map, as were travel routes. Other general events, unusual or notable 
behavior, shade cover, and any other categories aside from the previous list were also recorded in that hour's observations.

\section{Participant Observations}

This entire project was admittedly initiated by the author's interaction with the plaza through the graduate program's location in the Urban Center building. Through interaction with the space, casual observations, and conversations with others, it quickly became clear that many people had opinions of the Urban Center Plaza because of its prominence and the politics surrounding its construction and alterations. Ask anyone who frequents the plaza or overlooks it in an office from above and they will surely have something to say about its design. The most commonly cited comment concerns the number of people laboriously walking up the "steps" intended for sitting on while travelling across the plaza. Every so often an individual will miscalculate the height of the top-most step and take a tumble frequently followed by a collective gasp by the onlookers.

In-person observations were primarily during the warmer months when lunch-goers frequently find a spot to eat, groups gather to chat, and an occasional game of Frisbee is held. Observations on travel and general behavior through the plaza were done continuously, including during the rainy winter months, between August 19, 2011 and March 10, 2012 (see Table 8 for climate information). The author's frequent contact with the plaza in coordination with deliberate observations allowed for data to be gathered several times per week during this time. These more casual observations provided supplemental qualitative 
information for the randomized video recordings. Some observations were also conducted from a slight distance, either inside the building or from an adjacent balcony to observe behavior from above.

Table 8: Climate data for Portland, Oregon (Threadex Station) 1981-2010 ("National Weather Service NWS Portland," 2012). Months observed highlighted in blue.

\begin{tabular}{|l|l|l|l|l|l|l|l|l|l|l|l|l|}
\hline Month & Jan & Feb & Mar & Apr & May & Jun & Jul & Aug & Sep & Oct & Nov & Dec \\
\hline $\begin{array}{l}\text { Average } \\
\text { High } \\
\left({ }^{\circ} \mathbf{C} \text { ) }\right.\end{array}$ & $\begin{array}{l}47.0 \\
(8.3)\end{array}$ & $\begin{array}{l}51.3 \\
(10.7)\end{array}$ & $\begin{array}{l}56.6 \\
(13.7)\end{array}$ & $\begin{array}{l}61.4 \\
(16.3)\end{array}$ & $\begin{array}{l}67.9 \\
(19.9)\end{array}$ & $\begin{array}{l}73.5 \\
(23.1)\end{array}$ & $\begin{array}{l}80.5 \\
(26.9)\end{array}$ & $\begin{array}{l}81.1 \\
(27.3)\end{array}$ & $\begin{array}{l}75.8 \\
(24.3)\end{array}$ & $\begin{array}{l}63.8 \\
(17.7)\end{array}$ & $\begin{array}{l}52.7 \\
(11.5)\end{array}$ & $\begin{array}{l}45.5 \\
(7.5)\end{array}$ \\
\hline $\begin{array}{l}\text { Average } \\
\text { Low }{ }^{\circ} \mathbf{F} \\
\left({ }^{\circ} \mathbf{C}\right)\end{array}$ & $\begin{array}{l}35.8 \\
(2.1)\end{array}$ & $\begin{array}{l}36.3 \\
(2.4)\end{array}$ & $\begin{array}{l}39.7 \\
(4.3)\end{array}$ & $\begin{array}{l}43.2 \\
(6.2)\end{array}$ & $\begin{array}{l}48.7 \\
(9.3)\end{array}$ & $\begin{array}{l}53.7 \\
(12.1)\end{array}$ & $\begin{array}{l}57.9 \\
(14.4)\end{array}$ & $\begin{array}{l}58.0 \\
(14.4)\end{array}$ & $\begin{array}{l}53.2 \\
(11.8)\end{array}$ & $\begin{array}{l}46.1 \\
(7.8)\end{array}$ & $\begin{array}{l}40.5 \\
(4.7)\end{array}$ & 35.2 \\
\hline $\begin{array}{l}\text { Precip- } \\
\text { itation } \\
\text { Inches } \\
(\mathbf{m m})\end{array}$ & 4.88 & 3.66 & 3.68 & 2.73 & 2.47 & 1.70 & 0.64 & 0.66 & 1.47 & 3.00 & 5.64 & 5.49 \\
$(124)$ & $(93)$ & $(93.5)$ & $(69.3)$ & $(62.7)$ & $(43.2)$ & $(16.3)$ & $(16.8)$ & $(37.3)$ & $(76.2)$ & $(143.3)$ & $(139.4)$ \\
\hline $\begin{array}{l}\text { Snowfall } \\
\text { Inches } \\
(\mathbf{c m})\end{array}$ & 0.3 & 1.2 & 0.1 & 0.0 & 0.0 & 0.0 & 0.0 & 0.0 & 0.0 & 0.0 & 0.2 & 0.7 \\
$(0)$ & $(3)$ & $(0.3)$ & $(0)$ & $(0)$ & $(0)$ & $(0)$ & $(0)$ & $(0)$ & $(0)$ & $(0.5)$ & $(1.8)$ \\
\hline
\end{tabular}

As part of the participant observations, phenomenological experiments were conducted in the plaza in order to better understand what the experience is like for those being observed. To do this, the author deliberately positioned herself in various seating areas to experience the different perspectives and travelled across the plaza from various directions to assess her own travel behavior. By observing the most popular and least popular seating areas, she then sat there myself and took note of the perspective from that angle - how people sat nearby, how they pass by, what the range of vision was, and what the environment felt like regarding light or shade. Sensations regarding perspective and comfort of the different areas were taken into consideration when analyzing the video recordings of the plaza such that it was understood how people felt sitting in certain areas or taking a certain path. These phenomenological observations were not added to the behavior and travel maps, however. 


\section{In-Depth Interviews}

To more fully understand the history and process of development, in-depth interviews were conducted with the individuals most involved in the various stages of the plaza. This includes the Dean at the time, Dean Emeritus Nohad A. Toulan, Doug Macy of the Walker Macy architecture firm, a member of Nevue Ngan Associates, and Rudy Barton who was on the City Design Commission in charge of reviewing the city's projects at the time (see Appendix D for list of interviews).

Participants were asked to explain how they were involved in the creation or alteration of the plaza, if they are still involved, how they feel about the result, and how they would change it now (see Appendix E for example questions). Interview questions were altered during the course of each interview depending on the context and no audio or visual recording was done. All participants were kept anonymous unless explicitly stated and signed as acceptable in the consent form (see Appendix F). Information gained through the interviews was used to construct some of the historical and phase components of the History and Overview of the Plaza section in Chapter 3 and influenced the conclusions as well.

\section{Alterations to Original Research Design}

A component of the original research design was altered during the course of this project. Initially intercept surveys were going to be conducted on users of the plaza in the plaza itself to quickly (in five minutes or less) gather information regarding how people used the plaza and what they thought about the space. The hypothesis was that users of the space might have insight regarding how the space 
could be improved upon or add material to complement the video and in-person observations. However, these surveys would most likely have not been enough to assess users' feelings on the plaza due to the convenience sample design.

It was realized a more realistic focus of this project would be to analyze what behavior was observed regarding staying and travel behavior and interaction with the built features in the plaza instead. By analyzing the space in comparison with other successful spaces, in accordance to the methodological review, it was possible to observe from a distance what is successful in this space simply by watching people without interference. Further, methods were mostly based on Whyte, Low, and Gehl's research of public space, which addressed the same sorts of questions that were to be answered, and does not include intercept surveys. And unlike Mehta's research, which did include surveys and interviews with those in proximity to the successful streets he studied, the goal was not necessarily to discover why it was successful or what people wanted in the space, but if it was successful and how people use the space in relation to the design features.

If more information was needed about this question in particular and there was more of an ability to do so, flyers would have had to be distributed in the neighborhood and to those using the plaza for a more in-depth digital survey in order to gather more relevant and detailed information (see Chapter 5 for more discussion). Because of this, one of the goals of the project originally planning to address this topic was removed from this thesis. 


\section{Chapter 4. Analysis and Results}

Data was analyzed according to the two types of data gathered: a systematic quantitative analysis and a qualitative assessment of the space. The systematic analysis was based on randomized video observations supplemented with in-person observations and the qualitative data was analyzed through a combination of inperson ethnographic observations and video recordings. Each of these were subsequently broken down into several behavioral categories including sitting, pausing, travel, standard and nonstandard activities, daily life, and constant characters.

Video recording data was analyzed by week due to the marked difference between the week before classes began (September 18 - 24, 2011) and when class began in the second week (September 25 - October 1, 2011). Total pedestrian counts from the video recordings are analyzed as a group per week, while seating and pausing behavior were parsed out for more detailed analysis afterwards. The counts were analyzed separately from the seating and pausing maps. Travel behavior across the plaza was mapped based on video and in-person observations but not quantitatively analyzed. Phenomenological data of travel and seating behavior was not included in the maps.

Video and in-person observations allow for an analysis of the daily life of the plaza based on overall trends. Also described are significant characters of the plaza, children's behavior, and a look at the weekday vs. weekend nature of the plaza. After this general overview, these results are compared more directly with the Capstone 
course's findings, potential conflict in the plaza is identified, and successful elements are discussed.

\section{Behavior in the Urban Center Plaza Pedestrian Counts Per Week}

Pedestrian counts show a marked increase in traffic during the second week of observations, as expected, when the fall term of classes began. Appendix G shows the complete records for the pedestrian counts during both weeks for the hours of randomized video observations. "Total" indicates total number of pedestrians including walkers, bicyclists, etc. Sit and pause events were counted separately for event analysis but also recorded as part of the walker category since those individuals were walkers before they sat down and/or paused. The "Other Items" category was intended to capture items or events that could potentially affect the data such as tents, cars, people on scooters, people on skateboards, people using walkers, and bike carts in particular. This last category was less common than the others, but assisted in assessing the space. For instance, the interaction between bicycles, people walking through the plaza, and people using walkers was unique due to the difference in speed. 


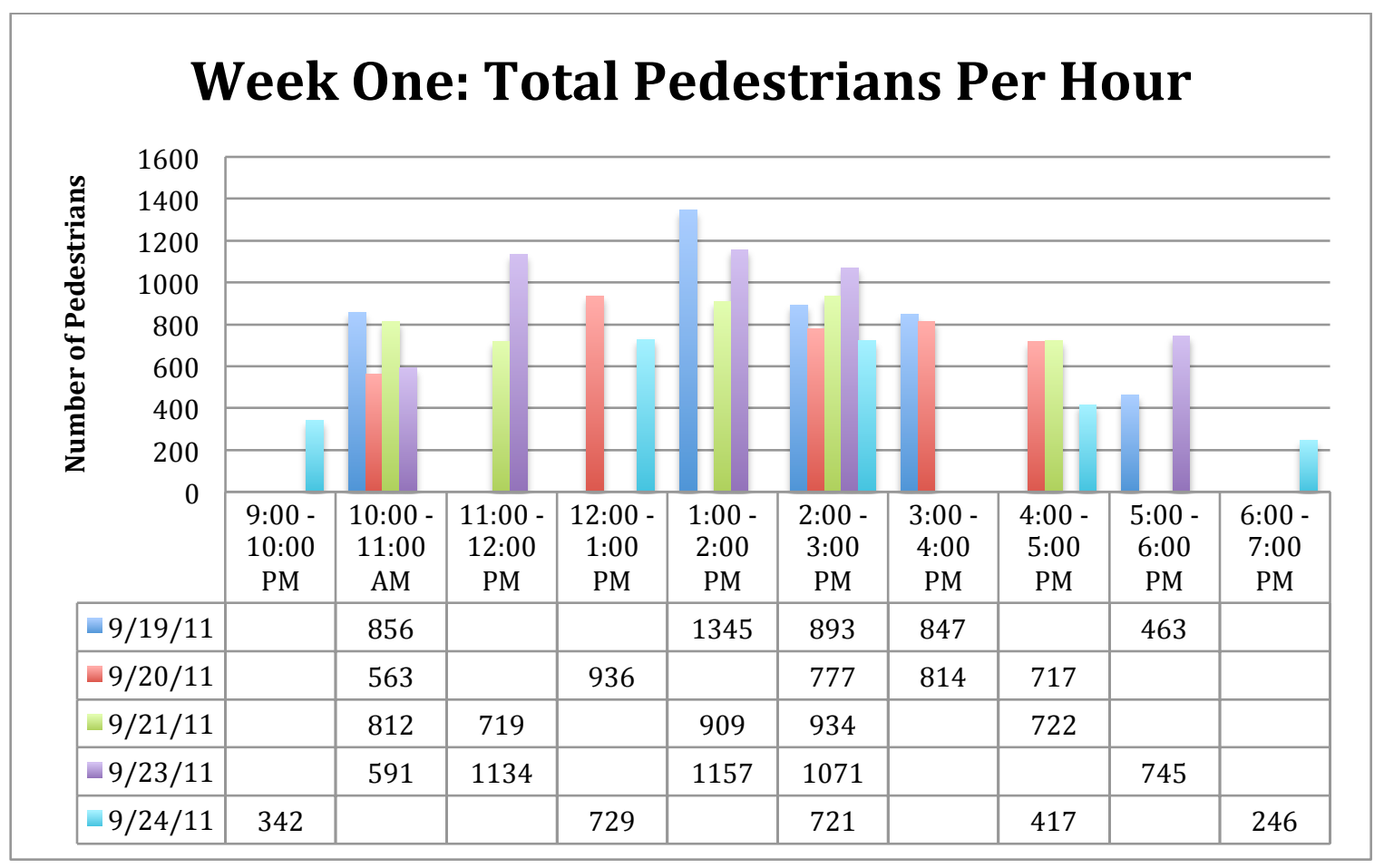

Figure 32: Total Pedestrian Counts for Week One

During the first week, the highest number of pedestrians counted was 1,345 between the hours of 1:00 PM and 2:00 PM on Tuesday, September 19, 2011 (see Figure 32). Saturday, September $24^{\text {th }}$ had the lowest count recorded dipping down all the way to only 246 from 6:00 PM to 7:00 PM. Temperature for this week averaged $76^{\circ} \mathrm{F}$ with a high of $83^{\circ} \mathrm{F}$ on Friday September $23^{\text {rd }}$ though it does not seem to have impacted attendance significantly either way. At a glance, the early morning and evening seem to have the lowest number of people in the plaza with the mid-day hours showing the most people. Looking at the average counts for week one we can see this normal distribution does seem to be the case (see Figure 33). It was surprising to see this trend so clearly, but something similar was expected based on the observations. It is difficult to say precisely how class times affect these counts due to the multitude of classes taking place at various times. However, the 
higher number of pedestrians in the plaza during the midday may be due to people taking a lunch break from the nearby buildings and campus.

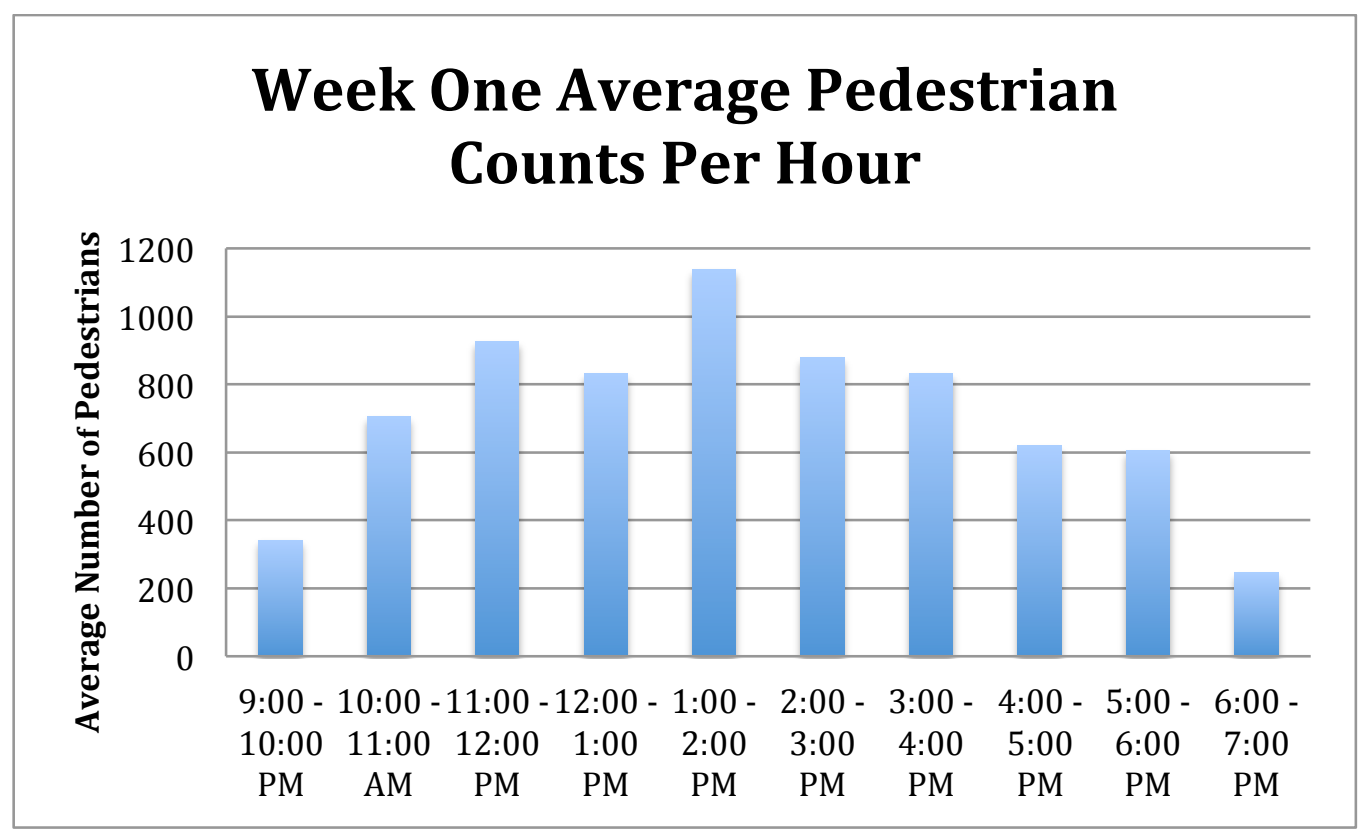

Figure 33: Average Pedestrian Counts Per Hour for Week One

The second week's results show a large increase in pedestrians counted in the plaza overall. While Saturday, September $31^{\text {st }}$ is as low as 322 people, the highest soars to 2,600 from 11:00 AM to $12: 00$ PM on Monday, September $26^{\text {th }}$ (see Figure 34). Average high temperature measured $71^{\circ} \mathrm{F}$ with a high of $82^{\circ} \mathrm{F}$ on Thursday September $29^{\text {th }}$ and the lowest high of $67^{\circ} \mathrm{F}$ on Saturday October $1^{\text {st }}$. Again, temperature does not seem to have a drastic effect given that Saturdays tend to be sparse to begin with. While not quite as strong as the first week's average counts, the hour between 1:00 PM and 2:00 PM is still the highest volume, and fewer people seem to be in the plaza in the early morning and evening hours (see Figure 35). Unfortunately, due to randomization, the hour of 4:00 PM to 5:00 PM was never 
counted in the second week. Suggestions for the improvement of this project due to this (and other items) are considered in a later section.

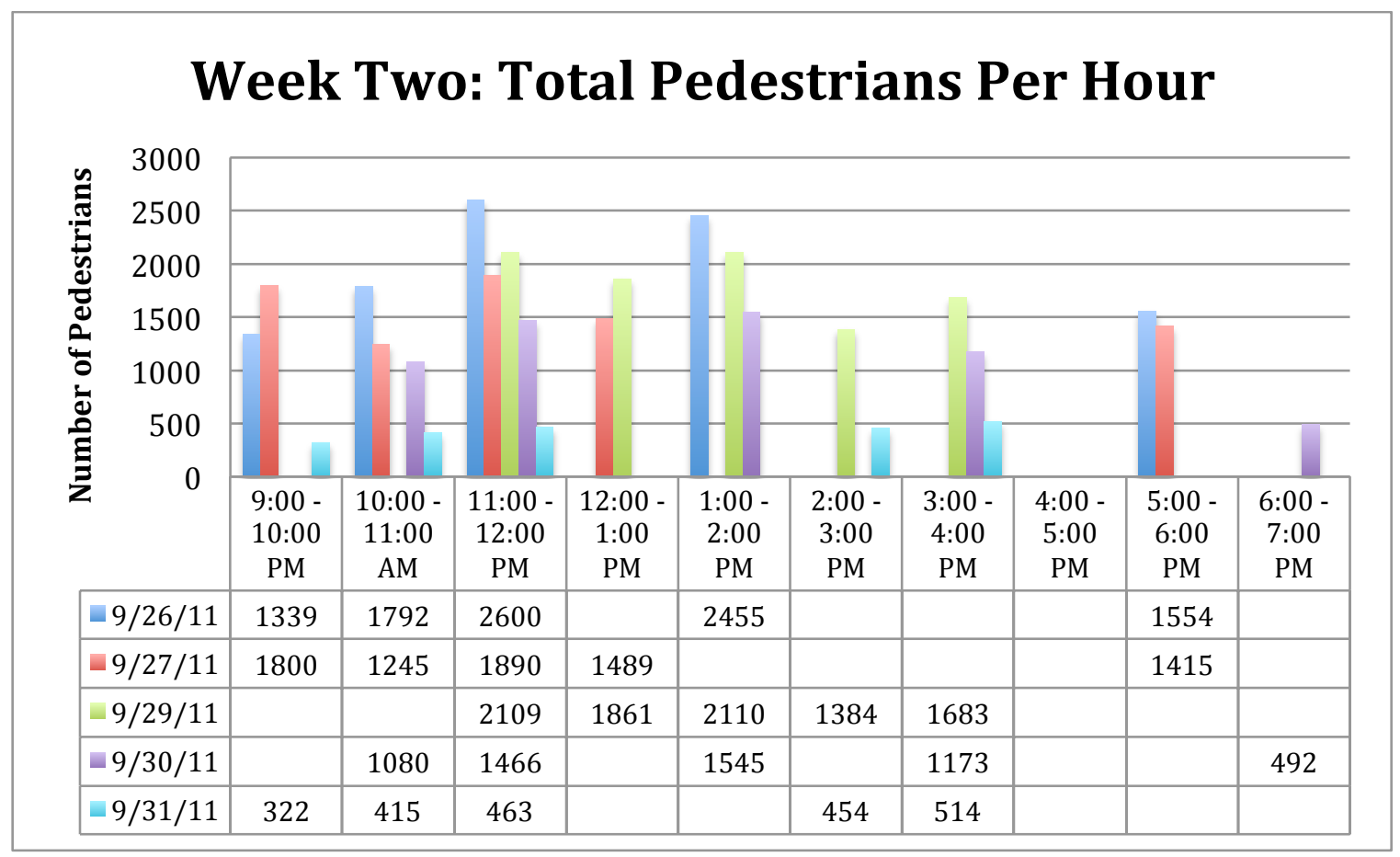

Figure 34: Total Pedestrian Counts Per Hour for Week Two

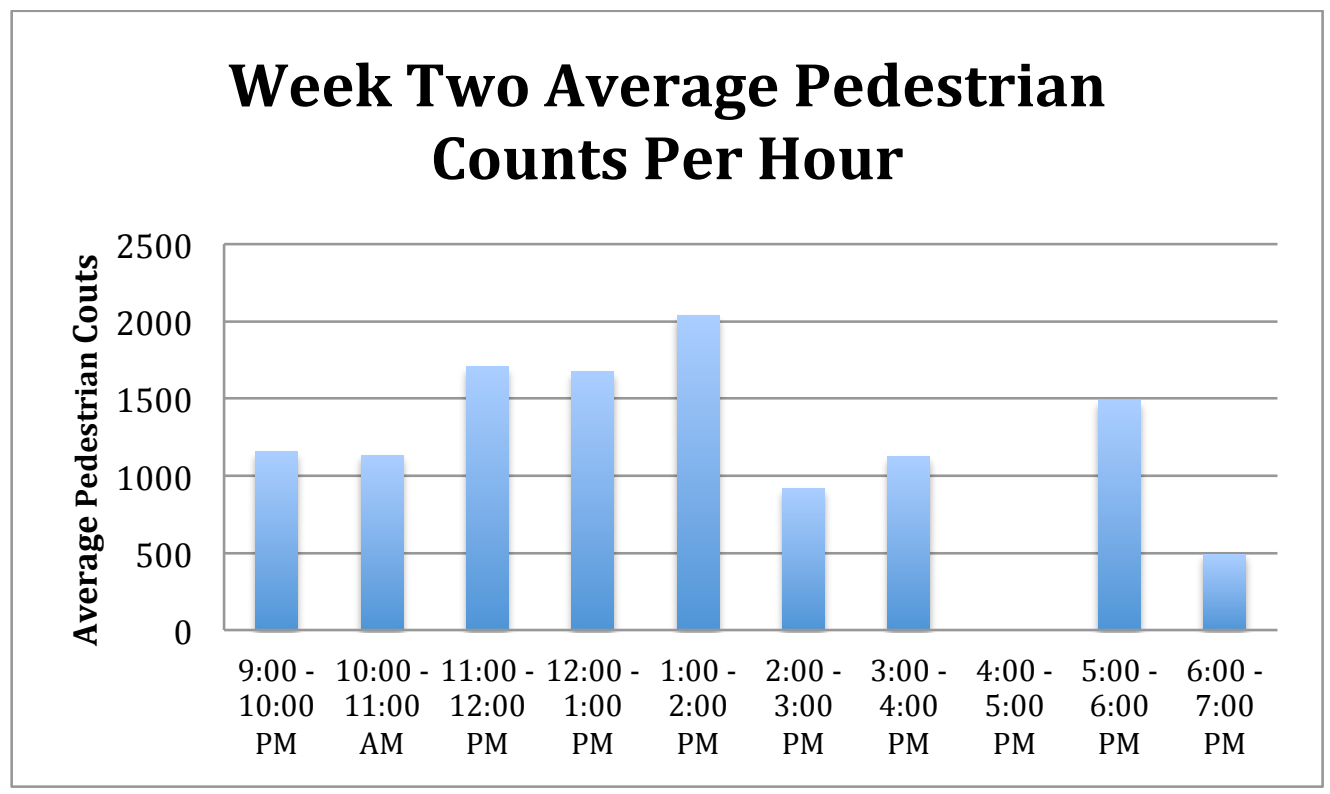

Figure 35: Average Pedestrian Counts Per Hour for Week Two 
It is easier to see the difference between the two weeks when the respective averages are compared (see Figure 36). The second week's averages are always higher than the first week's, often doubling in volume. In analyzing the video recordings, and based on other general observations, it appears this increase in traffic is linked to classes being in session during the second week. Given that school was in session, it is highly likely that many individuals exiting the light rail and traveling across the plaza were students. It is also possible that the number of students may decrease as the term carries on, though that is beyond the scope of these observations. Even if this is the case, however, it is clear that during the second week when classes were in session many more people travelled through the plaza.

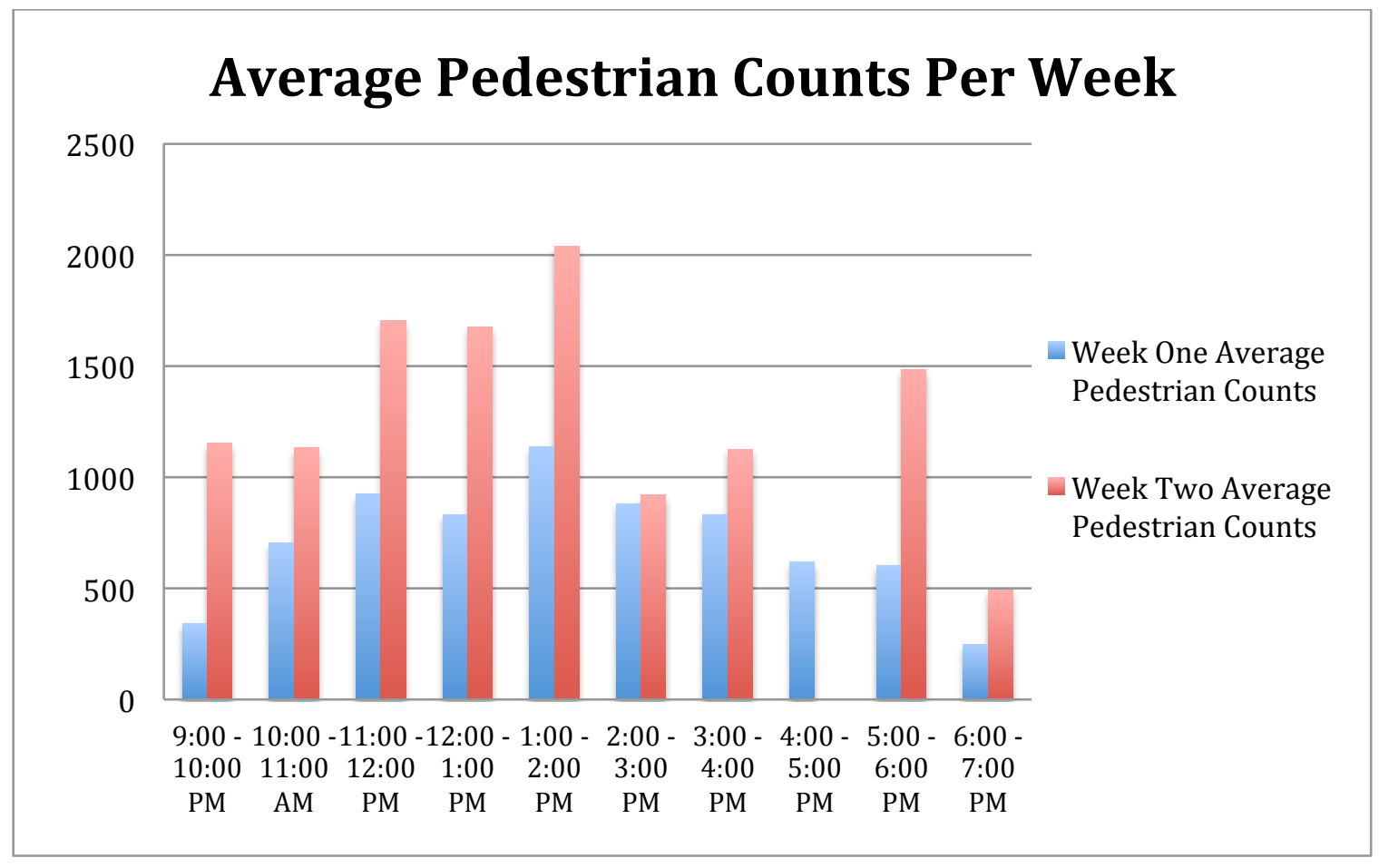

Figure 36: Average Pedestrian Counts for Weeks One and Two 


\section{Seating Behavior}

Much like the pedestrian counts, sitting and pausing behavior were analyzed by week due to the difference in general pedestrian counts between the two weeks. As was the case with the pedestrian counts, the number of sit events seems to increase around midday, specifically between the hours of 1:00 PM and 2:00 PM in both weeks (see Figures 37 and 38 for complete counts). Both weeks' counts had their highest recorded sit events in this hour. Again, this is consistent with a lunch hour hypothesis whereas not only are more people travelling through the plaza during this time, but they are also staying for a period of time, sitting on the steps or ledges and taking a lunch break. Observations during this time also support this hypothesis in that behavior was frequently individuals or small groups eating and socializing. While week two showed an increase in sit events, it was not as significant as total pedestrian counts in the plaza, though it may still be influenced by an increase in student presence (see Figure 40 for average sit events). 


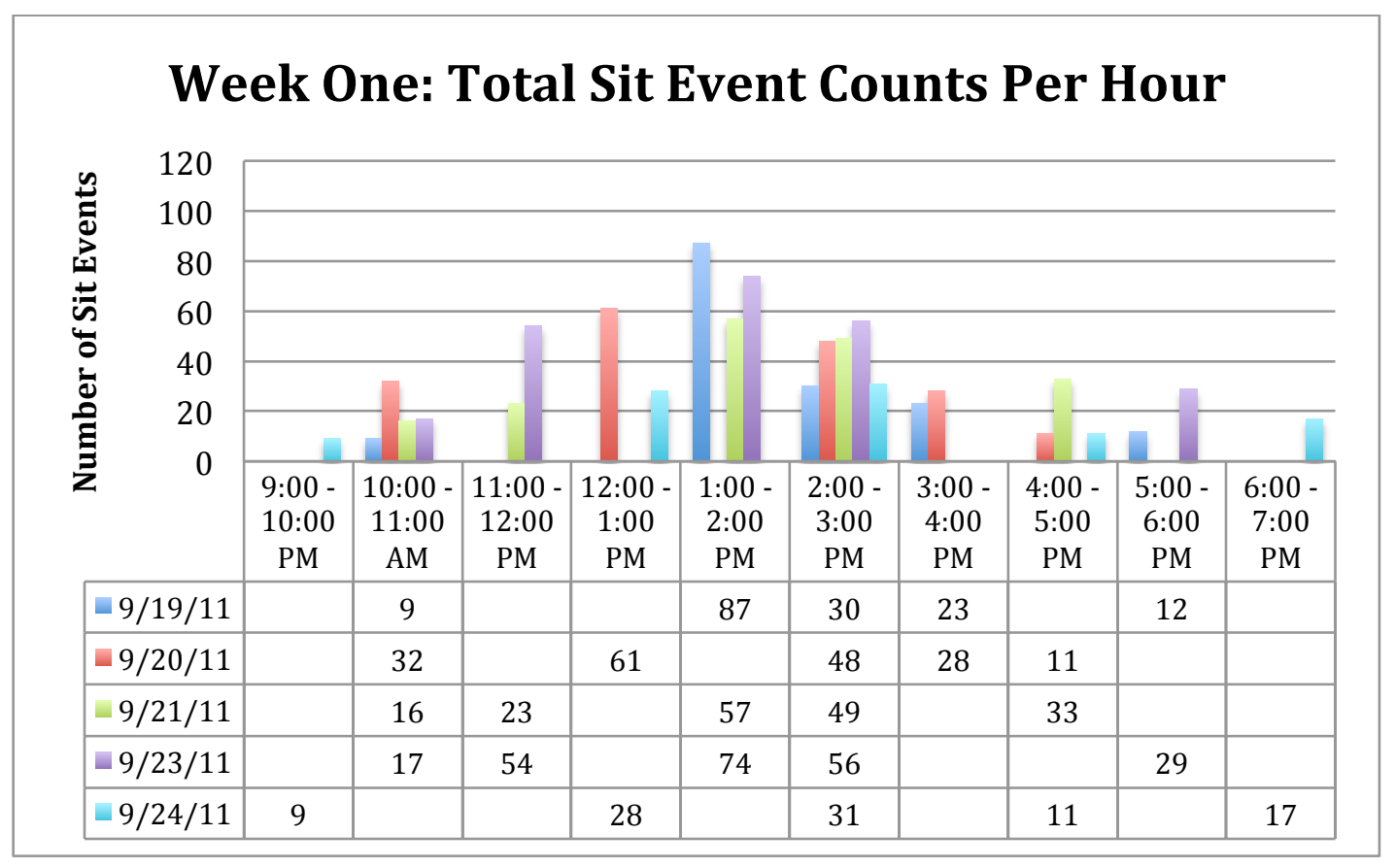

Figure 37: Total Sit Events During Week One

Mapping sitting behavior was also done by hour, marking the location of a sit event by hand, and then digitizing it for ease of analysis. Afterwards, the hourly maps were compiled into daily compositions in order to look for patterns in sitting locations. For example, Figure 42 shows the entire daily sitting and pausing activity for September $21^{\text {st }}$, the Wednesday of the first week. The red dots indicate sit events so that the darker the color, the more frequently that location was sat upon. No extremely prominent locations were sat on more than others aside from the terraced seats that were intended for such a purpose. However, as Whyte notes, people like to sit where there are places to sit, and many potentially suitable places were sat upon, even if only once during the observations (Whyte, 1990). 


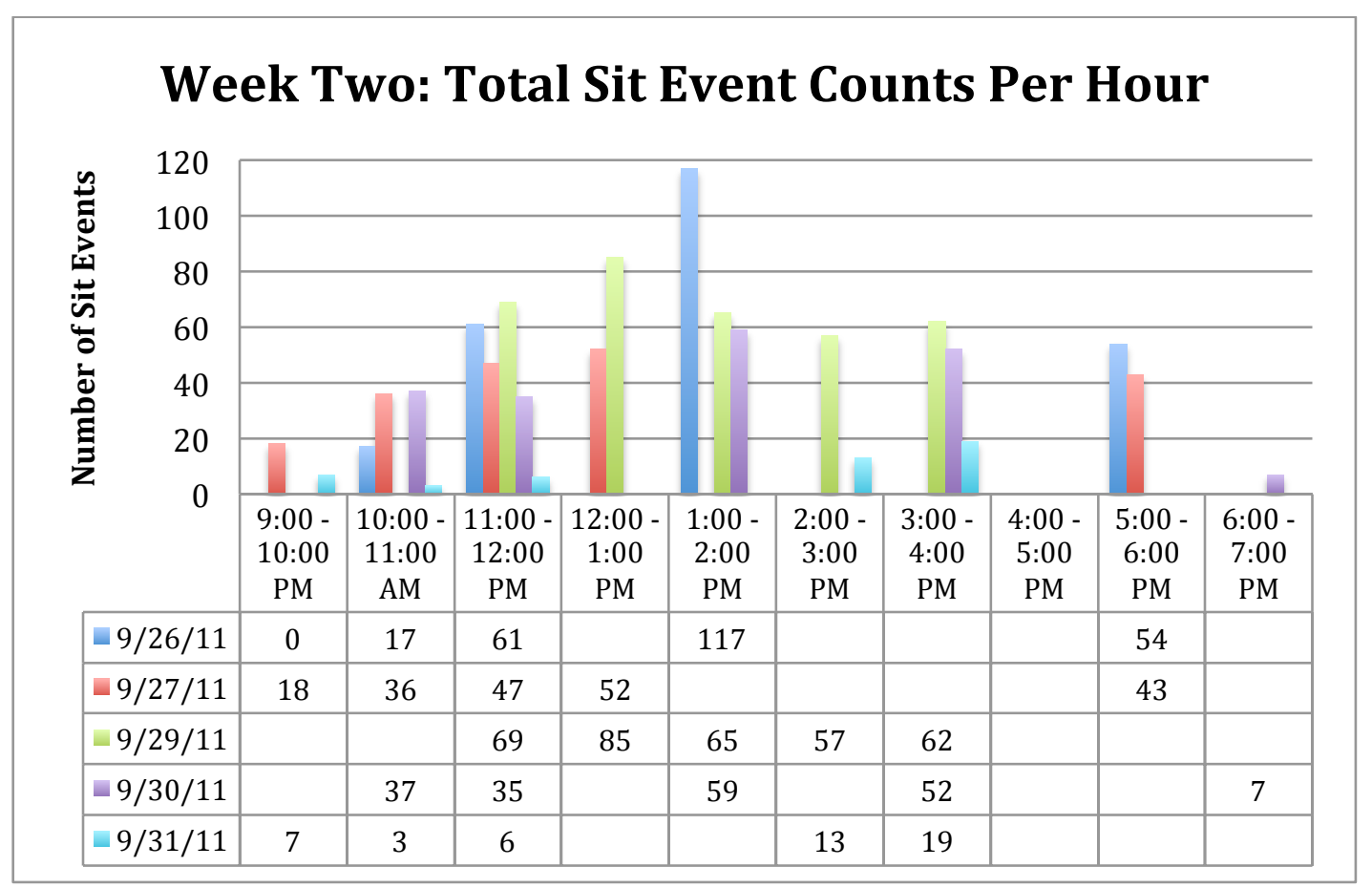

Figure 38: Total Sit Events During Week Two

It was surprising to see that the ledge around the northern fountain was a popular spot. Whyte talks about the popularity of water sounds, especially in an urban setting surrounded by bustling city noise (Whyte, 1990). It also affords a great deal of privacy with the right kind of vantage point - elevated enough to watch but not necessarily be watched, and potentially near other people but not surrounded by them as is the case with the terraced seats. Indeed, the author found this a very pleasant location due to its isolated but still prominent placement near this calming white noise. It was also surprising to see that the topmost ledge of the terraced seats was a desired spot to sit. Originally it was hypothesized that one would feel too exposed sitting on the highest spot of the main plaza, with no back to lean upon. However, it was here that people were able to absorb the most amount of sun, often lying on their back to soak it all in (while they could, that is). Some people 
also liked to sit facing the interior of the plaza, which was conducive to large groups due to the curved seating and ample space. The daily behavior map for September $30^{\text {th }}$ shows examples of this whereas every pause near the upper ledge of the terrace was connected to a seated person or group of people (see Figure 44).

The interior larger ledges of the east and west fountains were also popular possibly due to their proximity to water or the larger size of the ledge, conducive to seated parents watching standing young children as they peer into the fountains. Also of note is the lack of people sitting between the green space near the east and west fountains. While some people decisively chose these locations for quiet reading spots as was observed on a few occasions, they never stood out as popular spots to sit. While this does afford choice in seating areas, it is important to note the lack of preference, which is in opposition to their intended purpose as per correspondence with Nevue Ngan, the designers of the green space (Nevue Ngan, 2012). 


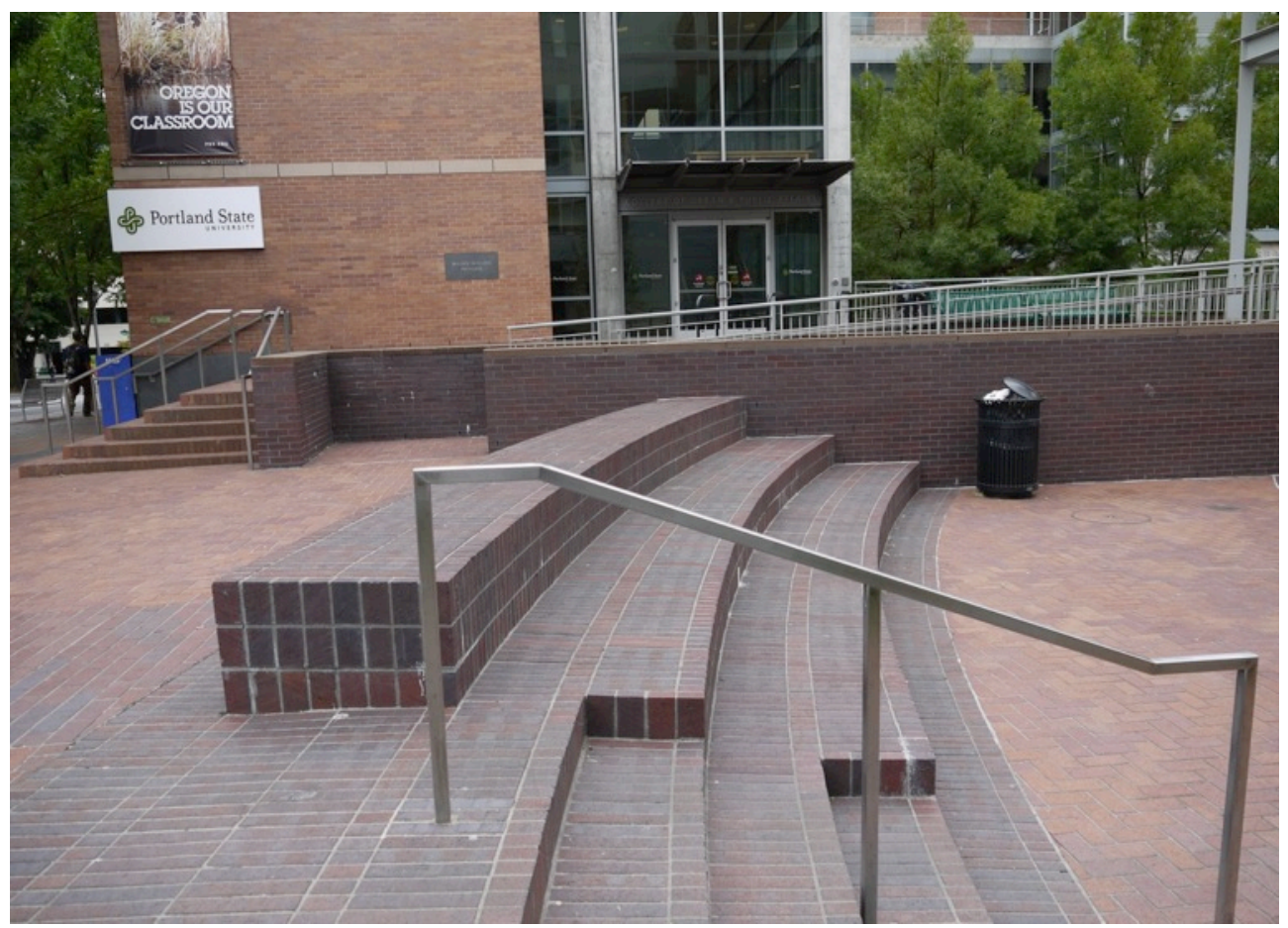

Figure 39: The less popular upper tiered seats to the west (photo by author, 2011)

Another somewhat unpopular location is the second set of tiered seats facing the plaza on the west side. This area never filled to capacity like the northern seats did, possibly because of the proximity to the looming blank wall on the side of the patio that hosts the ice cream shop (see Figure 39). In this corner, the bulk of the action in the northern section of the plaza is out of view and the only visible area is the top part of the main plaza - primarily a transitory space where people simply walk across. Some people did sit facing towards $6^{\text {th }}$ Street, though, perhaps to sit while waiting for the train. In a few instances, individuals also sat on the ground either because the group was too large to form a circle, or because all other seating space for larger groups was taken. 


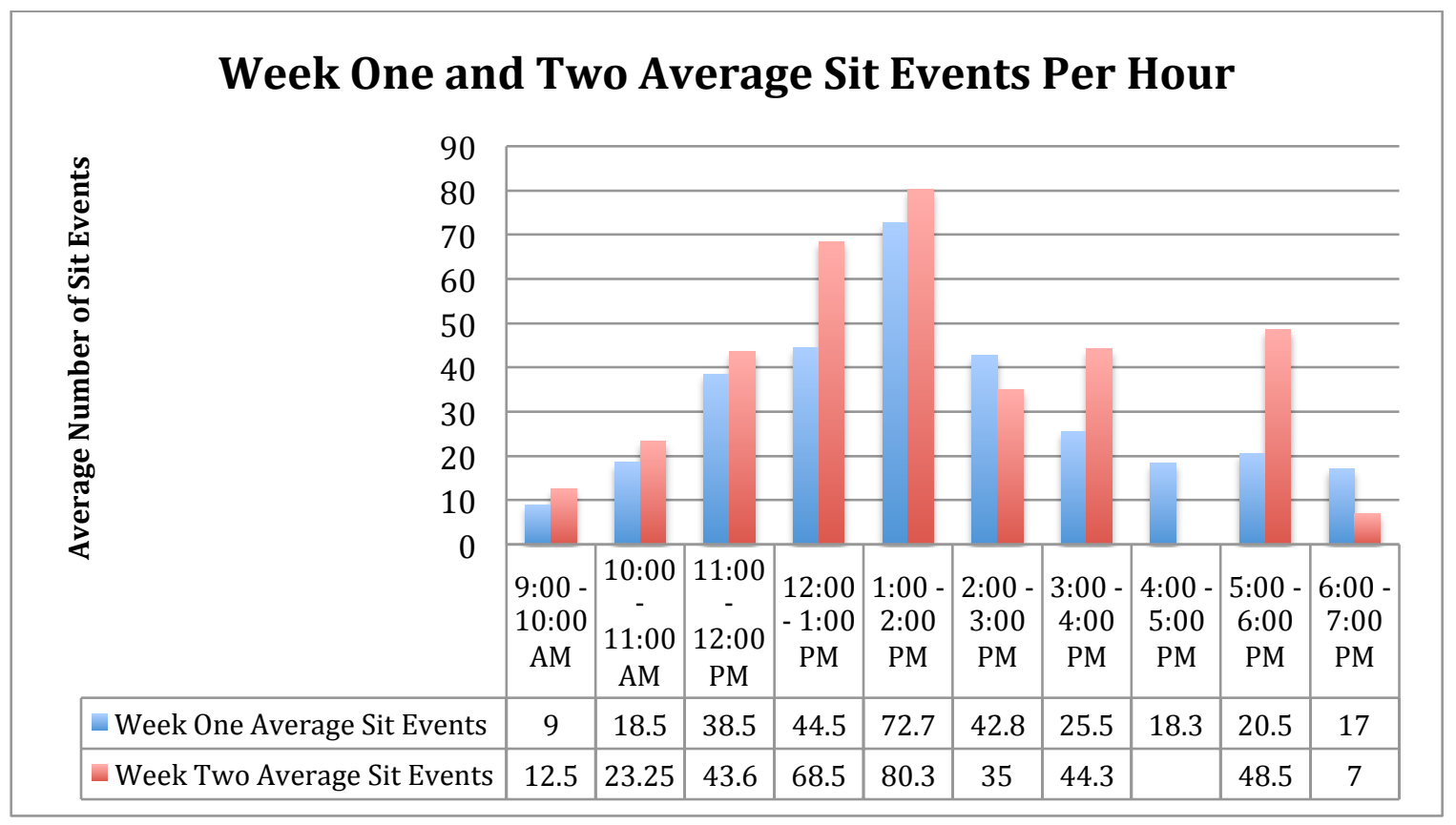

Figure 40: Average Sit Events Per Hour for Weeks One and Two

The percentage of total people in the plaza who decided to sit, too, was analyzed on an hourly basis in order to look for patterns (See Figure 41). Overall, the pattern seems to follow the total pedestrians, sit, and pause event counts whereas the amount peaks around the noon hour and then steadily declines. This implies that as more people are in the plaza, more people also sit there. However, the difference lies in the percentage between the two weeks and the late evening hour. Week one in this case has the higher percentage of people staying though it had the lower amount of people overall and the second week had the lower percentage of people staying overall. It seems this is attributed to the increase in students attending classes coming from the light rail. The increase in the evening hour ratio may be due to the lower number of people in the plaza in general, so that even a low number of people sitting would show a higher percentage. 


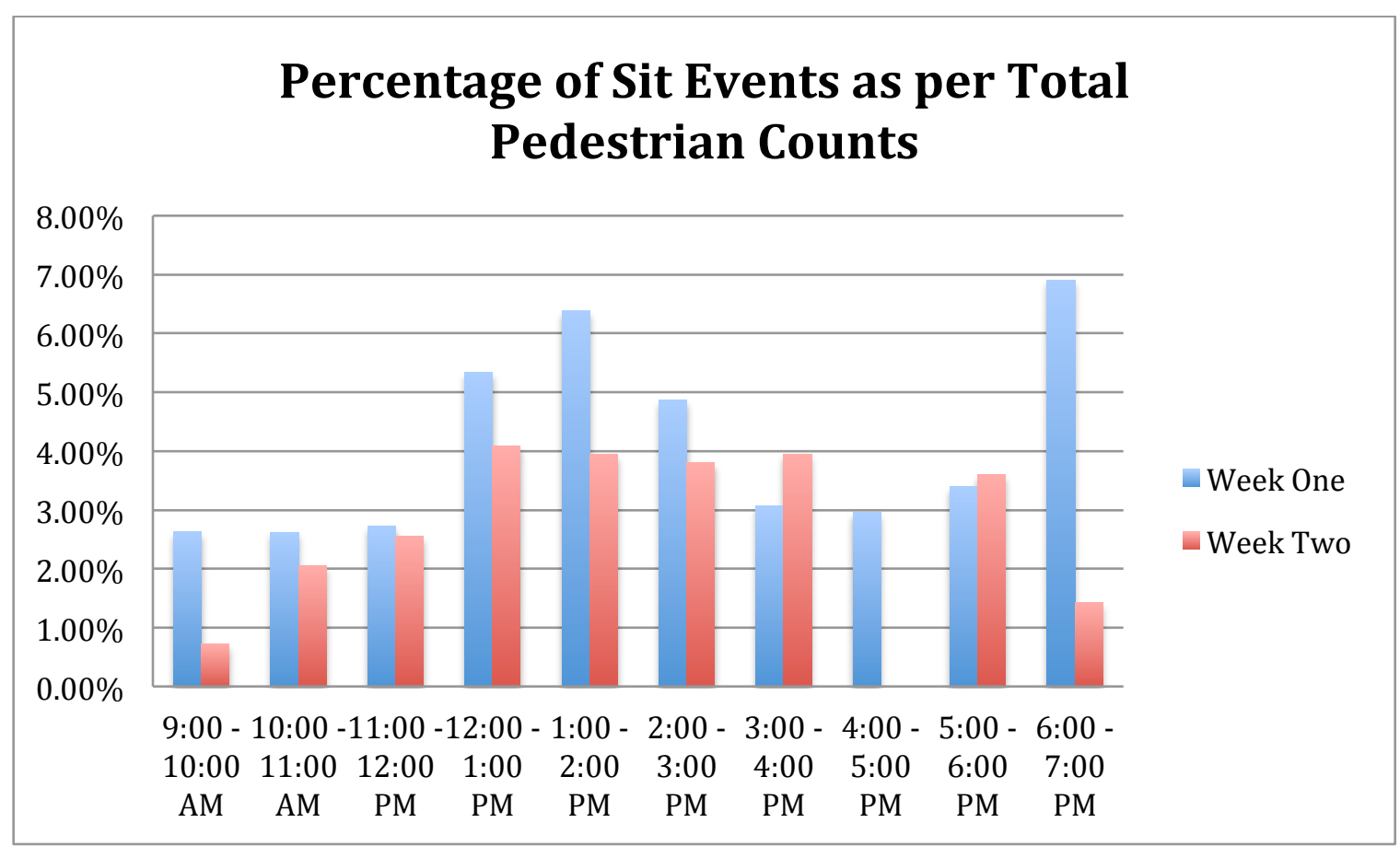

Figure 41: Percentage of Sit Events as per Total Pedestrian Counts

\section{Pausing Patterns}

Individuals stopped in place while walking for longer than five seconds were considered a pause event. Most often these were people preoccupied with their cellphone, engaged in a conversation, or meeting or leaving an acquaintance. In Figure 42 the smaller blue dots indicate pauses and lines connecting dots indicate more than one person engaged with the other/s while also paused. Once again, in organizing this data exact counts over the hours recorded were analyzed, followed by the overall average trend per week, and the two were compared. As was the case with pedestrian counts and sitting events, many more pause events occurred in the second week (see Figure 43). Further, the most common hour for pause events was the 1:00 PM to 2:00 PM hour once again (M=134.3 and 124.7 respectively). 
However, there was an outlier in week one during Monday, September 19 when 189 people paused from 1-2:00 PM due to an event being held in the plaza that day.

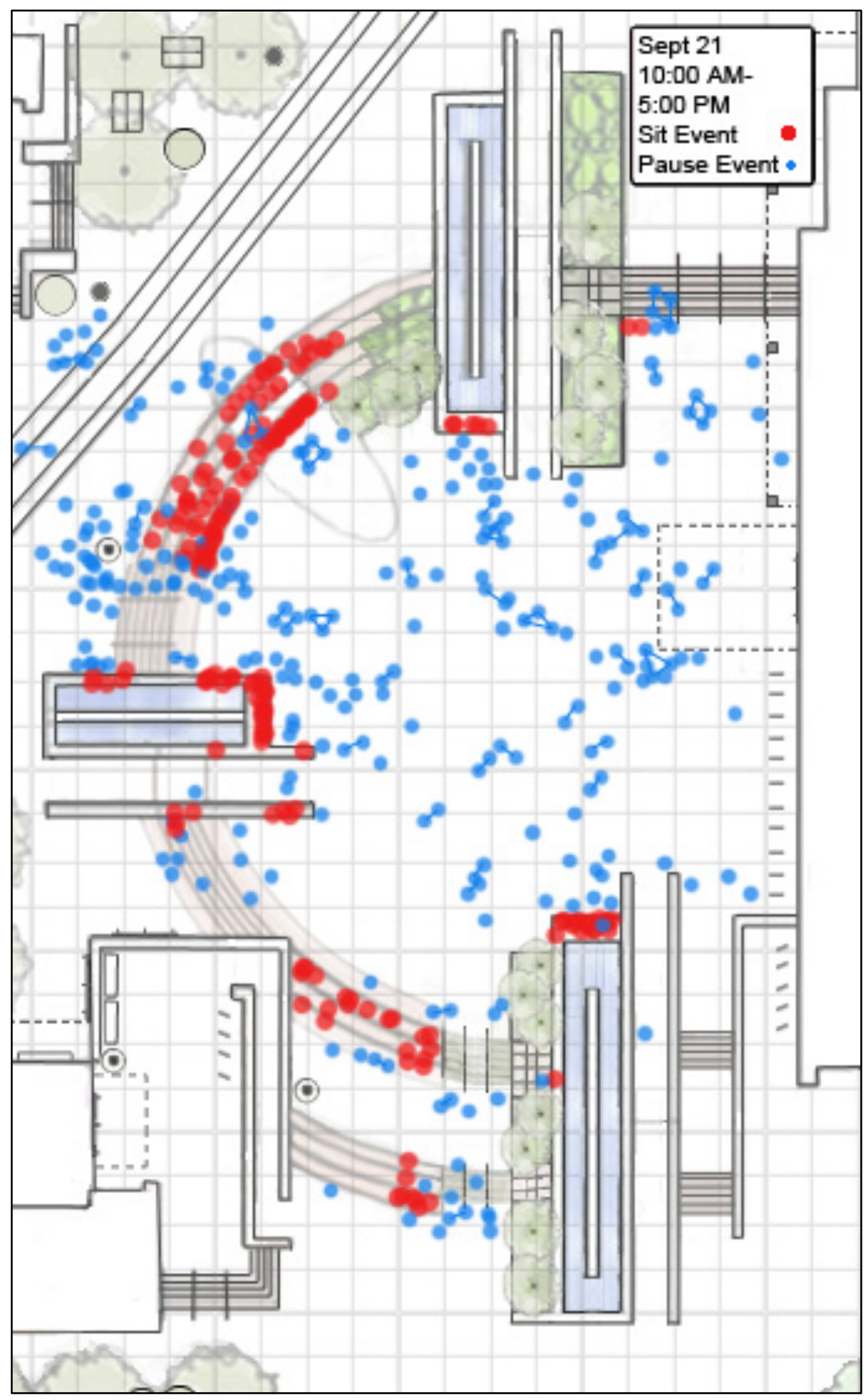

Figure 42: Total Sit and Pause Event Map for September 21, 2011 
Most frequently, people paused while walking in a decisive direction and then continued on their way after a few seconds. More often than not this meant stopping in the middle of the stairs while ascending or descending, even if there was a line of people behind them. Figure 42 illustrates this nicely. In what appears to be an orderly procession, people consistently pause on their way around the trashcan on the northern edge and on their way through the northern staircase. Note also the pattern of stairwell pausing on the east and west standard stairs as well. Pausing behavior also follows general travel paths (i.e. from the trashcan to the western stairs, or the entrance to the Recreation Center to the north and west) and paths to destinations where acquaintances are most often seated (i.e. at the interior edges of the western and eastern fountains).

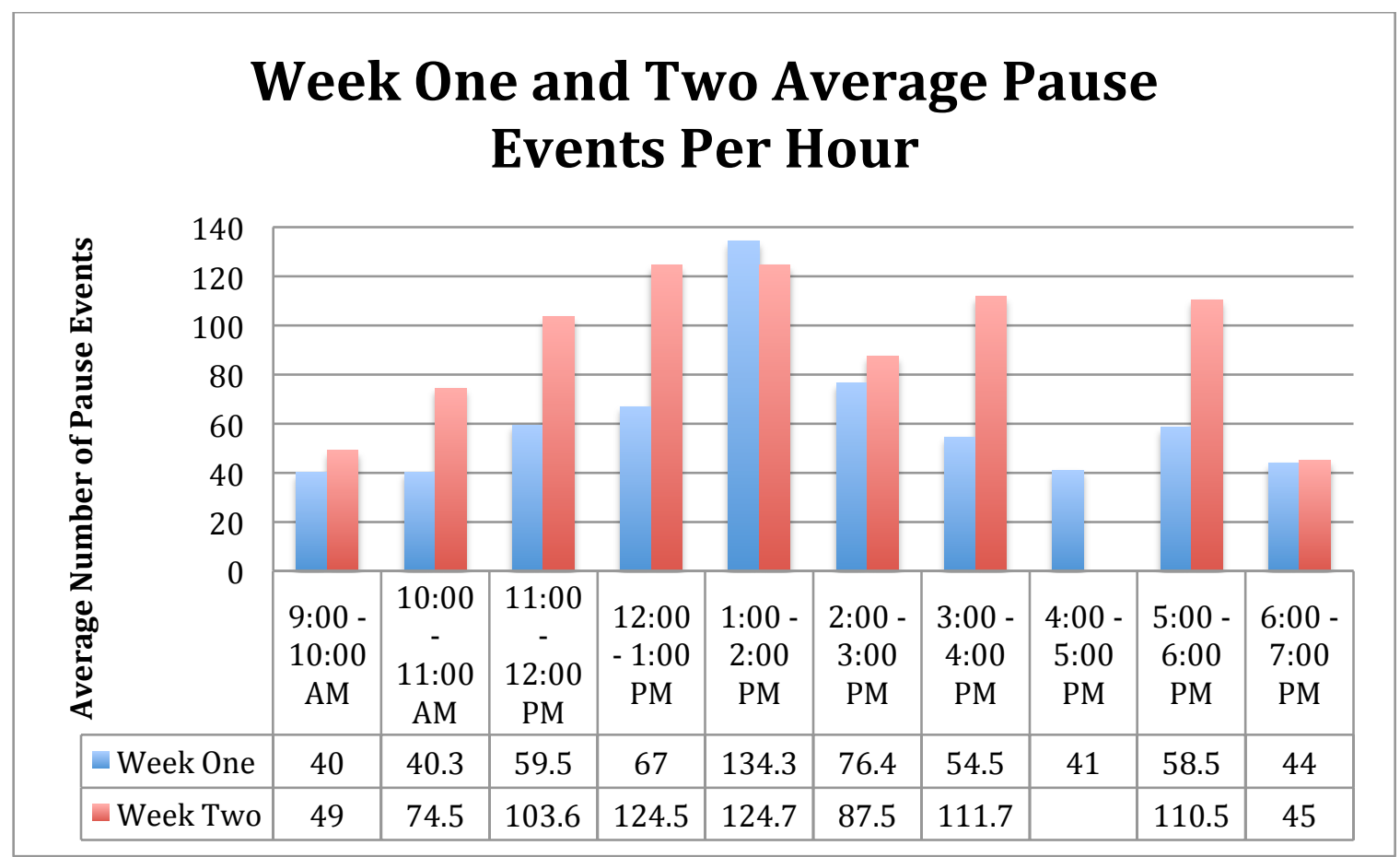

Figure 43: Average Pause Events Per Hour for Weeks One and Two 
Aside from distinct travel lines, people also tended to pause directly next to edges within the plaza. Figure 44 shows seating and pause patterns for Friday September $30^{\text {th }}$, in the second week of observations. This daily compilation also shows the higher volume of sitting and pausing behavior in the second week. It is clear to see the clumping of pauses alongside the ledges hosting seated individuals, as well as the standard stairwell pausing pattern, which in this instance is equally applicable to the ramps as well. Another "magnet" in general is the northern trashcan at the base of the stairs. Surprisingly, people did not often pause here to throw away trash, but to have a conversation instead. It was also a common place to wait for the streetcar to pass to the northwest. Though most people typically sit on the terraced seats, some also stand to converse with their seated friends for a time. Another tendency is to gather in a long conversation with two or more people directly in the way of a key travel location, such as at the top or base of a set of stairs.

Consistent with Whyte's research, this is similar to the "100 Percent Conversations" which occur in the middle of a street corner, rather than off to the side and out of the way (Whyte, 1990). The people pausing close to an edge were more often talking with someone sitting there than with someone else who was standing as well. While this is not a street corner, the same principles can be applied. The places people are trying to move through are the places where people pause. Figure 44 shows this perfect pinch point where several highly travelled corridors meet at the top of the northern ramp and in the way of the curved path from northern to western steps (see Figure 45 for travel paths and pinch points). 


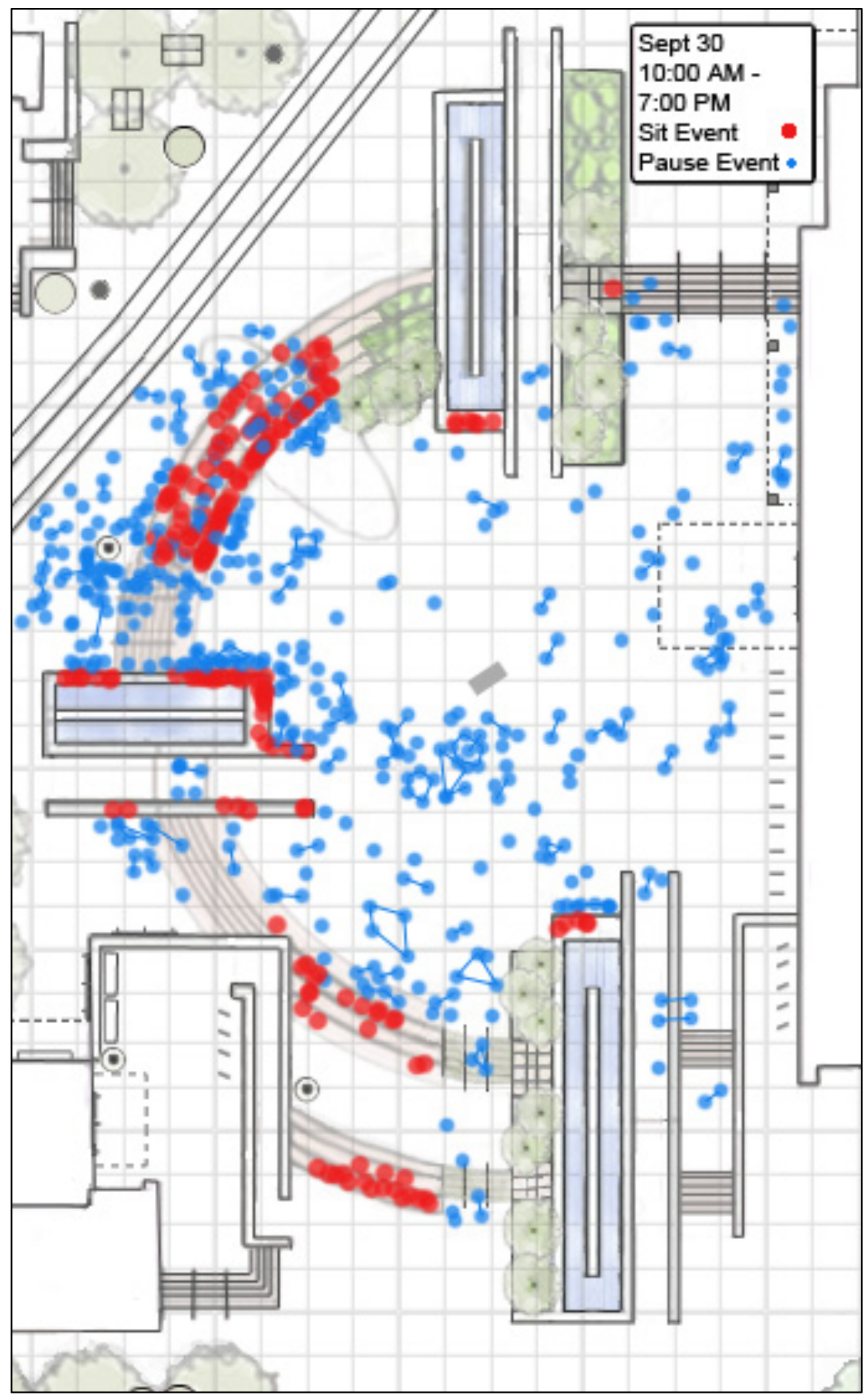

Figure 44: Total Sit and Pause Event Map for September 30, 2011 


\section{Pathways Through the Plaza}

By far, the highest number of people traveling through the plaza are those coming from the light rail stop on $\mathrm{SW} 5^{\text {th }}$ Street to the east travelling west, across the plaza, towards the campus. Figure 45 shows this complicated series of pathways typically taken by those heading east or west and the pinch points caused by the previously mapped pausing behavior. There are four major routes taken on or around the terraced seating (labeled on Figure 45): out of the way around the trashcan (1), squeezed between the trashcan and the terraced seating (2), cutting across the seating to the normal steps (3), and directly up (or down) the terraced seats themselves (4). This is one of the major design complaints by casual onlookers, though some seem to deftly (and even joyfully) navigate up and over this obstacle.

Previously, a small set of stairs occupied the space next to the east fountain where green space is now. For the average risk-averse individual, this unfortunately means a longer and awkward path somewhere near the oddly-placed trashcan in order to cross the plaza. During the peak times of the day when school is in session, nearly 200 people travel across the plaza when the light rail empties out every fifteen minutes. This can cause a somewhat complicated situation as the entire northern section is overcome with people attempting to get from point $A$ to point $B$ in the quickest way.

Otherwise, a great many people only traverse the very edge of the plaza along the Recreation Center building. A doorway opens up to the plaza's south side, and many seem to hug the wall as they are either entering or exiting, or as they simply pass from east to west. An interesting route involves the western terraced 
seating as people pass in either direction. Coming from the west, it is fairly easy to transition from the smaller steps to these larger seats in order to cut the corner faster. Alternatively, on their way up people frequently begin walking up the larger seats, believing they can make it all the way up rather easily, but then have to transition from the landing to the smaller (and much easier) set of stairs instead. 


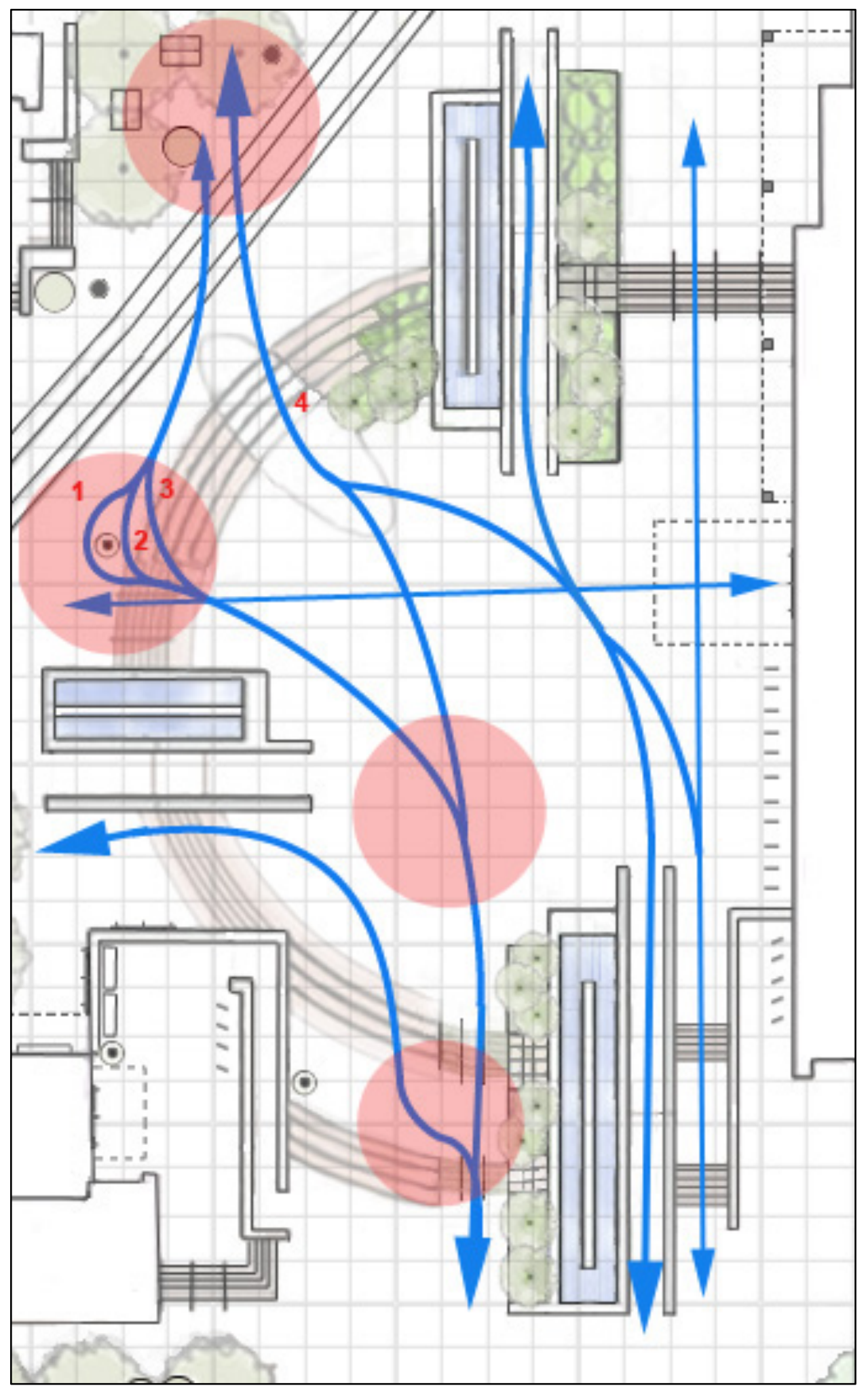

Figure 45: Frequent Travel Pathways through the plaza, with common pinch points shown in red and major westward routes numbered. 
The ramps were required in order to allow wheelchair access (Macy, 2012), but actually serve a number of travel needs. Bicycle traffic and runners were counted to analyze their travel behavior through the plaza as well. The ramps provide a seamless transition in a non-automobile space, and it was theorized the plaza would be utilized by these populations because of this. Indeed, a very common path for bicycle traffic is between the east and west ramps. Skateboarders, too, take advantage of this easy grade transition. While wheelchair traffic was not very high, this was to be expected, and one individual who frequently uses the ramps obviously benefits from their convenient presence. Those running for recreation were also not extremely numerous, but they did definitely also take advantage of the ramps. Additionally, they did seem to be of assistance to elderly individuals in need of a gentler grade change.

\section{The Daily Life of the Urban Center Plaza}

Early summer morning in the Urban Center plaza brings diffused new rays to the chilly air. A few early risers retrieve their coffee and a dog-walker may wander across the mostly empty space. If you're lucky, a person or two may be sitting down briefly on a bench or the terraced steps as the downtown Portland Clean \& Safe crew sweep by. As the morning wears on suddenly a few hundred people may begin moving through the plaza, on their way to work or an early run on the treadmill. As classes begin, a few hundred becomes over a thousand every hour rushing this way and that to avoid being tardy. All traffic suddenly comes to a stop during the lunch hour when suddenly nearly every square foot of suitable space is taken up by 
individuals and pairs simultaneously chatting and eating, making best use of the space before the line of shade cast by the Recreation Center rushes in from the south. The afternoon follows suit with a second class-rush and eventually ends with what could only be described as a near complete halt at 6:00 PM as students and faculty alike finally head home or are (unfortunately) one of the few mired in an evening class. Another dog-walker here or skateboarder there followed by the late night drunken group passing through and the plaza again comes to a close.

This Jane Jacobs-like street ballet appears to repeat endlessly, day in and day out during the weekdays, especially when classes are in session. On the weekends, the plaza appears to revert to one of its intended uses, as a neighborhood plaza for residents living nearby rather than students coming from throughout the city. Families composed of young newlyweds with a toddler allow the youngster to wobble around the plaza, attempting to gaze into the intriguing fountains. One of the most common behaviors involving young children is when their fathers lead them by hand deftly around the ledges of the fountains. On several occasions the "father and babe" near the fountains was observed. In the afternoon a group of young boys on skateboards may descend upon the plaza in order to practice their jumps. On one such day a few teenagers were observed taking advantage of the sparsely populated plaza as they practiced their jumps off the western terraced seats.

On a warmer day, the water features also provide more than just a soothing sound. Aside from the occasional curious hand in the fountain, there have also been instances of actual wading (though drinking it is explicitly advised against). Slightly older children have a tendency to run along the ledges unsupervised in a somewhat 
risky display. In a more daring event, a young woman, running across the plaza with her running partners, deftly leapt onto the western fountain's ledge, up to the higher grade, then jumped onto the topmost part of the fountain, and down to the opposite side. In no way was this an expected behavior for the plaza.

In general, many people seem to use the plaza for many different things. On one evening a man was observed on the inner edge of the eastern fountain sitting cross-legged and meditating in full view, and a couple times a few people were playing a game of Frisbee or hacky-sack in the center. The plaza is a fantastic space for children on small scooters. They can zip down the ramps, circle completely around the plaza (and their parents) and zip down a second ramp again and again. Another recreational activity observed was an interesting exercise with a soccer ball. Three boys kicked the ball towards the upper terraced steps and practiced kicking it as it bounced back towards them.

The plaza also acts as a recognizable meeting spot. A common event is that of two lovers meeting after a long class or to get lunch together. One waits eagerly while the other approaches and meets them with a joyous embrace. Conversely, the sneak-attack is another somewhat common event involving one person, normally sitting on the top most part of the terraced steps getting surprised by a friend coming up from behind.

\section{Constant Characters}

Over the course of these observations certain characters became clear, recognizable by their unique appearance and somewhat regular routines. The Bag- 
Man carries nearly ten full plastic bags - seemingly filled with other plastic bags and occasionally sits on the terraced steps, his bags set out surrounding him. He's most recognizable for his glasses, which have one side taped up giving him the appearance of a one-eyed man. When not in the plaza, he is often found in the nearby coffee shop or pizza place, and otherwise can be seen on the streetcar heading to some unknown destination.

The Coffee Deliverer, Melvin, is a physically handicapped man in a motorized wheelchair with a tray attached to it (Shwartz, 2010). Large coffee dispensers, the kind found in convenience stores or at events, sit within the tray as he wheels back and forth between the coffee shop and the small grocery store on opposite sides of the plaza. His position is unclear, whether it is officially with one store or the other, but he can be seen navigating his way through the plaza via the ramps, dutifully waiting for the ramps to clear of passengers, sometimes several times a day.

Near the grocery store, a woman is almost always found seated on one of the planters outside holding a sign asking for assistance. Around middle age, she wears an unassuming sweatshirt and has a small cart of belongings nearby. Sometimes she is joined by a man. As it is a fairly well-trafficked sidewalk, she quickly takes note of familiar faces. Even if you have never helped her before, she will recognize you with a smile and nod as you go on your way. It could be assumed that she has some sort of deal with the nearby store as other presumably homeless individuals have been escorted out of the plaza.

A more general category of character, there also exists a group of people called the Scouts. These people can be found perched upon the top step of the 
terraced steps, standing alone and peering out over the plaza. Sometimes these people stand in place for a comparatively long time, no companion in sight, no other activity taking place other than them surveying the space. It doesn't even seem as though they are waiting to meet someone - more often than not this ends with them simply stepping off the ledge and walking through the plaza as though nothing ever happened, though they are occasionally joined by their friend.

A counterpart of this character is the Drifter. This person is most often on their cellphone engaged in a lengthy conversation no doubt while on a break from work or school. It is strange for them to be standing still - sometimes the entire plaza is covered by their conversational meanderings. Often they are the only ones to spend any measurable time towards the center of the plaza. This can go on for nearly a half hour. On one occasion an individual meandered around the edges seemingly either taking it in or looking for a place to sit to no avail. After this lap they apparently decided that nothing was satisfactory. If every winding path made by these people were detailed, indeed the maps would look far messier than they already do.

Signature-seekers also make full use of the plaza. Sometimes they wear a bright shirt and attempt to nab you as you enter the plaza from the street. They always sport a clipboard of course and appear to be fairly young, likely college students trying to get some supplemental income. Depending on the organization, they may want you to sign-up and start donating, other times they're simply trying to get a measure on a ballot. The professionals capitalize on the ebbs and tides of the plaza, standing in the direct path of the stream of light rail traffic reaching out to 
passersby, or during the downtime, approaching individuals seated in the plaza for a more casual conversation. Typically, this is an activity during the beginning of the term when students are fresh and numerous, and good weather obviously assists in their success.

\section{Conflict in the Plaza}

Despite the large amounts of pedestrian traffic, sitting and pausing events, and the other forms of transportation which share the plaza, conflict is relatively low in regards to these populations converging in this space. An actual collision was never witnessed between the many wheeled forms of transit and pedestrians (including the streetcar). However, there are some social and design-related concerns regarding the Urban Center Plaza that have been observed and have also been discussed by others.

\section{Design Concerns}

While a collision never occurred on one of the ramps during the observations, there was a frequent conflict of space due to the narrow size available for traffic (see Figure 46). Reasonably, the 72" width (not including railings) can only accommodate one wheelchair, bicycle, person with luggage, or bike cart on the east and west ramps at a time. Fairly frequently it would be the case that a group of people would be walking up a ramp, and a descending bicycle would be forced to do laps around the open space or wait stationary at the top while waiting for the ramp to be cleared. While bicycles were not initially considered the major users of the ramps, and this is by no means a life or death situation, it is a common issue in the 
space. At times, it is difficult for the bicyclist to continue their motion due to pedestrians in the plaza, and near misses have been witnessed. The Coffee Deliverer also has waited on more than one occasion for the ramps to be cleared before traversing them.

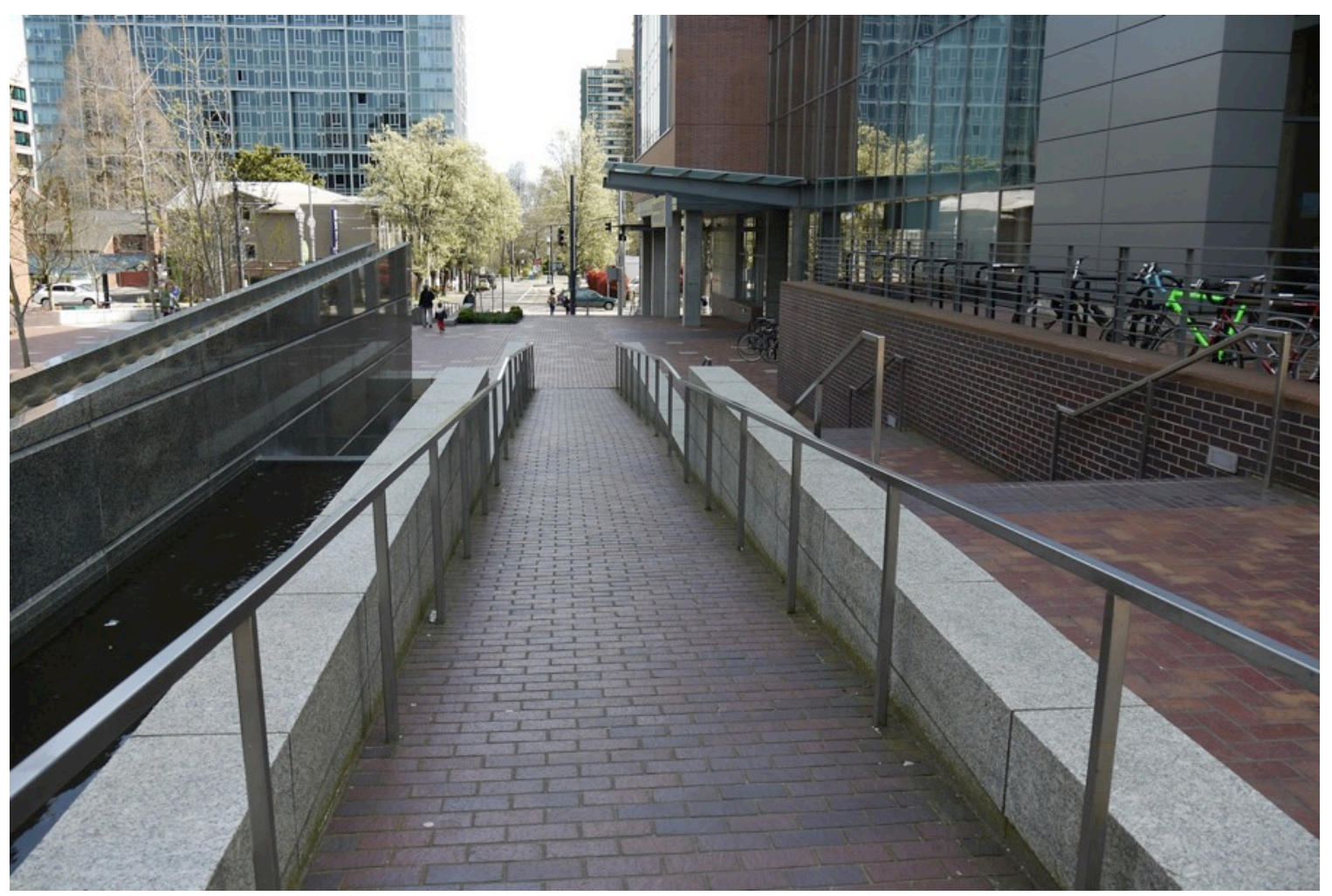

Figure 46: Ramp and west side steps looking east (photo by author, 2012)

Textures in the plaza are an oft-overlooked design concern that is crucial for handicapped individuals. The brick paving that covers most of the plaza is interrupted at various locations by an art installation by John Aiken, the most significant art installation in the city of Portland since it's famous Portlandia statue (Portland Development Commission, 1999). The oval shapes change the paving material which can be confusing for blind individuals attempting to traverse along guidelines in the ground. Typically paving types change as one gets closer to the 
road where it is dangerous. Blind individuals were observed to note the difference in pavement types and stop in their tracks, seemingly baffled by the inexplicable, and technically nonexistent, border.

On the northwestern corner of the plaza is a more drastic change in pavement. Another component of the art installation, the pavement surrounding a large granite sculpture suddenly changes to rough-hewn cobblestones (see Figure 47). This is difficult to traverse again from a blind person's perspective, but also makes it difficult for carts or wheelchairs to travel over the bumpy surface. Deliveries wheeled in to the nearby pizza place cause quite a stir, emitting loud noises and jostling food items as was observed on multiple occasions. A further potential conflict is the area around the streetcar tracks. No bright colors or drastic change in pavement, other than a smoother surface, exists to guide the blind away from them. However, the streetcar moves relatively slowly and also emits a noise when pedestrians are near the tracks, which seems to be efficient enough. 


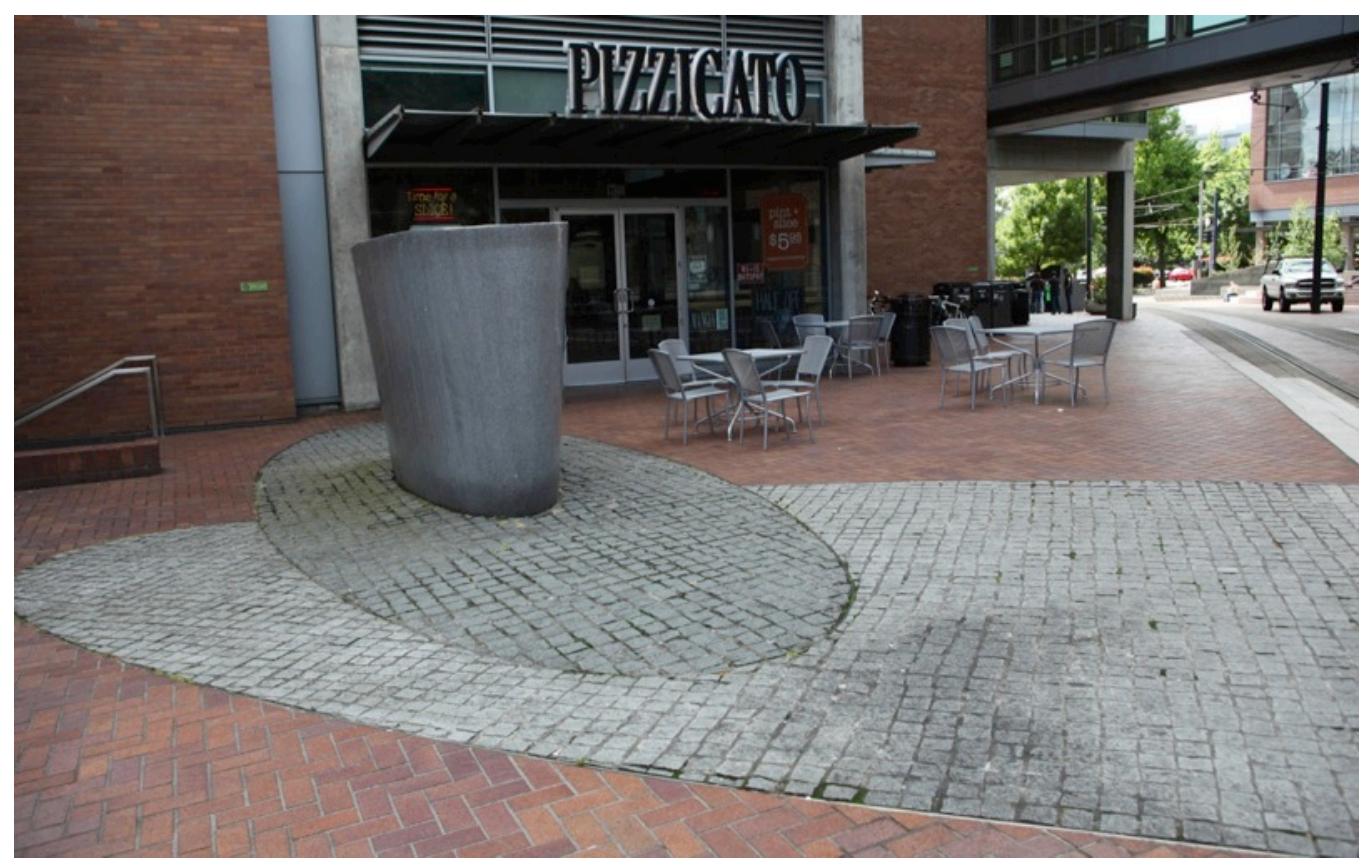

Figure 47: Cobblestone section of northwestern corner (photo by Doug Macy, used with permission)

The granite sculptures also pose other problems in the plaza's space according to the observations. Along with the oval shapes in the pavement, two large shaped granite sculptures jut out of the ground; one in front of the Urban Center's main entrance to the north of the upper plaza, and one on the northwestern corner by the streetcar stop and pizza place. Smaller versions of these also repeat throughout the Urban Center building.

The northwestern sculpture is a towering stone, oval in shape with smooth sides (see Figure 47). It is difficult even to touch the top where the stone suddenly becomes rough-hewn. Unfortunately, this sculpture is directly in the path of this entire section. One must navigate around the sculpture and the tables and chairs of the restaurant in order to get to the northernmost steps or even to the entrance of the pizza place. People waiting for the streetcar don't even find it convenient to lean 
against, and if one sits on the northern low wall to wait, the sculpture completely blocks one's view.

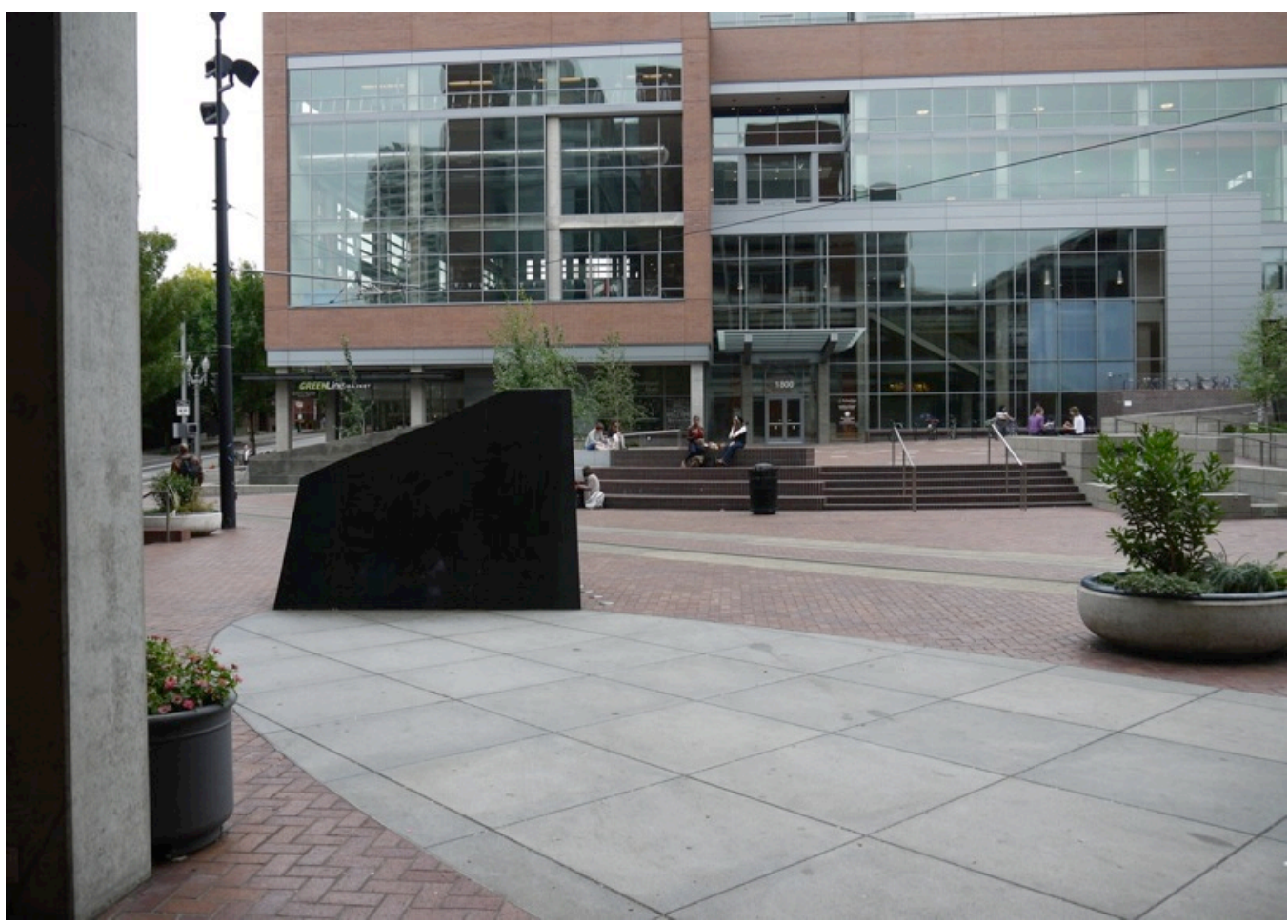

Figure 48: View from the entrance of the Urban Center building looking south, granite sculpture on the left (photo by author, 2011)

The area around the second granite sculpture located near the Urban Center building's entrance is also problematic based on recent observations (see Figure 48). As of phase five, there are now two rows of bicycle racks to the right of the entrance, with the sculpture very near to the end of the second row (see Figure 49). This conflict is due to the introduction of the new bicycle racks blocking traffic moving in and out of the building, the proximity to the streetcar tracks, and the bicyclists who are pulling in to lock up their bike or starting on their way again. A very common sight in the video observations, though not observing this area directly, was the distinct curving motion made by cyclists as they moved around the 
sculpture and between it and the streetcar tracks (which are dangerous for cyclists' wheels). From the perspective of the video recordings, cyclists would be seen in the lower left hand corner (see Figure 30). As for the sculpture itself, the sloped top is still fairly tall and does not invite one to sit atop of it. There was observed one very ambitious child scale the top of the stone, though this was the only interaction with it witnessed aside from skateboarders (she also jumped into the northern fountain and ran up and down it - in plain view of her parents who didn't seem to mind).

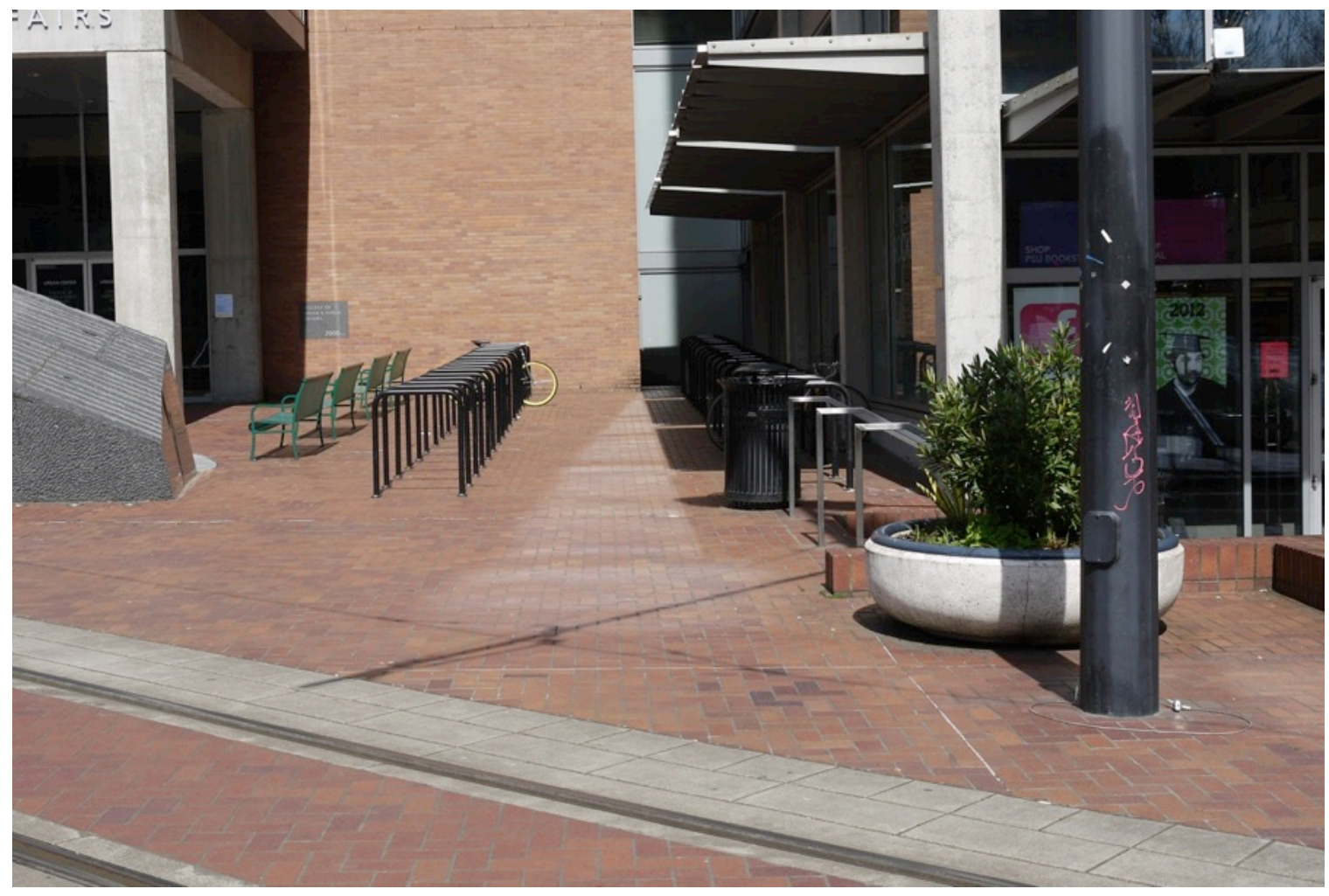

Figure 49: Phase 5 bicycle rack addition and street furniture rearrangement (photo by author, 2012)

Once again, one of the major design complaints of the space, especially for those who experienced the plaza before the stormwater retrofit, is the eastern green space on the upper plaza. Where once there was a set of normal steps providing access through the plaza for those coming from the northeast (and more specifically 
the light rail stop), now there sits a tiered set of drainage systems filled with grasses and aspen trees (see Figure 22). This forces the hundreds of people streaming from the light rail to divert west towards the northernmost stairs, or to attempt to climb the large tiered seats. Further blocking access is an oddly-placed trashcan which forces people to squeeze between or go even further out of the direct path and walk around it, which often includes navigating around the people that tend to congregate around the trashcan as well (see Figure 45 for travel patterns).

Though some people are adept at and probably enjoy travelling up the large tiered seating, and though they would possibly travel up (or down) them regardless, the removal of stairs from this section of the plaza appears to have made this an inconvenient (or at least lengthy) journey for those that choose not to or are unable to take the more direct route. Casual conversations and interviews support these common complaints.

\section{Publicness of the Plaza}

One of the key criticisms of public space, and privately owned public space in particular, is the expulsion of undesirables from the area, either directly or indirectly. The right to the city speaks to this in that every person should be allowed to use a public space as part of what is for some people the only open space they have access to. In the case of the Urban Center Plaza, the space is owned by the university and as such is technically a privately owned public space that can be managed as they so choose. While one of the goals of the space was to provide a plaza not only for students but also for residents nearby, the university can still pick 
and choose who and what they want to allow in that space and when. One of the deciding factors by the city for allowing the closure of Montgomery Street was the fact that this plaza would act more as a neighborhood and public plaza rather than a private enclave for the university only (Portland Development Commission, 1999). In looking at what is referred to as the publicness of the plaza, drawing from the right to the city, the following observations were made regarding possible conflicts towards this goal.

On one occasion, the video recordings captured what was presumably a homeless man being removed from the plaza by police. The area on the southern edge of the upper plaza along the Recreation Center building is covered by an overhang and therefore sheltered from the rain and relatively out of the way. This man was sitting on the ground underneath, but causing no apparent problems. At times, police cars have been known to drive on the streetcar tracks through the plaza, presumably as either a shortcut or as part of their enforcement of the space. The Urban Center building is technically open to the public, and police enforcement can sometimes be seen checking on the second floor bathroom. It is unknown whether this particular action in the plaza was requested by someone who called the police, or if it was campus security or the city police, but the officers parked their car near the tracks and approached the man in order to make him leave the space. The city previously had a sit-lie ordinance preventing people from sitting or lying on the public sidewalks, though this has expired as of this writing. It is possible the homeless woman near the grocery store is allowed to be there due to her position on the sidewalk, as opposed to the man on the plaza, which is University owned. 
Skateboarders are another outcast group in this public space. While no official signs are presented to the user of the space displaying prohibited behavior, a few somewhat subtle signs do exist embedded into the ground which explicitly state "no skating" (see Figure 50). Some may not see this sign as they are simply moving through the space, but the rule is in place and police have been known to enforce it. To deter skateboarders from "grinding" on the surface of the tiered seats, metal brackets are installed on the art installation section of the lower step (the large white oval area). Skateboarders have also been known to jump off of the granite sculpture near the Urban Center building, as has been observed on a few occasions.

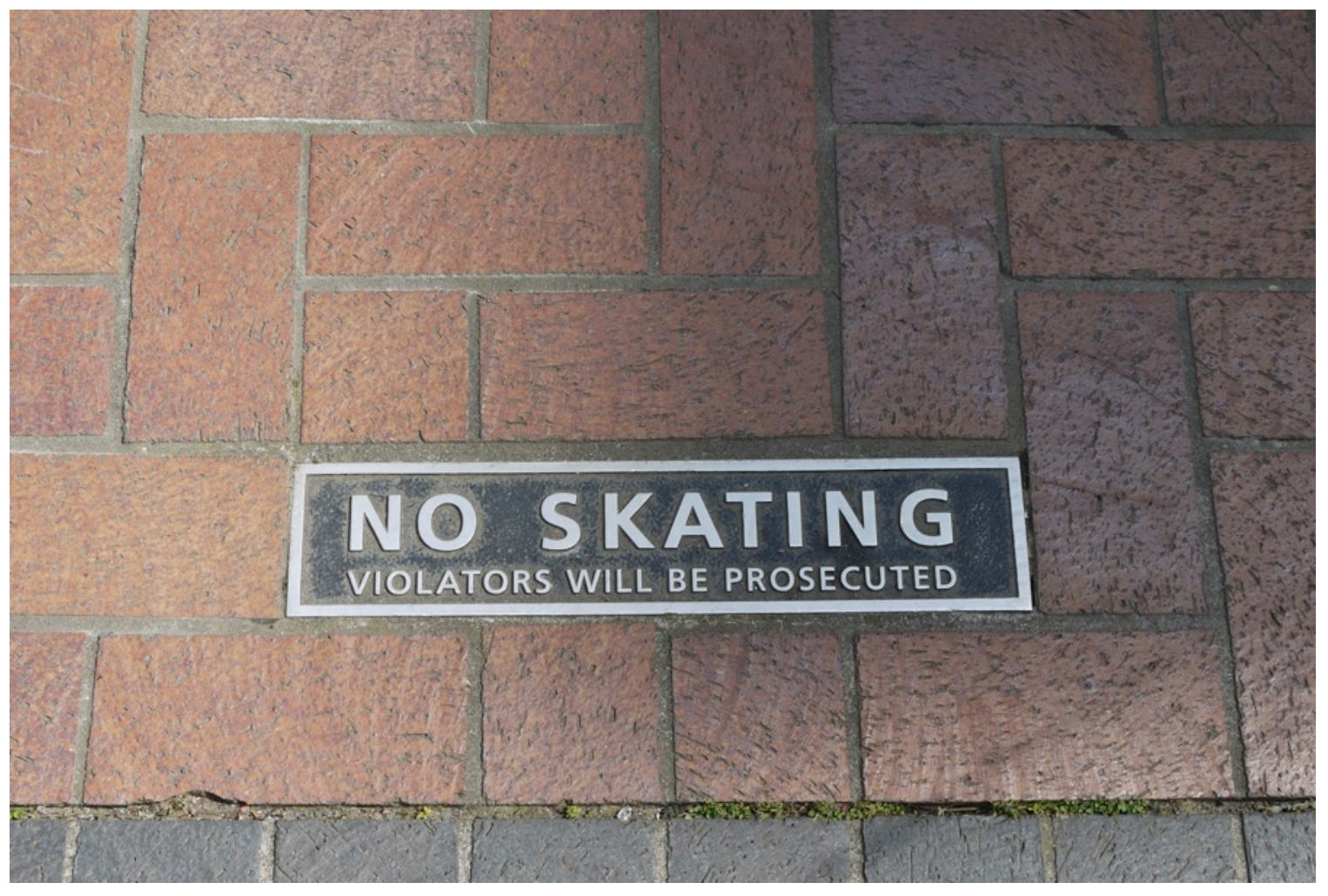

Figure 50: "No Skating" sign in pavement on west side of plaza entrance (photo by author, 2012)

More frequently, though, skateboarders have been observed using the upper plaza in order to practice tricks while simply moving across a surface, or jumping off 
of the western tiered platform. One time a skateboarder was a young child as part of a large family, simply coasting along the upper plaza. Often people on skateboards use the plaza during the weekends or in the evenings when there is little activity or pedestrians to come in conflict with. Alternatively, they also sometimes pass through the plaza via the ramps, much like bicyclists do. It was never observed that a person on a skateboard (or a cyclist) collided with a pedestrian or caused any sort of altercation. The question then is with the addition of the skateboard deterrents and social pressure against damaging the public art, along with the police presence to ensure these more costly sculptures are not damaged and their normally unobtrusive choice in time of day to practice tricks, do "skateboarders" as a group need to be expelled from this space? Still, the social stigma remains and the existence of skateboarders in this space is a topic of complaint.

The ability to manipulate the space is another point of concern regarding the publicness of the space. This is more an issue of management again, as opposed to a design feature per se. The space is almost completely devoid of graffiti or other forms of insurgent public space such as sticker art, yarn bombing, or even chalk (Hou, 2010). Poles in the space are made of metal (for the streetcar or lights), and rarely have posters on them. Whether or not this is allowed, frequently only the tape holding the corners of the poster remain shortly after the poster was put up, and recently one case of graffiti was observed on the pole as well (see Figure 49). No community signboard exists in the space, though a university noticeboard is in the lobby of the Urban Center building's first floor. While the water is touchable, the granite sculptures don't invite interaction other than passive observation. Many of 
these features are mentioned by the likes of Whyte when describing what makes a public place successful: ability to touch water, interaction with public art (i.e. climbing on it, some sort of motion, or just dual-purpose functions such as an artful seat), and manipulability of space (such as adding posters for announcements, moving chairs to the sun, etc.) (Whyte, 1990). Others even argue that the addition of things like yarn-bombing can make a place more pleasant and add a sense of place (Hou, 2010).

The democratic use of pubic space is equally important and related to this notion of manipulating the urban environment. While friends and families gather to talk and eat in the plaza, other democratic events have been spoke of, but only one large gathering considered a democratic use of space (for protesting purposes) was witnessed. As part of Occupy Portland, a smaller group of Occupy Portland State formed and held their first general assembly in the upper section of the Urban Center Plaza. Speakers stood atop the northern fountain to address the crowd and make notes on a whiteboard. These events are difficult to pinpoint, however, so other democratic gatherings have occurred here over time, but the specifics are unknown regarding events other than this one.

However, the university posted guards near the doors of the nearby buildings and checked for student identification if they wanted to enter. Though open to the public during normal hours every other day of the year, this gathering of demonstrators (mostly students) in the plaza prompted a defensive response. Demonstrators debated whether to move to a building or a covered area somewhere, but were deterred by the university's efforts. It is possible the 
university was worried about this large group containing demonstrators who were potentially not students or violent. While the university seemingly allowed the plaza to be used as a democratic gathering space, it does question the willingness of the university to allow this kind of behavior.

\section{Comparison with Past Research}

The Captsone course's earlier results showed that the plaza was an underused space, emphasized as a transitory space, and not conducive to gathering or staying behavior because of the exposure and barren nature of the upper plaza. Their research, however, was during the middle of the summer which may have decreased the number of people using the plaza due to summer classes and higher temperatures. By using time-lapse video, they also left out people simply passing through the space, further affecting the total accuracy of their analysis. It's also possible that the completion of the Recreation Center building, not present during their observations, has impacted the increase in users of the plaza.

The criticism they present regarding the transitional nature of the upper plaza, whereas people mostly pass through the space rather than stay there, was actually the intended use of that section of the space by the designers. Other areas in the northern section of the plaza are intentionally designed to be gathering areas on the edges, including benches, larger trees, and planters. The restaurants also provide seating areas for patrons that are sometimes used by non-patrons alike, and the addition of green space in the upper plaza has satisfied the need for more pockets for passive activity (as was also requested by the participants of their 
survey). The handrails on the stairs, which they criticize as encouraging the transitional nature, are most likely required by the ADA, much like the ramps themselves (Macy, 2012).

The lack of shelter and formal seating in the upper plaza (aside from the many ledges used as seating) reflects the designer's intent of the space as also being used as a large gathering area for events. The university has used this for events, including a back-to-school event in the fall term, but does not seem to utilize the space very frequently. During the observations, the most common use of the space by the university is in the form of an A-board advertising the Recreation Center, welcome-back events during the first week of the term, and occasionally a tent for a car-sharing program. The College of Urban and Public Affairs used to have graduation ceremonies in this space, but no longer does do to size restrictions.

It does seem in the observations that most people coming to the plaza are either students from Portland State University and the nearby private high school, shoppers at the bookstore and nearby stores, users of the Recreation Center, or faculty and employees of nearby establishments in general. However, there is a decisively different set of people who use the plaza on the weekends and evenings as opposed to the noon hour during weekdays. As the Captsone group's observations only covered a limited amount of time and did not observe weekends or evenings, they may not have drawn this conclusion. Further, it may be the case that over time as more people are aware of the plaza and as more housing has been built nearby, more people other than students now take advantage of the space. 


\section{Chapter 5. Discussion and Conclusions}

By analyzing the Urban Center plaza in more detail, using quantitative and qualitative methods, and by spending a greater amount of time in the space, a spatial ethnography of this place was conducted in the context of the city, university, and current stage of development. Through the methods chosen, goals of this project were realized, after the interviews and previous research provided insight into how the plaza came together and observations showed how the university and neighborhood use the space. Continuous video observations made it possible to analyze in detail the behavior in the space, in the context of a pleasant time of year and when classes were and were not in session. Casual conversations, in-person observations, and previous research provided supplemental information on the opinions of the space. Changes over time were discovered through interviews and comparisons to previous research. By conducting this analysis, methods' successes and weaknesses were analyzed for possible use in the future.

\section{General Conclusions on the Urban Center Plaza}

Criticism of the plaza has changed over time, but seems to have always existed. This is in contrast to the abundance of people that use the plaza, undoubtedly including those who criticize it to some extent. When the plaza was only grey space, there were those who called it "barren" or "exposed", as was reported by the Capstone class. Now that it has green space in it as well, there are those who criticize the apparent American tendency to shy away from so-called empty space, and desire more "stuff" (in this case "green stuff"). Architects and 
casual observers have also criticized the green space as not working to its full capacity. The aspen trees are small and don't seem to flourish. The drainage containers never seem to fill to capacity to the point of overflowing via the spouts as was intended by the designers (Nevue Ngan, 2012). And then of course there is the removal of those eastern stairs. This prompts the critique that the green space is really "green washing". Now that the Recreation Center is constructed as well, the plaza almost seems to not get enough sunlight.

In addition, it seems that whatever stage the plaza is in, some sort of criticism surfaces as has been observed in the original design via the Capstone course's research and after the stormwater retrofit. This may be due to its high profile as the entryway to the new district of the university or its prominent location near services frequently used by many people (including transit stops, the bookstore, Recreation Center, and the nearby food options). It also stands out because it went through several stages of development which can increase the amount of criticism it can receive (as it has gone through four stages as opposed to what might be considered the usual one).

Based on the observations reported here, the Urban Center Plaza is actually a very successful space. Those interviewed also came to the same conclusion. As it was intended to (literally) pave the way for the eastern section of the campus, it has successfully been a part of the new development. The Recreation Center was constructed later and now draws many students to these high quality gym and classroom facilities. Transit lines create a hub of activity and connectivity for students and city residents alike. Nearby, a new apartment building was also 
constructed with more food options located on the ground floor, further drawing people towards the east and connecting city with university. Another new building, a sustainability center, is also being planned for the block to the southeast, which will surely increase the use of the plaza. Was it the plaza itself that spurred the development and use of the area? Not necessarily. But it definitely played a part in allowing for a public space for this section of the new University District master plan before the other buildings are completed.

Video observations also conclude that the space is used successfully overall. Though conflict still exists, as mentioned previously, no glaringly severe issues exist that make this space deficient in some way. The pedestrian counts, though influenced by the transit lines, still illustrate the large amount of people that use the plaza to some extent - one of the key indicators of a successful public space. Children and women are numerous, and during peak times, it may even be difficult to find a place to sit on the terraced seats. The near-constant flow of activity provides people to watch while eating lunch or taking advantage of good weather. The large upper terrace allows for events, neighborhood activities on the weekends, and enough room for multiple travel paths and modes of transportation. Seating options are numerous, allowing for shaded green space, relaxing water sounds, backed or backless seats, lounging, and lying down. As the area develops more as time goes on, the plaza may be more fully utilized as a social space for the university and city alike.

\section{Suggestions for Improvement}


Though the plaza seems to be successful, there are some points of conflict and room for improvement that vary in complexity, but should also be suggested for this space. Because the university owns the plaza, these suggestions are mostly directed towards that institution. However, creative solutions can possibly be taken on by specific offices, businesses, and colleges in the university nearby as well.

\section{Simple Solutions}

One of the constant issues and ideas is the lack of movable seating in the upper plaza. The Capstone course suggested adding these as well, specifically near the top ledge of the tiered seating. In this area in particular, little traffic moves through the space, so the flow would not be affected. This would also solve the issue of larger groups of people attempting to form a circle for conversation on the top ledge. Only a certain amount of people can sit side-by-side before it is difficult to talk with the person on the opposite end. Because of this, some people are forced to stand in order to carry out this conversation. By adding chairs that can be rearranged, they can bring them to the ledge and create their own comfortable environment. This can also provide more segregated seating for individuals who don't feel as though there is enough room between already seated individuals on the tiered steps. Movable chairs also give freedom for facing the sun while it is in the plaza. 


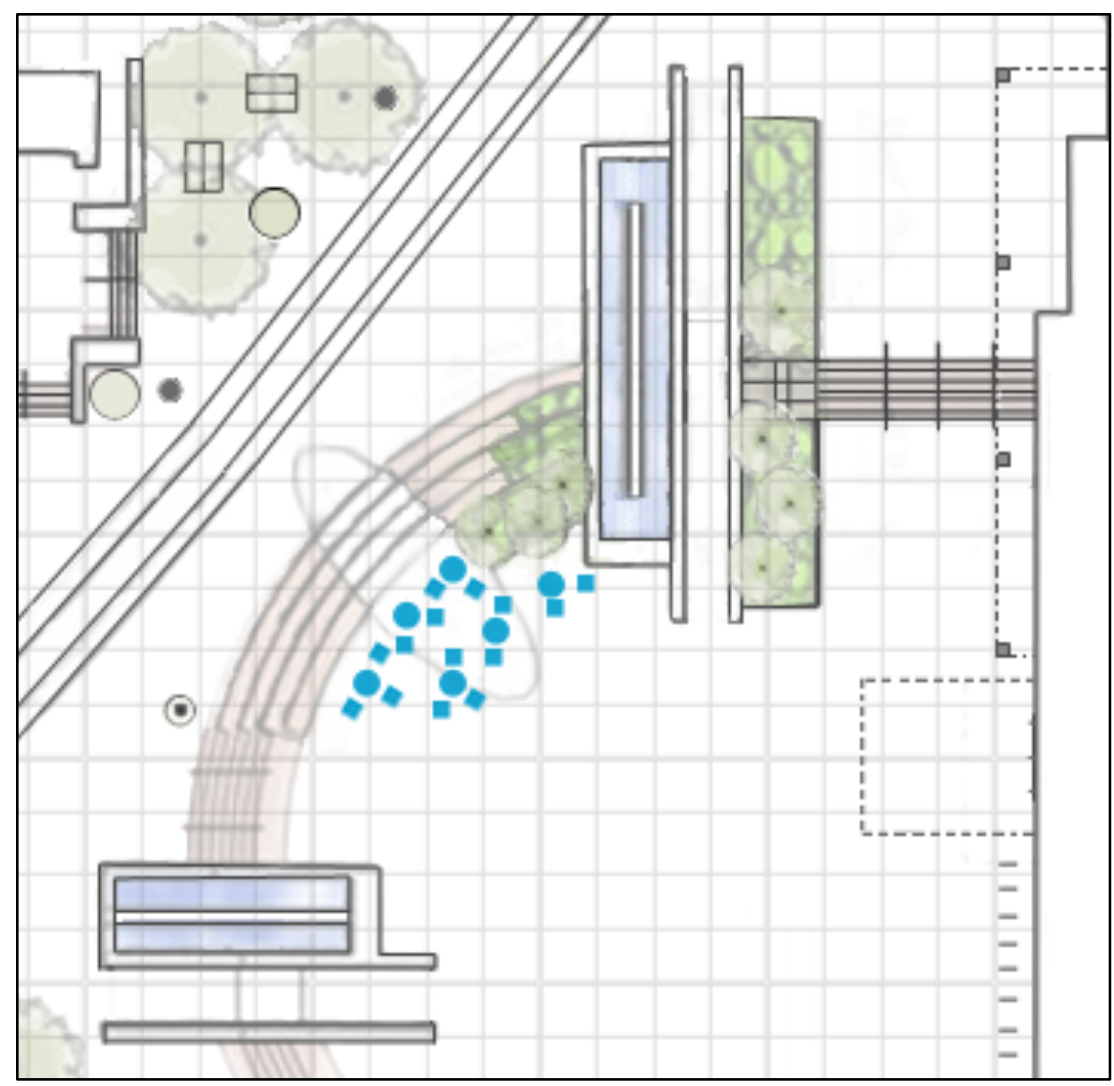

Figure 51: Possible suggested table and chair layout for upper plaza

In order to implement this, chairs would need to be purchased and managed in the space. However, the space is fairly small and so would not require many chairs, perhaps roughly 10-15 would do (see Figure 51). It may be suggested that chairs found in other excellent examples of movable seating, such as in Director Park here in Portland and Bryant Park in New York City, be placed here (see Figure 14 for example of chairs at Director Park). An office for student assistance is located inside the Recreation Center near the entrance, and has a direct view of the upper plaza out their window. This may be a convenient way to manage the chairs whereas this office could put them on the plaza and bring them inside at night while storing them nearby. This would also only have to be managed during the nicer 
months. If these chairs are successful, and because of the large number of people during the lunch hours, the addition of small, foldable or portable café tables to provide more options and space for activities is also recommended.

Another fairly simple solution would be to move the trashcan to the north of the upper plaza. Because of the forced flow of pedestrians towards the northern stairs, the trashcan provides an obstacle for the large number of people navigating the area in an attempt to reach the western side as fast as possible. A better location could be closer to the northern fountain, near the western side of that set of stairs, which is less frequently used than the right side or middle section. Another possibility would be to move it towards the eastern fountain instead, though this may not be as easy to use because of its less convenient location. An important point of consideration when altering this trashcan should be the abundance of trashcans in other locations closer to the building. No reason for why this particular location was chosen in the first place was uncovered, though, which may affect this suggestion.

Another suggestion for the space would be to allow more manipulability and access. If flyers are torn down from the metal poles by rule, they could be allowed in order to create a more interactional space. Instead of emphasizing the university's presence by only having flyers in the Urban Center building, this can possibly encourage more community involvement in the space or personal expression. As opposed to the designed space we see today, it could morph to a living space where certain aspects change, enhancing the public experience. If an event is to be held in the plaza, flyers could equally spread awareness of this upcoming event and 
increase attendance. This could also provide another connection to the university's more central core - the PSU Park Blocks a few blocks away. Here one can find notices posted in abundance providing information on upcoming events, classes, concerts, etc. For those now using the eastern side of the campus more than the traditional western side, it would only enhance the sharing of information and feeling of unity while simultaneously presenting it to the public as well. To implement this may mean a simple change in policy on the part of the individuals responsible for removing flyers, though it has not been discovered who specifically is in charge of this.

\section{Other Possible Improvements}

Some other options that are more complex involve design elements and the alteration of the plaza itself. This of course makes it less likely that they could be implemented; however again, including these suggestions based on the research, even if only to address the issues, is important. These would also have to be implemented by the university as the owner of the space, and would require the intervention on the part of (most likely) the previous designers of the plaza. Further, these are by no means necessary to improve the space, and may not even be possible given potential costs involved.

First and foremost, the reintroduction of stairs on the eastern side of the upper plaza would be very beneficial to the movement through the space. In this case it may even be possible to retain some of the green space, just add a single small set of standard steps by removing some of the drainage containers. This would 
be welcomed by many who feel frustrated at going out of their way to move across the plaza, and by those who used the plaza when it was only grey space. Obviously, however, it would be a significant undertaking at this point considering the drainage containers' depth, vegetation, etc. Realistically, an analysis of the efficiency of the drainage areas would be done beforehand, and should be carried out regardless. It should be taken as a serious concern, however, that as the university grows and more buildings are added to the eastern district of the campus, the travel from east to west might continue to increase over time.

A much more difficult alteration would be to widen the ramps on the eastern and western sides of the upper plaza. This is influenced by the width restrictions and wait times of bicyclists, people in wheelchairs, and walkers/runners, all attempting to use this route through the plaza at the same time. However, altering these areas would be nearly impossible on the eastern side with the green space and fountain on either side of the existing ramp. On the western side, the only feasible possibility would involve switching the ramp and adjacent stairs which are a more appropriate width (see Figure 26). Again, this is not necessary, but may become more of a concern if traffic increases in the future.

A final suggestion would be to add textured strips to the area along the streetcar tracks. Again, while no conflicts have seemed to occur involving the streetcar and pedestrians, even apparently amongst blind or deaf persons, this may still alleviate stress while moving through the space for people that depend on texture or visual cues. Small lights located along the track may be helpful, though 
costly. Obviously, consulting further with blind users of the plaza to more fully analyze the handicapped issues surrounding the space would be suggested.

As a further consideration, while the artwork, specifically the large granite sculptures, are probably never going to be moved (or simply cannot be moved), it may be beneficial to look more closely at the various points of congestion to the north of the streetcar tracks in the lower plaza. Specifically, the northwestern sculpture is very close to several tables and chairs for the pizza place nearby, as well as those waiting for the streetcar. Maneuvering through this space when it is full is difficult, especially for people on bicycles (who sometimes ride between the tracks avoiding the congestion). The sculpture near the entrance to the Urban Center building is now more of a concern due to the addition of a second row of bicycle racks and rearranging of benches on the side of the building. In regards to street furniture and other obstructions, the area nearest to the light rail stop to the east of the lower plaza is another difficult area to navigate, though mostly due to the need to travel further north to ascend the northern steps.

\section{Programming Improvements}

Opinions on the programming of space range from the strictest insistence that it be required for good public space, to those who feel the casual use of space by the public should be good enough. It seems then a balance is the best approach and the intent and use of the space should be taken into consideration. In a space like the Urban Center plaza, there are plenty of opportunities for sufficient activity most of the time. However, the plaza was planned in such a way that it could support large 
gatherings of people and balance (or even replace) the events on the western campus such as the Portland State farmer's market on the Park Blocks (Portland Development Commission, 1999). A few events are held here at present, like the welcome back to school event witnessed, but it seems to be the case more events previously took place on the plaza, like the graduation ceremony. While not every plaza needs to be relentlessly programmed, it could be beneficial to hold more events in this space to take full advantage of the capabilities of the plaza during the off-peak times, and to strive towards the goal of incorporating the plaza into the community as stated by the University (Portland Development Commission, 1999).

This may simply mean dividing the events between the two major public spaces of the university to a certain extent. Perhaps holding one of every five events appropriate for grey space in the plaza would further assist in bringing people to this area, for example. Another suggestion would be to encourage student activities in this place, or community events such as concerts on the weekends. It is possible, however that these events are now taking place more in the summer. While no obvious street performers were observed, this kind of behavior should be encouraged as well, especially during the lunch hours.

\section{Significance of Research}

When considering the significance of this research project, it is important to note that this type of research has been done before. However, each space should be considered within its own context and analyzed in regards to the human scale, individually assessed for design issues and suggestions as well. Though people tend 
to behave in similar ways to an extent, the shape of the urban landscape impacts patterns of movement and staying in space, and so needs to be closely examined in each circumstance.

The historical component to the process of the formation of space also needs to be researched in order to fully understand the place. Whyte provides a wonderful example of this when looking at seating options in New York City (Whyte 1990). When looking at ledges located near a bank, he discovered rocks and spikes protruding from them. Rather than regarding them a poor design decision or oddity, he looked into it and found that these features had been specifically added to the ledges by the businesses in an attempt to decisively keep people from sitting on them. With this knowledge in hand the critique then was on the control of public space by these private institutions and suggestions are to disallow this type of modification in the cityscape so that pedestrian usage is the priority.

In the Urban Center Plaza, knowing that the green space was not a part of the original design, for instance, or that stairs used to exist where now there are none, the critique can be placed more on the separate phases of development rather than the overall design that we see today. However, we were also armed with the knowledge that the light rail stop on the eastern edge was not necessarily going to be almost directly across from these missing steps when they were taken out. Given this, the critique can perhaps be placed more so on unforeseen circumstances and the underestimation of the pedestrian traffic that would sweep across the space from the east. Also, those who criticize the large empty space at the upper plaza may be unaware that it was intended to be used as a transitional space as well as large 
events. Knowing this, we can suggest perhaps more events to take full use of the space. Without this historic context and more in-depth research into the process, the analysis of the plaza would have been quite different and we now find critiques are at times misplaced.

In conducting the analysis of the plaza, a format has been created which can be copied in many other locations to assess their success. The mixed methods approach following Whyte's studies reveals quite a bit more about a space than just pedestrian counts or design critique alone. Being in the space, using it, and experiencing what the pedestrian sees, hears, and feels, provides a more intimate and accurate perspective. Watching people without them realizing it in real time allows you to assess the common behavior and travel patterns. Given enough time, generalizations can be formed that will help improve the space. If only one or two people conduct a particular behavior, it may not be significant enough to alter the landscape. But if dozens or hundreds of people conduct a similar activity over the course of two weeks, then it becomes a recognizable pattern which should be more closely examined. Even if that behavior is something a casual observer might note as well, having the quantitative evidence to support the qualitative observations makes a difference in the validity of the results.

Because of the process of urban design, in that a firm is hired for a project but is only involved during its design and construction, the company that designed it does not necessarily handle the later evaluation of the space. The land itself is owned by the client who is responsible for the product after the fact. If design alterations are noticed by the architects post-completion, they don't necessarily 
have the ability to alter the space anymore. Often, the company does not have the resources to conduct a thorough analysis of their completed work in the first place. Research like this can serve a dual function for the space and people involved. The designers more fully recognize how their design is used and possibly what they should or should not do in the future, and the owners are provided suggestions as to alterations they may make in order to have a more successful space. In some instances this may prove to be more crucial than is necessarily the case in the Urban Center Plaza. Some parks and plazas have problems with illegal behavior such as drug dealing or simply inactivity. While in this space this was not clearly the case, the methods can be used to reveal this type of challenge as well.

\section{Suggestions for Future Research}

After analysis of this space and assessment of the methods, there are some suggestions for alterations and limits regarding this project as well as suggestions for future research in this area. One of the most important is to analyze the effectiveness of the drainage basins in the upper plaza. While the author possesses neither the knowledge nor the equipment necessary to do so, this would be valuable in further assessing the success of the plaza, or for future alterations to the space. If the entire eastern drainage area were not needed, it would possibly then allow for a small set up stairs to be reintroduced into the space. This is also, again, a point of conflict for the plaza, and so might help to alleviate concerns or critiques.

Something else that could have been conducted would be a thorough replication of the sunlight effects on this space in conjunction with the seating 
patterns. While shade lines were recorded during the video observation process, a detailed pattern of sitting behavior in regards to the line of shade was not created. The Recreation Center fairly quickly casts a shadow over most of the space, including much of the tiered seats on the northern end. It was not obvious to me, however, that people decided to sit in the sun or shade more than the other. On one occasion it was very clear that a group of people sitting on the ledge of the northern fountain all changed location once the shade line moved to their position, but this was a rare event. On the other hand, during the warmer days of the summer, it might make more sense to sit in the shade more than the sun. This would require an analysis focused specifically on this type of behavior, however, and was outside the realm of this study. It could be theorized that Whyte's synopsis that people prefer choice more than just sun or shade alone, is more important. If this is the case, this space successfully allows for a variety of choice.

In conjunction with the sunlight analysis, a seasonal comparison may have been helpful as well. While the first week was warmer than the second, activity was higher during the second week due to classes being in session. This prevents a thorough analysis as to how temperature and cloud cover affect sitting and general behavior. It may be that the temperature during the time of the observation was also conducive to casual staying behavior, more than it may be during the spring and peak summer months, and definitely more than the winter when Portland is fairly wet and cold most of the time. A two-week study during each major season may provide more of a comparison for behavior in the plaza. 
Another comparison that may have been helpful would be to also conduct an analysis on a park or plaza elsewhere in Portland for a comparative context. For instance, the Park Blocks at Portland State would be a good counterpoint for study considering they are referred to as the heart of the campus, are a very different kind of space, but are close to the Urban Center Plaza (see Figure 52). Brief observations there reveal a wider range of activities due to the size of the space, the less transitional nature, and natural features of grass and large shady trees. People lie on the ground to relax or read, practice tricks with larger objects because of the available space, and attend more events like the farmer's market. Researching how this space is used in conjunction with the Urban Center Plaza may be informative as to how to balance the two different types of spaces, for instance.

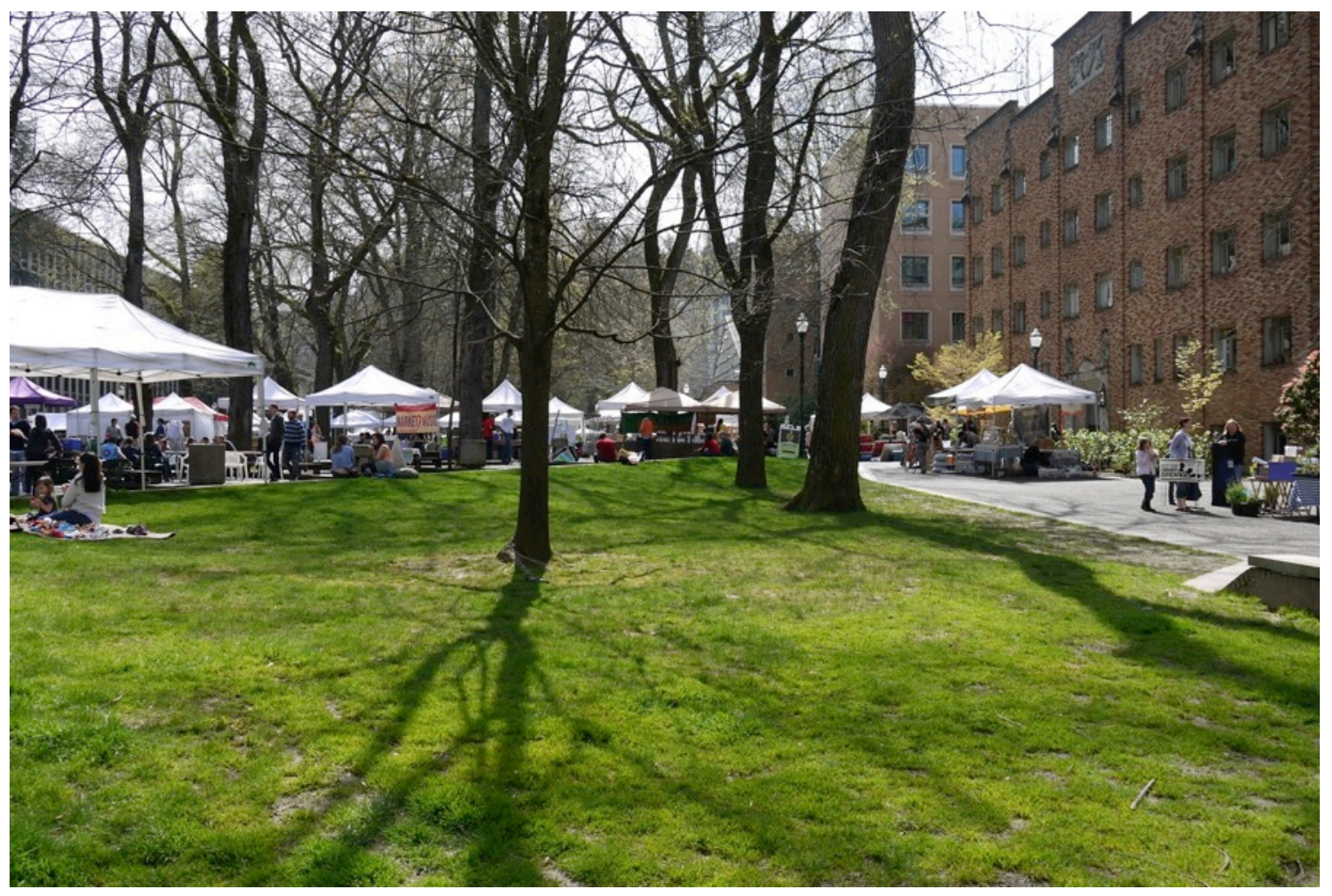

Figure 52: PSU Farmer's Market at the Park Blocks west of the Urban Center Plaza (photo by author, 2012) 
A more controversial suggestion could be research into the allowance of skateboarding in this space. This of course is more controversial as it would be affecting the only officially stated prohibited behavior in the plaza. While it is true that skateboarders may impact the structures of the space, preventative measures have been taken, and most of the uses in the plaza that were witnessed were not the damaging "grinding" behavior. It is interesting that skateboarders were in this space, despite the stated rule and presence of police officers. On a few occasions skateboarding activity took place while an officer's vehicle was in the plaza nearby. There is a further possibility that because the skateboarders tend to use the plaza in off-peak hours, they may even assist in the eyes-on-the-street concept of safety and be beneficial to the place. If it is the case that skateboarding will happen regardless, it stands to reason that this subject may need more investigation. A related analysis may be a more detailed study of homeless populations in particular in the plaza as well.

\section{Project Limitations}

In regards to the methods component of this research, a few aspects of the observations could have been changed. Originally, the hours and days observed were completely randomized to provide true experimental observation to the space. Unfortunately, a few hours were not observed thoroughly enough to definitively state their tendencies, and one hour in the second week was never observed at all. This allows one to generalize the overall findings, but not conduct thorough statistical analyses as easily. 
If this thesis were to be conducted over again, the research design would be altered to observe every day of the week and alternate every other day with an every other hour observation schedule within the previously selected times. Now that it is also know the lunch hours are the highest for sitting and travel behavior, that section would be observed continuously. This way, every hour would be observed an equal number of times and have a more regular data set for analysis. The days could also have been broken up into half hour increments, as in 1:30 PM 2:30 PM instead, since Whyte's results showed 12:30 PM - 1:30 PM to be the peak times for lunch traffic. It was organized it in such a way to have a more regular set of intervals that were easier to track. Now that it's clear that 1:00 PM to 2:00 PM seem to have the most sitting behavior, this may in reality be due to the 1:00 PM - 1:30 PM lunch crowd continuing their behavior from the 12:30 PM time period. A further analysis of this could have been conducted if both hours were consistently observed every day. Further, given a team of assistants or more time (such as Whyte had) the author would simply observe every hour for several weeks, including the seasonal comparisons. This could also track the time spent in the space more thoroughly. Rather than just notes and mapping locations, a chart of time spent by each person or group that was sitting or pausing could be constructed.

Perhaps most importantly, to assess the impact of the plaza on the community, as a stated goal of the space, surveys could have been distributed to the surrounding area to see more accurately who goes there and why. This information would provide more context as to what people would like to see this plaza used for, though that was not the primary focus or point of concern when conducting this 
study. This is something that the university could also simply begin doing in the form of formal and casual events in order to see how popular it becomes. During the large event for the beginning of the school year on September $26^{\text {th }}$, the highest number of sit events for the entire observation period were recorded at 117 between the hour of 1:00 PM and 2:00 PM. Observations showed this was directly related to the events taking place on the plaza during that time. However, also knowing what nearby residents think could improve their experience as well. A possible flaw in this data regards the visibility issues of the recording location and angle. The tree on the left side of the camera's visibility did obstruct some activity, though most was still able to be recorded due to secondary movement of people (i.e. an individual clearly standing up from a low-visibility seating location). Another area of concern was the northern side of the western tiered seats near the trashcan. Again, people were only viewed either partially or as they sat down or stood up, but not necessarily direct and accurate behavior. Because of this, there was less focus on analyzing this section of the plaza. Also, regardless of possible error, this area did not seem to be as popular as the northern tiered seats. It is suggested that this is due to a lack of visibility towards the streetcar and restaurants, as well as its more frequent use as part of the travel route. It was however used more frequently for activities (such as the soccer ball practice and skateboard jumps mentioned previously). This particular camera angle was the most convenient for the hours observed in terms of accessibility and consistency, though, and it seems none of this significantly impacted the results. Video 
observations of the western section and the northern area of the plaza could be carried out with a different angle in the future to complete this analysis if needed.

Finally, there was the issue of the Capstone Course's research data. While informative, the limitations of their research did not provide as much of a comparison in the space as was previously thought. Because of the difference in video recording types, it was impossible to directly compare them accurately for patterns in behavior. Their emphasis on surveys also did not provide an accurate comparison because of the alteration to the research design, and their limited time for observations were not as thorough as this project's. They provided a basis for some very basic comparison and context regarding the phase of development they studied, but little else in their short report.

\section{Final Thoughts}

By researching this plaza the author was able to obtain certain skills and experiences that lend a greater amount of insight into the plaza's function, design, and overall character. This project shows that despite potential criticism, many more people appear to use the plaza than could be estimated through casual observation. The space is very unique, used in a variety of ways, and compliments the university nicely. It is also a good addition to Portland's many plazas, overall, because of its popularity and lack of overt negative behavior.

It also shows the need for this kind of constant evaluation of places in an urban environment. As cities change around a constructed space, that space may need to be analyzed for further alteration or programming. Cataloguing successful 
elements in space can also be beneficial for the architects involved who go on to create other spaces. As Whyte discussed, sharing this knowledge is beneficial not only to the users of the space, but to the cities and designers who would otherwise be forced to deal with derelict spaces later. As time passes, renewed research into the complex elements is still needed in order to benefit the contemporary city in its current context.

It is possible a more complex plaza or park would have been a more appropriate target for this study. However, because this is the author's first official experience in this type of research project, it is most likely fortuitous that the plaza presented a pleasantly blank canvas with which to study. Rather than assess complicated actions such as drug dealing or a stark lack of people in general, the author was able to focus on (what was viewed as virtually harmless) skateboarders or fathers doting on their children. While a more challenging situation will surely present itself in the future, this experience was a beneficial project methodologically, adds to the academic literature on the subject, and hopefully is helpful for the community at large as well. 


\section{Works Cited}

Abramson, D. B. (2007). The dialectics of urban planning in China. In F. Wu (Ed.), China's emerging cities: the making of new urbanism (Vol. 26). London:

Routledge.

Al-hagla, K. (2008). Towards a sustainable neighborhood: the role of open spaces. International Journal of Architectural Research, 2 (2), 162-177.

Andersson, T. (2008). Swedish Mid-Century Utopia: Park Design as a Tool for Societal Improvements. In M. Conan \& C. Wangheng (Eds.), Gardens, City Life and Culture: A World Tour (pp. 157-172). Washington D.C.: Harvard University Press.

Bianca, S. (2000). Urban form in the Arab world: past and present (p. 347, [1]). London; New York: Thames \& Hudson.

Blank, S., Dodson, E., Farnen, H., Harrasser, S., Kido, J., \& Sanguinetti, M. (2004). City Repair, The Urban Plaza, and Public Spaces (p. 30). Portland, OR.

Briggs, X. D. S. (2004). Civilization in Color: The Multicultural City in Three Millennia. City \& Community, 3(4), 311-342.

Carmona, M. (2010a). Contemporary Public Space, Part Two: Classification. Journal of Urban Design, 15(2), 157-173.

Carmona, M. (2010b). Contemporary Public Space: Critique and Classification, Part One: Critique. Journal of Urban Design, 15(1), 123-148. doi:10.1080/13574800903435651

Carmona, M., Magalhaes, C. D., \& Hammond, L. (2008). Public Space: The Management Dimension. London, New York: Routledge.

Carr, S., Francis, M., Rivlin, L. G., \& Stone, A. M. (1992). Public Space. Cambridge: Cambridge University Press.

Castillo, G. (1994). Gorki Street and the Design of the Stalin Revolution. Streets: Critical Perspectives on Public Space (pp. 57-70). Berkeley, California: University of California Press. 
Duany, A., Plater-Zyberk, E., \& Speck, J. (2001). Suburban Nation: The Rise of Sprawl and the Decline of the American Dream (1st ed., p. 294). New York: North Point Press.

Francis, Mark. (2003). Urban Open Space: Designing for User Needs (p. 85). Washington D.C.: Island Press.

Fusch, R. (1994). The Piazza in Italian Urban Morphology. Geographical Review, 84(4), 424-438.

Gehl, J. (2010). Cities for People (p. 269). Washington D.C.: Island Press.

Hajer, M., \& Reijndorp, A. (2001). In Search of New Public Domain. Rotterdam: NAI.

Harding, V. (2004). Recent Perspectives on Early Modern London. Historical Journal, 47, 435-450. Retrieved from http://search.ebscohost.com/login.aspx?direct=true $\& d b=a p h \& A N=13759467$ \&site=ehost-live

Hou, J. (Ed.). (2010). Insurgent Public Space: Guerilla Urbanism and the Remaking of Contemporary Cities (p. 276). London and New York: Routledge.

Jacobs, J. (1961). The Death and Life of Great American Cities (3rd ed., p. 598). New York: Random House.

Jashemski, W. (2008). Gardens and Garden Life in Pompeii in the First Century A.D. In M. Conan \& C. Wangheng (Eds.), Gardens, City Life and Culture: A World Tour (pp. 15-28). Washington D.C.

Kent, F. (2012). Project for Public Spaces - Bryant Park. Retrieved March 16, 2012, from http://www.pps.org/projects/bryantpark/

Krier, L. (2009). The Architecture of Community. (D. A. Thadani \& P. J. Hetzel, Eds.). Washington, Covelo, London: Island Press.

Lees, L. H. (1994). Urban Public Space and Imagined Communities in the 1980s and 1990s. Journal of Urban History, 20(4), 443-465.

Levy, R. I. (1990). Mesocosm: Hinduism and the Organization of a Traditional Newar City in Nepal. (pp. 221). Berkeley: University of California Press.

Low, S. M. (1993). Cultural Meaning of the Plaza: The History of the SpanishAmerican Gridplan-Plaza Urban Design. In G. W. McDonogh \& R. L. Rotenberg (Eds.), The Cultural Meaning of Urban Space (pp. 75-93). Westport, Conn.: Bergin and Garvey. 
Low, S. M. (2000). On the Plaza: The Politics of Public Space and Culture (p. 274). University of Texas Press.

Low, S. M., \& Smith, N. (2006). The Politics of Public Space (p. 185). New York: Routledge.

Ma, L. J. C., \& Wu, F. (2005). Restructuring the Chinese city: changing society, economy and space. (p. 283). London; New York: Routledge. Retrieved from http://www.loc.gov/catdir/toc/ ecip0417/2004009694.html

Macy, D. (2012). Interview.

Madanipour, A. (2003). Public And Private Spaces Of The City. New York: Routledge.

Marcuse, P. (2011). Occupy and the Provision of Public Space: The City's Responibiities | Peter Marcuse's Blog. Retrieved December 9, 2011, from http://pmarcuse.wordpress.com/2011/12/01/occupy-and-the-provision-ofpublic-space-the-citys-responsibility/

Mehta, V. (2008). Walkable streets: pedestrian behavior, perceptions and attitudes. Journal of Urbanism: International Research on Placemaking and Urban Sustainability, 1(3), 217-245. doi:10.1080/17549170802529480

Mitchell, D. (2003). The right to the city: Social justice and the fight for public space. New York: Guilford Press.

Molotch, H., \& Noren, L. (Eds.). (2010). Toilet: Public Restrooms and the Politics of Sharing (p. 316). New York and London: New York University Press.

National Weather Service - NWS Portland. (2012). Retrieved March 25, 2012, from http://www.nws.noaa.gov/climate/xmacis.php?wfo=pqr

Nemeth, J. (2009). Defining a Public: The Management of Privately Owned Public Space. Urban Studies, 46(11), 2463-2490. doi:10.1177/0042098009342903

Nevue Ngan. (2012). Interview.

OLIN: blog. (2012). Retrieved March 4, 2012, from http://www.theolinstudio.com/

Orloff, C. (2004). If Zealously Promoted by All: The Push and Pull of Portland Parks History. In C. P. Ozawa (Ed.), The Portland Edge: Challenges and Successes in Growing Communities (p. 321). Washington D.C.: Island Press.

Owens, E. J. (1991). The City in the Greek and Roman World (p. 210). London and New York: Routledge. 
Ozawa, C. P. (Ed.). (2004). The Portland Edge (p. 321). Washington D.C.: Island Press.

Portland Development Commission. (1999). University Plaza The Urban Center. Development (p. 2). Portland, OR.

Portland Parks \& Recreation :: Simon \& Helen Director Park. (2012). Retrieved March 11, 2011, from http://www.portlandonline.com/parks/finder/index.cfm?PropertyID=1335\&a ction=ViewPark

Project for Public Spaces - Placemaking for Communities. (2011). Retrieved January 12, 2010, from http://www.pps.org/

Reynolds, F. (2011). After Zuccotti Park: Seven Privately Owned Public Spaces to Occupy Next | The Nation. Retrieved March 3, 2012, from http://www.thenation.com/article/164002/after-zuccotti-park-sevenprivately-owned-public-spaces-occupy-next

Richardson, M. (1982). Being-in-the-Market versus Being-in-the-Plaza: Material Culture and the Construction of Social Reality in Spanish America. American Ethnologist, 9(2), 421-436.

Sennett, R. (1990). The Conscience of the Eye: The Design and Social Life of Cities (p. 266). New York: Knopf.

Shwartz, T. (2010). United Cerebral Palsy of Oregon and Southwest Washington Annual Report 2010 (p. 15).

Sitte, C. (1889). The Art of Building Cities (English Tr., p. 127). New York City: Reinhold Publishing Corporation.

Smith, M. E. (2002). The Earliest Cities. In G. Gmelch \& W. P. Zenner (Eds.), Urban Life Readings in the Anthropology of the City (4th ed., pp. 3-19). Prospect Heights, Illinois: Waveland Press, Inc.

Smithsimon, G. (2008). Dispersing the Crowd: Bonus Plazas and the Creation of Public Space. Urban Affairs Review, 43(3), 325-351. doi:10.1177/1078087407306325

Stanley, B., Stark, B. L., Johnston, K., \& Smith, M. E. (accepted for publication). Urban Open Spaces in Historical Perspective: A Transdisciplinary Typology and Analysis.

Tiesdell, S., \& Varna, G. (2010). Assessing the Publicness of Public Space: The Star Model of Publicness. Journal of Urban Design, 15(4), 575-598. 
Toulan, N. A. (2012). Interview.

Urban Center Plaza Stormwater Retrofit | Nevue Ngan Associates. (2011). Retrieved March 16, 2012, from http://nevuengan.com/green-infrastructure/urbancenter-plaza-stormwater-retrofit

Walker Macy :: PSU Urban Center Plaza. (2012). Retrieved March 5, 2012, from http://www.walkermacy.com/projects/urban_design_and_plazas/psu_urban_c enter_plaza/03/

Ward-Perkins, J. B. (1974). Cities of Ancient Greece and Italy: Planning in Classical Antiquity. (G. R. Collins, Ed.) (p. 128). New York: George Braziller Inc.

Weissman, R. F. E. (1982). Ritual Brotherhood in Renaissance Florence. New York: Acadamic Press.

Whyte, W. H. (1980). The Social Life of Small Urban Spaces (p. 125). Washington D.C.: The Conservation Foundation.

Whyte, W. H. (1990). City: Rediscovering the Center (p. 386). New York: Anchor Books.

Wycherley, R. E. (1976). How the Greeks Built Cities (2nd ed., p. 235). New York, London: W. W. Norton \& Company.

Zucker, P. (1959). Town and Square: From the Agora to Village Green. New York: Columbia University Press. 


\section{Appendix A: Randomized Video Observation Schedule}

\section{Week 1: September 18 - September 242011}

\begin{tabular}{|l|l|l|l|l|l|l|}
\hline Time & Monday & Tuesday & Wednesday & Thursday & Friday & Saturday \\
\hline 9:00 am - 10:00 am & & & & & & \\
\hline 10:00 am - 11:00 am & & & & & & \\
\hline 11:00 am - 12:00 pm & & & & & & \\
\hline 12:00 pm - 1:00 pm & & & & & & \\
\hline 1:00 pm - 2:00 pm & & & & & & \\
\hline 2:00 pm - 3:00 pm & & & & & & \\
\hline 3:00 pm - 4:00 pm & & & & & & \\
\hline 4:00 pm - 5:00 pm & & & & & & \\
\hline $5: 00 \mathrm{pm}-6: 00 \mathrm{pm}$ & & & & & & \\
\hline $6: 00 \mathrm{pm}-7: 00 \mathrm{pm}$ & & & & & & \\
\hline
\end{tabular}

Week 2: September 25 - October 12011

\begin{tabular}{|l|l|l|l|l|l|l|}
\hline Time & Monday & Tuesday & Wednesday & Thursday & Friday & Saturday \\
\hline 9:00 am - 10:00 am & & & & & & \\
\hline 10:00 am - 11:00 am & & & & & & \\
\hline 11:00 am - 12:00 pm & & & & & & \\
\hline 12:00 pm - 1:00 pm & & & & & & \\
\hline 1:00 pm - 2:00 pm & & & & & & \\
\hline $2: 00 \mathrm{pm}-3: 00 \mathrm{pm}$ & & & & & & \\
\hline $3: 00 \mathrm{pm}-4: 00 \mathrm{pm}$ & & & & & & \\
\hline 4:00 pm - 5:00 pm & & & & & & \\
\hline $5: 00 \mathrm{pm}-6: 00 \mathrm{pm}$ & & & & & & \\
\hline $6: 00 \mathrm{pm}-7: 00 \mathrm{pm}$ & & & & & & \\
\hline
\end{tabular}


Appendix B: Notification of Video Observation

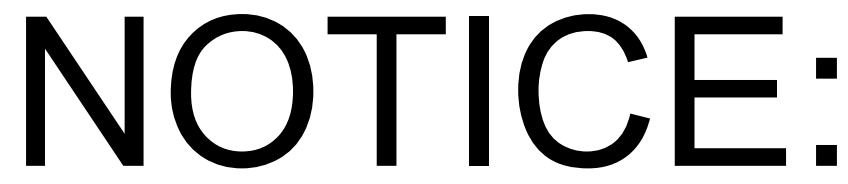

\section{THE URBAN PLAZA WILL BE \\ VIDEO RECORDED TODAY FOR \\ A PSU MASTERS STUDENT'S \\ THESIS RESEARCH PROJECT \\ AT RANDOM TIMES BETWEEN 8:00 AM AND 8:00 PM.}

This video will not be made public in any way and you will not be recognizable.

Any potentially identifiable information will be confidential.

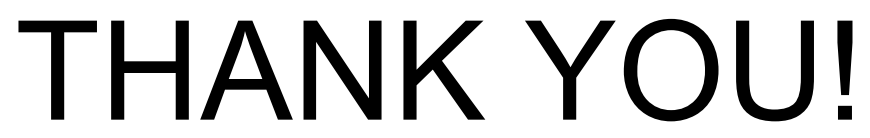




\section{Appendix C: Video File Records and Times}

\begin{tabular}{|c|c|c|c|c|}
\hline DATE & VIDEO & ACTUAL TIME & ASSIGNED TIME & COUNTS \\
\hline $\begin{array}{l}\text { Monday } \\
\text { September } 19\end{array}$ & 370 & $10: 01-11: 00 \mathrm{AM}$ & 10:00-11:00 AM & 856 \\
\hline \multirow[t]{9}{*}{ Day 1} & 371 & $11: 02-11: 15$ AM & & Extra Event \\
\hline & 372 & 11:16 - 12:01 AM & & Extra Event \\
\hline & 373 & $12: 12-12: 47$ AM & & Extra Event \\
\hline & 374 & 12:47 - 1: 47 PM & 1:00-4:00 PM & (Event) \\
\hline & 375 & 1:48 - 2:40 PM & 1:00 - 4:00 PM & 1345 (Event) \\
\hline & 376 & $2: 41$ - 3:39 PM & 1:00 - 4:00 PM & 893 \\
\hline & 377 & $3: 39-4: 04$ PM & 1:00 - 4:00 PM & 847 \\
\hline & 378 & 5:00 - 5:44 PM & 5:00 - 6:00 PM & - \\
\hline & 379 & 5:44 - 5:50 PM & 5:00 - 6:00 PM & 463 \\
\hline $\begin{array}{l}\text { Tuesday } \\
\text { September } 20\end{array}$ & 382 & 9:57 - 10:57 AM & $10: 00-11: 00 \mathrm{AM}$ & - \\
\hline \multirow[t]{6}{*}{ Day 2} & 383 & 10:57 - 11:03 AM & 10:00 - 11:00 AM & 563 \\
\hline & 384 & 11:59 - 12:59 PM & 12:00 - 1:00 PM & 936 \\
\hline & 385 & 1:59 - 2:59 PM & 2:00 - 5:00 PM & 777 \\
\hline & 386 & $2: 59$ - 3:08 PM & 2:00 - 5:00 PM & - \\
\hline & 387 & 3:09 - 3:59 PM & $2: 00-5: 00 \mathrm{PM}$ & 814 \\
\hline & 388 & 3:59 - 4:59 PM & $2: 00-5: 00 \mathrm{PM}$ & 717 \\
\hline $\begin{array}{l}\text { Wednesday } \\
\text { September } 21 \\
\end{array}$ & 389 & 9:59 - 11:00 AM & 10:00 - 12:00 PM & 812 \\
\hline \multirow[t]{10}{*}{ Day 3} & 390 & 11:00 - 12:00 PM & 10:00 - 12:00 PM & 719 \\
\hline & 392 & 12:59 - 1:25 PM & 1:00 - 2:00 PM & - \\
\hline & 393 & $1: 25$ - 1:50 PM & 1:00 - 2:00 PM & - \\
\hline & 394 & $1: 50$ - 1:59 PM & 1:00 - 2:00 PM & 909 \\
\hline & 395 & $2: 59-3: 23$ PM & $3: 00-4: 00 \mathrm{PM}$ & - \\
\hline & 396 & $3: 23-3: 47$ PM & $3: 00-4: 00 \mathrm{PM}$ & - \\
\hline & 397 & $3: 47$ - 3:59 PM & $3: 00-4: 00 \mathrm{PM}$ & 934 \\
\hline & 398 & $4: 54-5: 14 \mathrm{PM}$ & 5:00 - 6:00 PM & - \\
\hline & 399 & 5:15 - 5:35 PM & 5:00 - 6:00 PM & - \\
\hline & 400 & 5:36 - 6:00 PM & 5:00 - 6:00 PM & 673 \\
\hline $\begin{array}{l}\text { Friday } \\
\text { September } 23\end{array}$ & 401 & $9: 57$ - 10:19 AM & 10:00 - 11:00 AM & - \\
\hline \multirow[t]{3}{*}{ Day 4} & 402 & 10:19 - 10:41 AM & 10:00 - 11:00 AM & - \\
\hline & 403 & 10:41 - 11:01 AM & 10:00 - 11:00 AM & 591 \\
\hline & 406 & $11: 57-12: 20 \mathrm{PM}$ & $12: 00-3: 00 \mathrm{PM}$ & - \\
\hline
\end{tabular}




\begin{tabular}{|c|c|c|c|c|}
\hline & 407 & $12: 20$ - 12:42 PM & $12: 00-3: 00 \mathrm{PM}$ & - \\
\hline & 408 & 12:43 - 1:06 PM & 12:00 - 3:00 PM & 1134 \\
\hline & 409 & $1: 06-1: 26$ PM & 12:00 - 3:00 PM & - \\
\hline & 410 & $1: 28-1: 51 \mathrm{PM}$ & $12: 00-3: 00 \mathrm{PM}$ & - \\
\hline & 411 & 1:51 - 2:13 PM & 12:00 - 3:00 PM & 1157 \\
\hline & 412 & $2: 13-2: 34$ PM & 12:00 - 3:00 PM & - \\
\hline & 413 & $2: 35-2: 46$ PM & 12:00 - 3:00 PM & - \\
\hline & 414 & $2: 46-2: 47$ PM & $12: 00-3: 00 \mathrm{PM}$ & - \\
\hline & 415 & $2: 47-3: 00$ PM & 12:00 - 3:00 PM & 1071 \\
\hline & 416 & $4: 57$ - 5:18 PM & $5: 00-6: 00 \mathrm{PM}$ & - \\
\hline & 417 & $5: 18-5: 39$ PM & $5: 00-6: 00 \mathrm{PM}$ & - \\
\hline & 418 & $5: 39-6: 00 \mathrm{PM}$ & $5: 00-6: 00 \mathrm{PM}$ & 745 \\
\hline $\begin{array}{l}\text { Saturday } \\
\text { September } 24\end{array}$ & 419 & 9:04 - 9:27 AM & 9:00 - 10:00 AM & - \\
\hline \multirow[t]{14}{*}{ Day 5} & 420 & 9:28 - 9:48 AM & 9:00 - 10:00 AM & - \\
\hline & 421 & 9:48 - 10:03 AM & 9:00 - 10:00 AM & 342 \\
\hline & 423 & 11:57 - 12:18 PM & 12:00 - 1:00 PM & - \\
\hline & 424 & 12:19 - 12:38 PM & $12: 00-1: 00 \mathrm{PM}$ & - \\
\hline & 425 & 12:39 - 12:59 PM & 12:00 - 1:00 PM & 729 \\
\hline & 426 & $2: 00-2: 22$ PM & $2: 00-3: 00 \mathrm{PM}$ & - \\
\hline & 427 & $2: 23-2: 44$ PM & $2: 00-3: 00$ PM & - \\
\hline & 428 & $2: 45-2: 59$ PM & $2: 00-3: 00$ PM & 721 \\
\hline & 429 & $3: 57-4: 17$ PM & $4: 00-5: 00$ PM & - \\
\hline & 430 & $4: 18-4: 44$ PM & $4: 00-5: 00$ PM & - \\
\hline & 431 & $4: 45$ - 5:00 PM & $4: 00-5: 00 \mathrm{PM}$ & 417 \\
\hline & 432 & $5: 58-6: 20 \mathrm{PM}$ & $6: 00-7: 00$ PM & - \\
\hline & 433 & $6: 21$ - 6:39 PM & $6: 00-7: 00$ PM & - \\
\hline & 434 & $6: 40-6: 58$ PM & $6: 00-7: 00$ PM & 246 \\
\hline $\begin{array}{l}\text { Monday } \\
\text { September } 26\end{array}$ & 435 & $8: 48$ - 9:21 AM & 9:00 - 12:00 PM & - \\
\hline \multirow[t]{9}{*}{ Day 6} & 436 & $9: 22-9: 43$ AM & 9:00 - 12:00 PM & - \\
\hline & 437 & 9:53 - 10:15 AM & 9:00 - 12:00 PM & 1339 \\
\hline & $437(2)$ & $10: 16$ - 10:35 AM & 9:00 - 12:00 PM & - \\
\hline & 438 & $10: 35-10: 57 \mathrm{AM}$ & 9:00 - 12:00 PM & - \\
\hline & 439 & $10: 58-11: 18 \mathrm{AM}$ & 9:00 - 12:00 PM & 1792 \\
\hline & 440 & $11: 18-11: 39 \mathrm{AM}$ & 9:00 - 12:00 PM & - \\
\hline & 441 & $11: 39$ - 12:00 PM & 9:00 - 12:00 PM & 2600 \\
\hline & 442 & 12:57 - 1:19 PM & 1:00 - 2:00 PM & - \\
\hline & 443 & $1: 19$ - 1:39 PM & 1:00 - 2:00 PM & - \\
\hline
\end{tabular}




\begin{tabular}{|c|c|c|c|c|}
\hline & 444 & 1:39 - 1:59 PM & 1:00 - 2:00 PM & 2455 \\
\hline & 445 & $4: 57$ - 5:17 PM & $5: 00-6: 00 \mathrm{PM}$ & - \\
\hline & 446 & $5: 17-5: 41 \mathrm{PM}$ & $5: 00-6: 00 \mathrm{PM}$ & - \\
\hline & 447 & $5: 41-5: 59 \mathrm{PM}$ & $5: 00-6: 00 \mathrm{PM}$ & 1554 \\
\hline $\begin{array}{l}\text { Tuesday } \\
\text { September } 27\end{array}$ & 448 & $8: 59$ - 9:18 AM & 9:00 - 1:00 PM & - \\
\hline \multirow[t]{15}{*}{ Day 7} & 449 & 9:18 - 9:39AM & 9:00 - 1:00 PM & - \\
\hline & 450 & 9:39 - 10:03 AM & 9:00 - 1:00 PM & 1800 \\
\hline & 451 & $10: 03-10: 27 \mathrm{AM}$ & 9:00 - 1:00 PM & - \\
\hline & 452 & $10: 27-10: 48 \mathrm{AM}$ & $9: 00-1: 00$ PM & - \\
\hline & 453 & $10: 48$ - 11:08 AM & 9:00 - 1:00 PM & 1245 \\
\hline & 454 & $11: 08-11: 16 \mathrm{AM}$ & 9:00 - 1:00 PM & - \\
\hline & 455 & $11: 16-11: 38 \mathrm{AM}$ & $9: 00-1: 00$ PM & - \\
\hline & 456 & $11: 38-11: 59$ AM & $9: 00-1: 00$ PM & 1890 \\
\hline & 457 & 11:59 - 12:19 PM & 9:00 - 1:00 PM & - \\
\hline & 458 & 12:19 - 12:30 PM & $9: 00-1: 00 \mathrm{PM}$ & - \\
\hline & 459 & $12: 30$ - 12:52 PM & 9:00 - 1:00 PM & - \\
\hline & 460 & 12:52 - 12:59 PM & 9:00 - 1:00 PM & 1489 \\
\hline & 461 & $4: 58$ - 5:19 PM & $5: 00-6: 00 \mathrm{PM}$ & - \\
\hline & 462 & 5:19 -5:41 PM & $5: 00-6: 00 \mathrm{PM}$ & - \\
\hline & 463 & 5:41 - 5:59 PM & $5: 00-6: 00$ PM & 1415 \\
\hline $\begin{array}{l}\text { Thursday } \\
\text { September } 29\end{array}$ & 464 & $10: 58-11: 19$ AM & 11:00 - 4:00 PM & - \\
\hline \multirow[t]{16}{*}{ Day 8} & 465 & $11: 19-11: 39 \mathrm{AM}$ & 11:00 - 4:00 PM & - \\
\hline & 466 & $11: 39-11: 59 \mathrm{AM}$ & 11:00 - 4:00 PM & 2109 \\
\hline & 467 & 11:59 - 12:20 PM & 11:00 - 4:00 PM & - \\
\hline & 468 & 12:20 - 12:41 PM & 11:00 - 4:00 PM & - \\
\hline & 469 & 12:41 - 1:03 PM & 11:00 - 4:00 PM & 1861 \\
\hline & 470 & 1:04 - 1:24 PM & 11:00 - 4:00 PM & - \\
\hline & 471 & $1: 24-1: 43$ PM & 11:00 - 4:00 PM & - \\
\hline & 472 & $1: 43-1: 44$ PM & 11:00 - 4:00 PM & - \\
\hline & 473 & $1: 44-2: 10 \mathrm{PM}$ & 11:00 - 4:00 PM & 2110 \\
\hline & 474 & $2: 11$ - 2:19 PM & 11:00 - 4:00 PM & - \\
\hline & 475 & $2: 19-2: 28$ PM & 11:00 - 4:00 PM & - \\
\hline & 476 & $2: 28-2: 51$ PM & 11:00 - 4:00 PM & - \\
\hline & 477 & $2: 51-3: 10 \mathrm{PM}$ & 11:00 - 4:00 PM & 1384 \\
\hline & 478 & $3: 11$ - 3:30 PM & 11:00 - 4:00 PM & - \\
\hline & 479 & $3: 30-3: 46$ PM & 11:00 - 4:00 PM & - \\
\hline & 480 & $3: 46-3: 59$ PM & 11:00 - 4:00 PM & 1683 \\
\hline
\end{tabular}




\begin{tabular}{|c|c|c|c|c|}
\hline $\begin{array}{l}\text { Friday } \\
\text { September } 30\end{array}$ & 482 & 9:58 - 10:08 AM & 10:00 - 12:00 PM & - \\
\hline \multirow[t]{16}{*}{ Day 9} & 483 & $10: 08-10: 59 \mathrm{AM}$ & 10:00 - 12:00 PM & 1080 \\
\hline & 484 & $11: 00-11: 20 \mathrm{AM}$ & 10:00 - 12:00 PM & - \\
\hline & 485 & $11: 20-11: 30 \mathrm{AM}$ & 10:00 - 12:00 PM & - \\
\hline & 486 & $11: 30-11: 31 \mathrm{AM}$ & $10: 00-12: 00 \mathrm{PM}$ & - \\
\hline & 487 & 11:31 - 11:52 AM & 10:00 - 12:00 PM & - \\
\hline & 488 & 11:52 - 12:00 PM & 10:00 - 12:00 PM & 1466 \\
\hline & 491 & 12:51 - 1:13 PM & 1:00 - 2:00 PM & - \\
\hline & 492 & $1: 13-1: 34$ PM & 1:00 - 2:00 PM & - \\
\hline & 493 & $1: 34-2: 00 \mathrm{PM}$ & 1:00 - 2:00 PM & 1545 \\
\hline & 494 & $2: 57-3: 25 \mathrm{PM}$ & $3: 00-4: 00$ PM & - \\
\hline & 495 & $3: 25-3: 46$ PM & $3: 00-4: 00$ PM & - \\
\hline & 496 & $3: 46-3: 59$ PM & $3: 00-4: 00$ PM & 1173 \\
\hline & 498 & $5: 56$ - 5:56 PM & $6: 00-7: 00$ PM & - \\
\hline & 499 & $5: 56-6: 17 \mathrm{PM}$ & $6: 00-7: 00$ PM & - \\
\hline & 500 & $6: 17-6: 45$ PM & 6:00 - 7:00 PM & - \\
\hline & 501 & $6: 45-6: 58$ PM & $6: 00-7: 00$ PM & 492 \\
\hline $\begin{array}{l}\text { Saturday } \\
\text { September } 31\end{array}$ & 502 & $8: 54-9: 12$ AM & 9:00 - 12:00 PM & - \\
\hline \multirow[t]{14}{*}{ Day 10} & 503 & $9: 12$ - 9:35 AM & 9:00 - 12:00 PM & - \\
\hline & 504 & 9:35 - 9:56 AM & 9:00 - 12:00 PM & 322 \\
\hline & 505 & 9:56 - 10:16 AM & 9:00 - 12:00 PM & - \\
\hline & 506 & $10: 16-10: 39 \mathrm{AM}$ & 9:00 - 12:00 PM & - \\
\hline & 507 & $10: 39-11: 00 \mathrm{AM}$ & 9:00 - 12:00 PM & 415 \\
\hline & 508 & $11: 00-11: 22 \mathrm{AM}$ & 9:00 - 12:00 PM & - \\
\hline & 509 & $11: 22-11: 42 \mathrm{AM}$ & 9:00 - 12:00 PM & - \\
\hline & 510 & 11:42 - 12:03 PM & 9:00 - 12:00 PM & 463 \\
\hline & 511 & 1:57 - 2:17 PM & $2: 00-4: 00 \mathrm{PM}$ & - \\
\hline & 512 & $2: 17-2: 38$ PM & $2: 00-4: 00 \mathrm{PM}$ & - \\
\hline & 513 & $2: 38$ - 2:58 PM & $2: 00-4: 00$ PM & 454 \\
\hline & 514 & $2: 58-3: 20 \mathrm{PM}$ & $2: 00-4: 00 \mathrm{PM}$ & - \\
\hline & 515 & $3: 20-3: 41$ PM & $2: 00-4: 00$ PM & - \\
\hline & 516 & $3: 41$ - 3:59 PM & $2: 00-4: 00$ PM & 514 \\
\hline
\end{tabular}




\section{Appendix D: In-Depth Interviews Conducted}

\begin{tabular}{|c|c|c|c|}
\hline Name & Occupation & Role in plaza & $\begin{array}{l}\text { Date } \\
\text { Interviewed }\end{array}$ \\
\hline $\begin{array}{l}\text { Architect at } \\
\text { Nevue Ngan }\end{array}$ & $\begin{array}{l}\text { Architect at Nevue Ngan } \\
\text { Associates }\end{array}$ & $\begin{array}{l}\text { Designed Montgomery } \\
\text { green street plan, } \\
\text { stormwater retrofit of } \\
\text { plaza }\end{array}$ & $03 / 12 / 12$ \\
\hline Doug Macy & $\begin{array}{l}\text { Founding Principal } \\
\text { Architect at Walker Macy }\end{array}$ & $\begin{array}{l}\text { Original designer of } \\
\text { Urban Center Plaza }\end{array}$ & 03/06/12 \\
\hline $\begin{array}{l}\text { Nohad A. } \\
\text { Toulan }\end{array}$ & $\begin{array}{l}\text { Dean Emeritus at College } \\
\text { of Urban and Public } \\
\text { Affairs, Portland State } \\
\text { University }\end{array}$ & $\begin{array}{l}\text { Current Dean at the } \\
\text { time, led new University } \\
\text { District initiative }\end{array}$ & 03/08/12 \\
\hline $\begin{array}{l}\text { L. Rudolph } \\
\text { Barton }\end{array}$ & $\begin{array}{l}\text { Architecture Professor at } \\
\text { Portland State University }\end{array}$ & $\begin{array}{l}\text { On City Design } \\
\text { Commission at the time, } \\
\text { charged with reviewing } \\
\text { city projects }\end{array}$ & 03/09/12 \\
\hline
\end{tabular}




\section{Appendix E: In-depth Interview Questions}

Public Space and Placemaking: An Analysis of a Portland Plaza

Name:

Occupation:

Date:

1. What was your involvement in the Urban Plaza?

2. Are you still involved in the plaza in some way?

3. How do you feel about the process in retrospect?

4. Are you satisfied with the result?

5. Are there any plans to change the plaza as of now?

**Other questions may be asked based on answers or the subject's occupation and specific role in the Urban Plaza. 


\section{Appendix F: In-depth Interview Consent Form}

\section{Public Space and Placemaking: An Analysis of a Portland Plaza}

You are invited to participate in a research study conducted by Katrina Johnston from Portland State University, School of Urban Studies and Planning. The researcher hopes to learn how the Urban Plaza was created, how people use it and open space in general, and what features can be considered positive and negative aspects of public space. This research is being conducted as part of a master's thesis under the direction of Dr. Ethan Seltzer. You were selected as a possible participant in this study because you are or were involved in the creation, management, or use of the Urban Plaza.

If you decide to participate, you will be asked to take part in an interview, which involves answering questions about your role in the plaza's design or use. This can take place at any convenient place and time as you see fit and will not be audio or video recorded. It should take approximately 30 minutes to complete.

While participating in this study, it is possible that you may feel embarrassed or uncomfortable talking about your role regarding the Urban Plaza. However, I assure you that you will not be identified in any way if you wish to remain anonymous and you can stop the interview at any time or skip questions that you do not want to answer. You may not receive any direct benefit from taking part in this study, but the study may help to increase knowledge that may help others in the future including improving public space design and adding to the current body of research on the topic.

Any information that is obtained in connection with this study and that can be linked to you or identify you will be kept confidential unless explicitly stated otherwise by you below. If you wish to include your name, it will be used in the thesis and possibly a peer-reviewed article in the future only. All information will be kept confidential by keeping all transcripts locked in a secure facility on PSU's campus and by using non-identifying descriptors or phrases in the thesis or peerreviewed article.

Your participation is voluntary. Your decision to participate or not will not affect your relationship with the researcher or with Portland State University in any way. You may choose to withdraw from this study at any time without penalty.

If you have concerns or problems about your participation in this study or your rights as a research subject, please contact the Human Subjects Research Review Committee, Office of Research and Sponsored Projects, 600 Unitus Bldg., Portland State University, (503) 725-4288 / 1-877-480-4400. If you have questions about the 
study itself, contact Katrina Johnston at 2081 NW Everett St. Apt. 203, Portland, OR, 97209, (503) 899-2448 or okatrina@pdx.edu.

Your signature indicates that you have read and understand the above information and agree to take part in this study. Please understand that you may withdraw your consent at any time without penalty, and that, by signing, you are not waiving any legal claims, rights or remedies. The researcher will provide you with a copy of this form for your own records.

(Signature) (Date)

By signing this additional section you agree to including your name in the published thesis and possibly a peer-reviewed article in the future. Quotes will not be incriminating or damaging in any way and will be only applied where it is appropriate to explain where information came from. The purpose is to more thoroughly explain the story of the Urban Plaza and how it came about. Certain key players had more of an impact in the design and creation of the Urban Plaza, and may be more important to include in the research. If you had a key role, please consider including your name, but know that you are in no way obliged to include your name and will be considered confidential if you do not sign below.

(Signature) (Date) 


\section{Appendix G: Total Behavioral Counts}

\begin{tabular}{|c|c|c|c|c|c|c|c|c|c|}
\hline Date/time & Walk & Bike & WC & $\mathbf{S}$ & Run & TOTAL & Sit & Pause & Other Items* \\
\hline \multicolumn{10}{|l|}{$\begin{array}{l}\text { Tuesday, } \\
\text { September } 19\end{array}$} \\
\hline \multicolumn{10}{|l|}{ 9:00 - 10:00 PM } \\
\hline $10: 00$ - 11:00 AM & 838 & 11 & 6 & 1 & 0 & 856 & 9 & 81 & $\mathrm{C}(1)^{* *}$ \\
\hline \multicolumn{10}{|l|}{$11: 00$ - 12:00 PM } \\
\hline \multicolumn{10}{|l|}{ 12:00 - 1:00 PM } \\
\hline 1:00 - 2:00 PM & 1317 & 23 & 4 & 1 & 0 & 1345 & 87 & 189 & $\mathrm{C}(1) \mathrm{T}(2)$ [Event] \\
\hline 2:00 - 3:00 PM & 859 & 25 & 2 & 5 & 2 & 893 & 30 & 85 & SB (2) \\
\hline $3: 00$ - 4:00 PM & 822 & 19 & 5 & 0 & 1 & 847 & 23 & 46 & SB (1) \\
\hline \multicolumn{10}{|l|}{ 4:00 - 5:00 PM } \\
\hline $5: 00$ - 6:00 PM & 447 & 14 & 0 & 1 & 1 & 463 & 12 & 30 & $C(1)$ \\
\hline 6:00 - 7:00 PM & & & & & & & & & \\
\hline
\end{tabular}

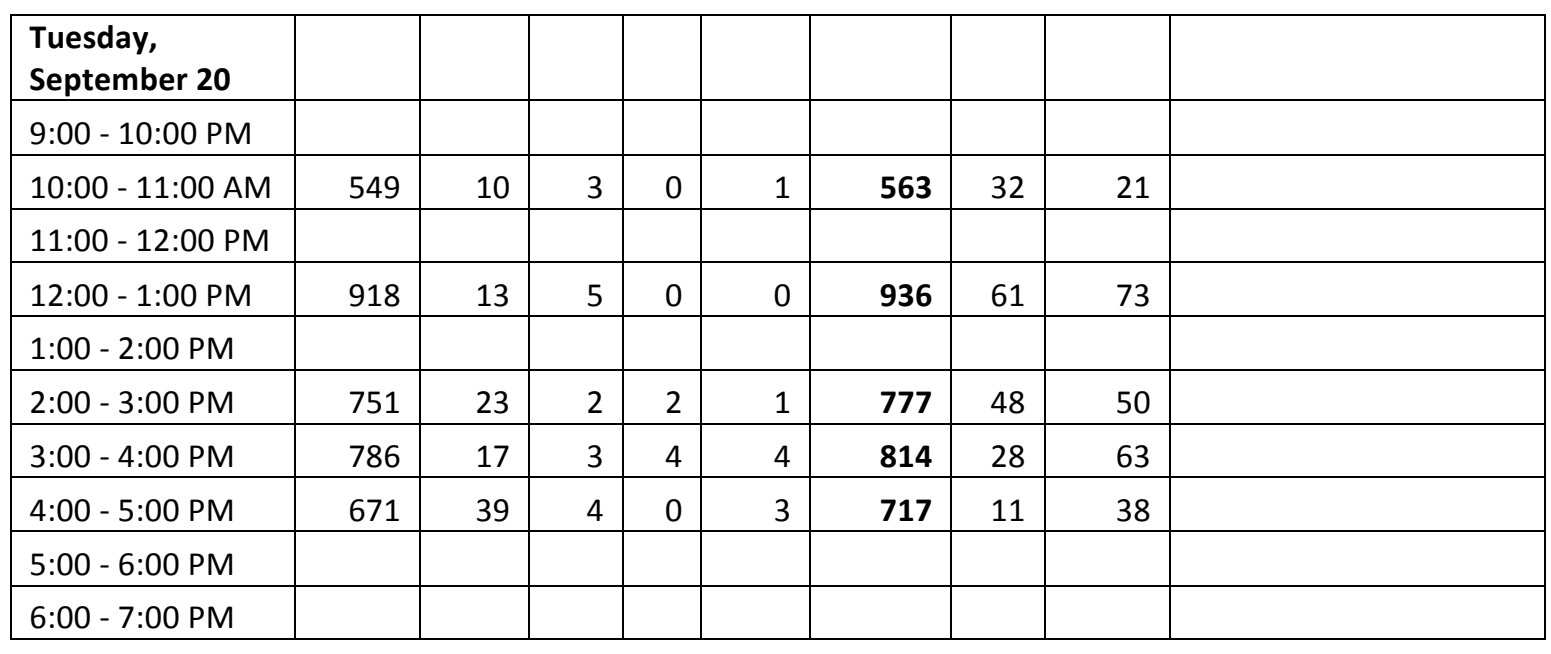

\begin{tabular}{|l|r|r|r|r|r|r|r|r|r|}
\hline $\begin{array}{l}\text { Wednesday, } \\
\text { September 21 }\end{array}$ & & & & & & & & & \\
\hline 9:00 - 10:00 PM & & & & & & & & & \\
\hline $10: 00-11: 00$ AM & 788 & 18 & 3 & 3 & 0 & 812 & 16 & 18 & SB (1), C (1) \\
\hline $11: 00-12: 00$ PM & 686 & 24 & 4 & 4 & 1 & 719 & 23 & 32 & \\
\hline $12: 00-1: 00$ PM & & & & & & & & & \\
\hline 1:00 - 2:00 PM & 878 & 24 & 3 & 6 & 1 & 909 & 57 & 104 & \\
\hline 2:00 - 3:00 PM & 877 & 42 & 5 & 2 & 10 & 934 & 49 & 71 & \\
\hline 3:00 - 4:00 PM & & & & & & & & & \\
\hline 4:00 - 5:00 PM & 673 & 43 & 2 & 3 & 1 & 722 & 33 & 44 & BC (1), SB (1) \\
\hline 5:00 - 6:00 PM & & & & & & & & & \\
\hline $6: 00-7: 00$ PM & & & & & & & & & \\
\hline
\end{tabular}




\begin{tabular}{|c|c|c|c|c|c|c|c|c|c|}
\hline $\begin{array}{l}\text { Friday, } \\
\text { September } 23\end{array}$ & & & & & & & & & \\
\hline \multicolumn{10}{|l|}{ 9:00 - 10:00 PM } \\
\hline $10: 00$ - 11:00 AM & 591 & 20 & 2 & 3 & 4 & 591 & 17 & 41 & CT (1) \\
\hline $11: 00$ - 12:00 PM & 1095 & 22 & 7 & 8 & 2 & 1134 & 54 & 87 & CT (1) \\
\hline \multicolumn{10}{|l|}{$12: 00$ - 1:00 PM } \\
\hline 1:00 - 2:00 PM & 1098 & 51 & 2 & 6 & 0 & 1157 & 74 & 110 & $C(1)$ \\
\hline 2:00 - 3:00 PM & 1030 & 32 & 6 & 3 & 0 & 1071 & 56 & 102 & SB (1) \\
\hline \multicolumn{10}{|l|}{ 3:00 - 4:00 PM } \\
\hline \multicolumn{10}{|l|}{ 4:00 - 5:00 PM } \\
\hline 5:00 - 6:00 PM & 692 & 47 & 1 & 5 & 0 & 745 & 29 & 87 & \\
\hline 6:00 - 7:00 PM & & & & & & & & & \\
\hline
\end{tabular}

\begin{tabular}{|c|c|c|c|c|c|c|c|c|c|}
\hline $\begin{array}{l}\text { Saturday, } \\
\text { September } 24\end{array}$ & & & & & & & & & \\
\hline 9:00 - 10:00 PM & 323 & 8 & 3 & 3 & 5 & 342 & 9 & 40 & $S(1)$ \\
\hline \multicolumn{10}{|l|}{$10: 00$ - 11:00 AM } \\
\hline \multicolumn{10}{|l|}{ 11:00 - 12:00 PM } \\
\hline $12: 00$ - 1:00 PM & 697 & 14 & 0 & 10 & 8 & 729 & 28 & 61 & $C(1)$ \\
\hline \multicolumn{10}{|l|}{ 1:00 - 2:00 PM } \\
\hline 2:00 - 3:00 PM & 682 & 21 & 7 & 6 & 5 & 721 & 31 & 74 & SB (9), C (1) \\
\hline \multicolumn{10}{|l|}{ 3:00 - 4:00 PM } \\
\hline 4:00 - 5:00 PM & 398 & 14 & 2 & 3 & 0 & 417 & 11 & 41 & SB (5) \\
\hline \multicolumn{10}{|l|}{$5: 00-6: 00$ PM } \\
\hline $6: 00$ - 7:00 PM & 232 & 9 & 0 & 5 & 0 & 246 & 17 & 44 & SB (1) \\
\hline
\end{tabular}

\begin{tabular}{|c|c|c|c|c|c|c|c|c|c|}
\hline $\begin{array}{l}\text { Monday, } \\
\text { September } 26\end{array}$ & & & & & & & & & \\
\hline 9:00 - 10:00 PM & 1310 & 21 & 3 & 5 & 0 & 1339 & 0 & 70 & $C(2)$ \\
\hline $10: 00-11: 00$ AM & 1750 & 37 & 4 & 1 & 0 & 1792 & 17 & 94 & $\mathrm{CT}(2), \mathrm{SB}(1)$ \\
\hline $11: 00$ - 12:00 PM & 2550 & 43 & 3 & 4 & 0 & 2600 & 61 & 189 & $\mathrm{C}(2), \mathrm{CT}(1)$ \\
\hline \multicolumn{10}{|l|}{$12: 00$ - 1:00 PM } \\
\hline 1:00 - 2:00 PM & 2415 & 35 & 4 & 1 & 0 & 2455 & 117 & 149 & CT (1) \\
\hline \multicolumn{10}{|l|}{ 2:00 - 3:00 PM } \\
\hline \multicolumn{10}{|l|}{ 3:00 - 4:00 PM } \\
\hline \multicolumn{10}{|l|}{ 4:00 - 5:00 PM } \\
\hline 5:00 - 6:00 PM & 1506 & 44 & 2 & 2 & 0 & 1554 & 54 & 123 & SB (1) \\
\hline $6: 00$ - 7:00 PM & & & & & & & & & \\
\hline
\end{tabular}




\begin{tabular}{|l|r|r|r|r|r|r|r|r|l|}
\hline $\begin{array}{l}\text { Tuesday, } \\
\text { September 27 }\end{array}$ & & & & & & & & & \\
\hline 9:00 - 10:00 AM & 1743 & 51 & 0 & 0 & 2 & $\mathbf{1 8 0 0}$ & 18 & 62 & CT (4) \\
\hline 10:00 - 11:00 AM & 1206 & 33 & 2 & 4 & 0 & $\mathbf{1 2 4 5}$ & 36 & 86 & CT (1) \\
\hline 11:00 - 12:00 PM & 1840 & 47 & 1 & 2 & 0 & $\mathbf{1 8 9 0}$ & 47 & 140 & SB (1) \\
\hline 12:00 - 1:00 PM & 1460 & 23 & 1 & 3 & 2 & 1489 & 52 & 136 & \\
\hline 1:00 - 2:00 PM & & & & & & & & & \\
\hline 2:00 - 3:00 PM & & & & & & & & & \\
\hline 3:00 - 4:00 PM & & & & & & & & & \\
\hline 4:00 - 5:00 PM & & & & & & & & & \\
\hline 5:00 - 6:00 PM & 1375 & 34 & 2 & 2 & 2 & 1415 & 43 & 98 & SB (1), W (1) \\
\hline 6:00 - 7:00 PM & & & & & & & & & \\
\hline
\end{tabular}

\begin{tabular}{|l|r|r|r|r|r|r|r|r|l|}
\hline $\begin{array}{l}\text { Thursday, } \\
\text { September 29 }\end{array}$ & & & & & & & & & \\
\hline 9:00 - 10:00 AM & & & & & & & & & \\
\hline 10:00 - 11:00 AM & & & & & & & & & \\
\hline 11:00 - 12:00 PM & 2060 & 35 & 6 & 8 & 0 & $\mathbf{2 1 0 9}$ & 69 & 58 & $\begin{array}{l}\text { T (1), S (1), SB (1), BC } \\
(1)\end{array}$ \\
\hline $12: 00-1: 00$ PM & 1816 & 37 & 4 & 4 & 0 & $\mathbf{1 8 6 1}$ & 85 & 113 & $\mathrm{~T}(1), \mathrm{S} \mathrm{(1),} \mathrm{BC} \mathrm{(2)}$ \\
\hline 1:00 - 2:00 PM & 2045 & 52 & 6 & 5 & 2 & $\mathbf{2 1 1 0}$ & 65 & 114 & $\mathrm{~T}(1), \mathrm{C}(1), \mathrm{BC}(1)$ \\
\hline 2:00 - 3:00 PM & 1344 & 34 & 0 & 0 & 3 & $\mathbf{1 3 8 4}$ & 57 & 121 & $\mathrm{SB}(3)$ \\
\hline 3:00 - 4:00 PM & 1683 & 57 & 4 & 1 & 1 & $\mathbf{1 6 8 3}$ & 62 & 124 & $\mathrm{SB}(1), \mathrm{CT}(1)$ \\
\hline 4:00 - 5:00 PM & & & & & & & & & \\
\hline 5:00 - 6:00 PM & & & & & & & & & \\
\hline 6:00 - 7:00 PM & & & & & & & & & \\
\hline
\end{tabular}

\begin{tabular}{|l|r|r|r|r|r|r|r|r|l|}
\hline $\begin{array}{l}\text { Friday } \\
\text { September 30 }\end{array}$ & & & & & & & & & \\
\hline 9:00 - 10:00 AM & & & & & & & & & \\
\hline 10:00 - 11:00 AM & 1045 & 32 & 4 & 4 & 0 & 1080 & 37 & 86 & \\
\hline $11: 00-12: 00$ PM & 1422 & 39 & 2 & 1 & 2 & 1466 & 35 & 82 & C (1), BC (1), SB (2) \\
\hline $12: 00-1: 00$ PM & & & & & & & & & \\
\hline 1:00 - 2:00 PM & 1505 & 33 & 0 & 3 & 4 & 1545 & 59 & 111 & C (1), SB (1) \\
\hline 2:00 - 3:00 PM & & & & & & & & & \\
\hline 3:00 - - 4:00 PM & 1173 & 41 & 4 & 3 & 0 & 1173 & 52 & 119 & SB (2) \\
\hline 4:00 - 5:00 PM & & & & & & & & & \\
\hline $5: 00-6: 00$ PM & & & & & & & & & \\
\hline $6: 00-7: 00$ PM & 461 & 26 & 0 & 4 & 1 & 492 & 7 & 45 & \\
\hline
\end{tabular}




\begin{tabular}{|l|r|r|r|r|r|r|r|r|l|}
\hline $\begin{array}{l}\text { Saturday } \\
\text { September 31 }\end{array}$ & & & & & & & & & \\
\hline 9:00 - 10:00 AM & 322 & 5 & 0 & 4 & 4 & $\mathbf{3 2 2}$ & 7 & 15 & \\
\hline 10:00 - 11:00 AM & 399 & 4 & 6 & 6 & 1 & $\mathbf{4 1 5}$ & 3 & 32 & \\
\hline 11:00 - 12:00 PM & 455 & 15 & 1 & 7 & 0 & 463 & 6 & 49 & \\
\hline 12:00 - 1:00 PM & & & & & & & & & \\
\hline 1:00 - 2:00 PM & & & & & & & & & \\
\hline 2:00 - 3:00 PM & 425 & 23 & 0 & 3 & 3 & 454 & 13 & 54 & SB (1) \\
\hline 3:00 - 4:00 PM & 502 & 7 & 0 & 4 & 1 & 514 & 19 & 92 & $\begin{array}{l}\text { C (2), Large group of } \\
\text { pauses ( 50) }\end{array}$ \\
\hline 4:00 - 5:00 PM & & & & & & & & & \\
\hline 5:00 - 6:00 PM & & & & & & & & & \\
\hline 6:00 - 7:00 PM & & & & & & & & & \\
\hline
\end{tabular}

*Walk = person walking, Bike = person bicycling or walking with a bike, $\mathrm{WC}=$ person in a wheel chair, $\mathrm{S}=$ person with a stroller, Run = person obviously running for recreation, Sit = person sitting, Pause $=$ person pausing for more than five seconds

${ }^{* *} \mathrm{C}=\mathrm{Car}, \mathrm{SB}=$ Skateboarder, $\mathrm{BC}=$ Bike Cart, $\mathrm{CT}=$ Cart, $\mathrm{S}=$ Scooter, $\mathrm{W}=$ Person using walker, $\mathrm{T}=$ Tent 


\section{Appendix H: Urban Center Plaza Project Report by the Portland Development Commission}

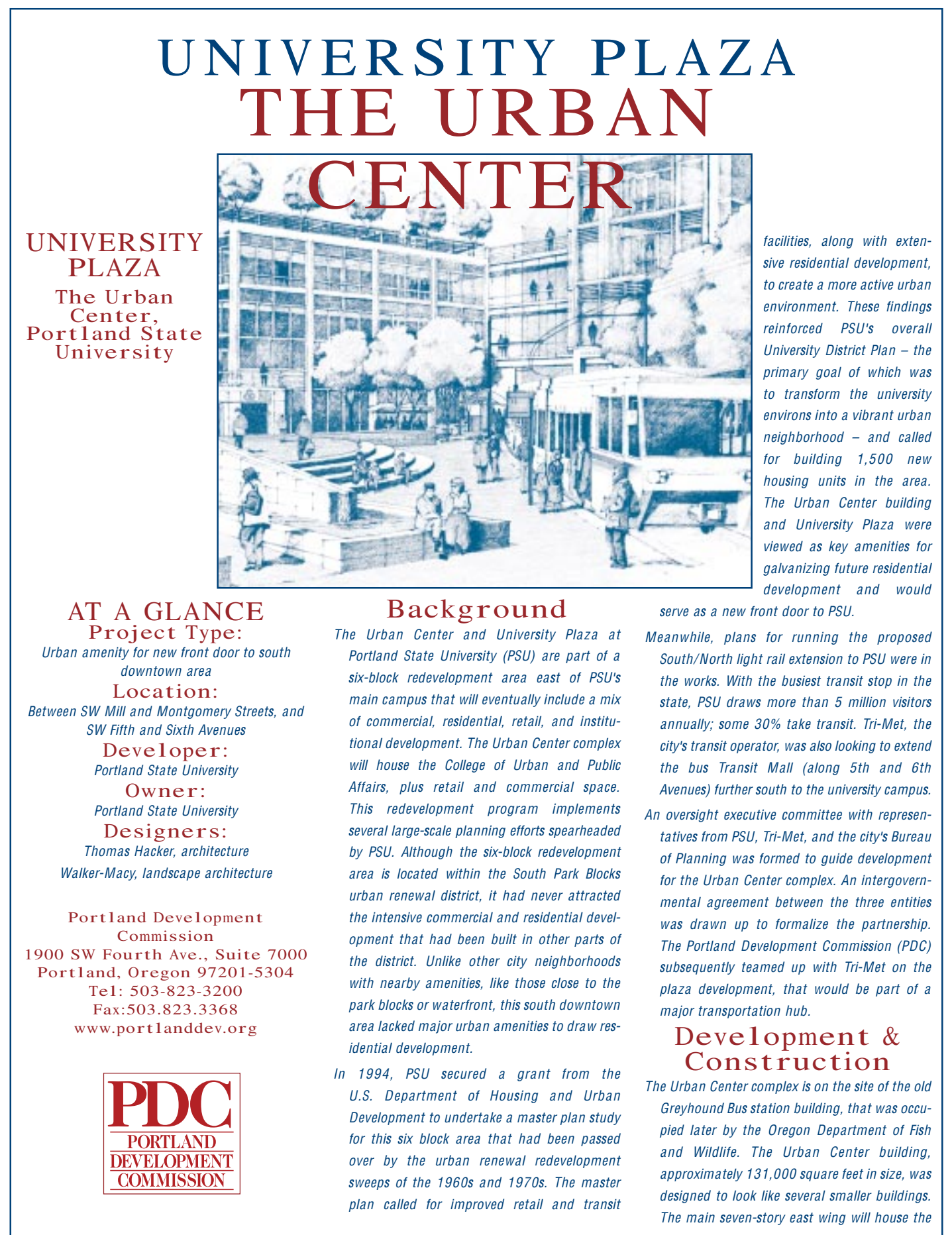


College of Urban and Public Affairs, along with the PSU bookstore on the ground floor and a number of food tenants in the basement. An information center on the ground floor, to be jointly operated by PSU and Tri-Met, will sell bus and rail passes, as well as tickets to PSU events. The Long Distance Learning Center, - a two-way audio-visual classroom that receives and sends educational programs to remote areas around the state - will be located in the three-story west wing.

Because of specific requirements of the different funding sources, the development was divided into three distinct construction projects with different contractors managing each separate piece. For example, the U.S. Department of Commerce's Economic Development Agency, which financed the Long Distance Learning Center, required that wage rates for contractors (on the west wing segment) follow federal guidelines of the Davis Bacon Act. The complex was divided into the following three construction projects: 1. east wing - College of Urban and Public Affairs; 2. west wing - Long Distance Learning Center; and 3. plaza. TriMet managed the construction of University Plaza and PDC contributed funds to the plaza construction.

Using a video camera to record the construction around the clock, PSU provided photographs of the construction site on the World Wide Web at: www.pdx.edu/urban center construction zone.

\section{Planning \& Design}

The Urban Center building/plaza complex was designed as a new front door to PSU. Thus, the decisions to locate the university book store and information center within the complex were made partly to call attention to PSU so the university would be more visible in south downtown. The roughly 30,000-square-foot plaza is comparable in size to Downtown Portland's Pioneer Courthouse Square; but the two plazas function very differently. Pioneer Courthouse Square, a popular site for large performances and cultural events, is a regional destination place. The University Plaza space is less monolithic and was designed as a central gathering place for the neighborhood.

The project architects envision the plaza as a "crucible of churning activity." The open-air farmers' market will probably move from downtown's South Park Blocks to University Plaza. The plaza area, which is located on Montgomery Street - a main pedestrian pathway that connects the waterfront to the park blocks - will also function as a major transit hub. Many people will cross the plaza on their way to and from downtown or to catch the bus on the transit mall.

Transportation issues drove the initial plaza design. Tri-Met engineers had aligned the proposed South/North light rail extension diagonally through the Urban Center site. This diagonal rail alignment inspired the circular plaza design, which involved closing a section of Montgomery Street. Although voters defeated the light rail extension in 1998, plans are now being considered to build a streetcar line that would follow the same diagonal alignment through the plaza. The plaza will function as the southern terminus of the Transit Mall that will extend to the PSU campus.

City planning policy supports Portland's tight street grid and discourages superblocks. Thus, staff with the city's Bureau of Planning initially challenged the concept of closing Montgomery Street to create the plaza. Plaza designers surmounted this objection by showing that the plaza would invite pedestrian circulation and would function as a public open space; not as a private enclave for the university community.

Relating the building design to the plaza was an additional design challenge. As viewed from the street, the Urban Center building with its formal brick facade built out to the property line, blends in with the surrounding campus buildings. On the facade that faces the plaza, the architects designed oversized windows so the building appears more transparent, less massive and, consequently, more open and inviting. This transparent design, that exposes the internal building structure, makes it easy to "read" the building from the outside. Individuals standing in the plaza can see the locations for the stairwell and elevator and thus know where to go before entering the building.

\section{Art Program}

A 15-member art advisory committee was assembled to select artwork for University Plaza. A hefty budget of $\$ 225,000$ - the city's largest public art commission since Raymond Kaskey's sculpture "Portlandia" on the Portland Building - drew more than 150 submissions. The winning design by London-based sculptor John Aiken consists of two large granite sculptures that cast a series of smaller shadow sculptures imbedded flat in the pavement. The five or six elliptical-shaped shadows in textured granite will be sprinkled throughout the plaza. The large sculptures - rugged and irregular - evoke the hills and jagged mountains of the Oregon landscape in contrast to the controlled precision of the cityscape.

Primary Funding

Sources for University Plaza:

Portland Development Commission

Federal Transit Administration

Tri-Met

The total cost for the plaza design and construction was $\$ 5$ million.

Experience Gained

The series of partnerships and different funding sources complicated the project and lengthened the development/construction process. At the same time, these partnerships brought access to other funding sources that, otherwise, might not have been available. For example, Tri-Met's involvement in developing the plaza as well as the Transit Mall extension brought access to funding from the Federal Transit Administration (FTA). FTA is funding much of the costs for construction of the plaza and also paying for streetfront improvements associated with the Transit Mall extension - ornamental lighting and street furniture, for example.

Planning on a broad, comprehensive scale empowered PSU staff to achieve specific goals on a smaller scale. The plaza element in this south section of downtown had not been envisioned in earlier planning documents, like the 1972 Downtown Plan or 1988 Central City Plan. Moreover, Portland planning policy has long discouraged superblocks, that tend to disrupt the city's 200-foot-long-block grid. To support the plaza concept, PSU planning staff looked to the earlier masterplan study they had undertaken for the six-block area surrounding the urban complex. The study recommended creating open space urban amenities to spur residential development in the area. PSU planners also showed that University Plaza - which would provide a new gateway to south downtown - would complement emerging development activity in the River District and Union Station, the downtown's new north gateway.

\section{Schedule}

Planning started: $\quad 1995$

RFQ issued: $\quad 1996$

Construction started:

June, 1998

Construction completed: 